ENVIRONMENTAL RESTORATION PROGRAM

\section{Baseline and Postremediation Monitoring Program Plan for the Lower East Fork Poplar Creek Operable Unit, Oak Ridge, Tennessee}

This document has been approved for release to the public by the Y-12 PlannTechtojal Information Office. Date: $4 \longdiv { 4 1 9 6 }$ 


\section{Science Applications International Corporation}

contributed to the preparation of this document and should not be considered an eligible contractor for its review.

This report has been reproduced directly from the best available copy.

Available to DOE and DOE contractors from the Office of Scientific and Technical Information, P.O. Box 62, Oak Ridge, TN 37831; prices available from 423-576-8401 (fax 423-576-2865).

Available to the public from the National Technical Information Service, U.S. Department of Commerce, 5285 Port Royal Rd., Springfield, VA 22161. 
Energy Systems Environmental Restoration Program

Baseline and Postremediation Monitoring Program Plan for the Lower East Fork

Poplar Creek Operable Unit, Oak Ridge, Tennessee

Date Issued-April 1996

Prepared by

Science Applications International Corporation

Oak Ridge, Tennessee

under subcontract 43B-99069C, Y05

Prepared for the

U.S. Department of Energy

Office of Environmental Management

under budget and reporting code EW 20

Environmental Management Activities at the

OAK RIDGE Y-12 PLANT

Oak Ridge, Tennessee 37831-8169

managed by

LOCKHEED MARTIN ENERGY SYSTEMS, INC.

for the

U.S. DEPARTMENT OF ENERGY

under contract DE-AC05-84OR21400 



\section{DISCLAIMER}

Portions of this document may be illegible in electronic image products. Images are produced from the best available original document. 


\section{DISCLAIMER}

This report was prepared as an account of work sponsored by an agency of the United States Government. Neither the United States Government nor any agency thereof, nor any of their employees, makes any warranty, express or implied, or assumes any legal liability or responsibility for the accuracy, completeness, or usefulness of any information, apparatus, product, or process disclosed, or represents that its use would not infringe privately owned rights. Reference herein to any specific commercial product, process, or service by trade name, trademark, manufacturer, or otherwise does not necessarily constitute or imply its endorsement, recommendation, or favoring by the United States Government or any agency thereof. The views and opinions of authors expressed herein do not necessarily state or reflect those of the United States Government or any agency thereof. 



\section{PREFACE}

This Baseline and Postremediation Monitoring Program Plan for the Lower East Fork Poplar Creek Operable Unit, Oak Ridge, Tennessee (Y/ER-262) was prepared in accordance with requirements under the Comprehensive Environmental Response, Compensation, and Liability Act (CERCLA) to present the plan for baseline and postremediation monitoring as part of the selected remedy. This work was performed under Work Breakdown Structure 1.4.12.3.1.04, Activity Data Sheet 9304, "Lower East Fork Poplar Creek." This document provides the Environmental Restoration Program with information about the requirements to monitor for soil and terrestrial biota in the Lower East Fork Poplar Creek (LEFPC) floodplain; sediment, surface water, and aquatic biota in LEFPC; wetland restoration in the LEFPC floodplain; and human use of shallow groundwater wells in the LEFPC floodplain for drinking water. This document describes the monitoring program that will ensure that actions taken under Phases I and II of the LEFPC remedial action are protective of human health and the environment. 



\section{CONTENTS}

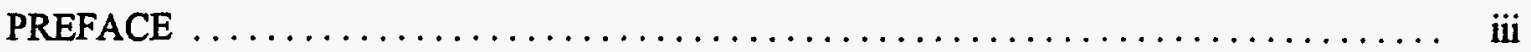

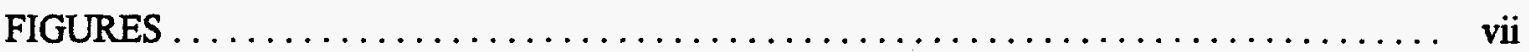

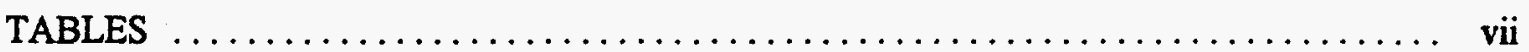

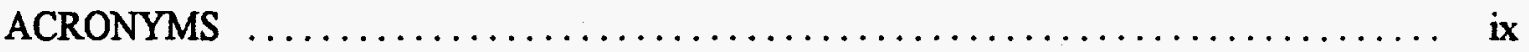

EXECUTIVE SUMMARY $\ldots \ldots \ldots \ldots \ldots \ldots \ldots \ldots \ldots \ldots \ldots \ldots \ldots \ldots \ldots \ldots \ldots \ldots \ldots$

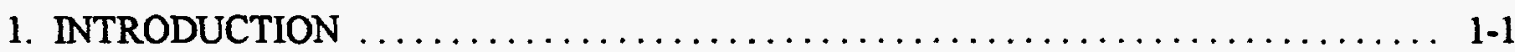

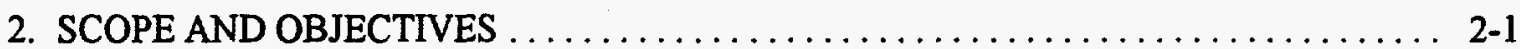

2.1 SCOPE-BOUNDARIES OF MONITORING PROGRAM $\ldots \ldots \ldots \ldots \ldots \ldots \ldots$ 2-1

2.2 OBJECTIVES-MONITORING COMPLIANCE WITH ROD $\ldots \ldots \ldots \ldots \ldots \ldots 2-2$

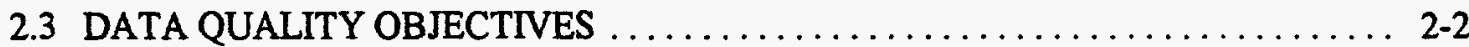

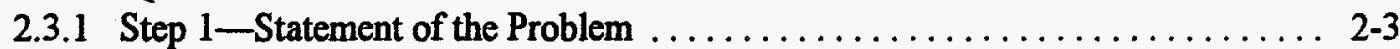

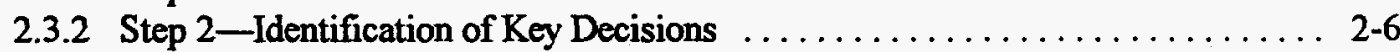

2.3.3 Step 3-Identification of Key Environmental VariablesRationale for Monitoring to Confirm Compliance .......... 2-7

2.3.4 Step 4-Identification of Spatial/Temporal Boundaries

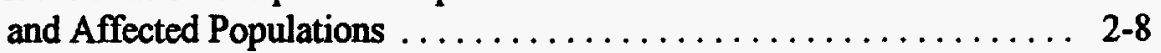

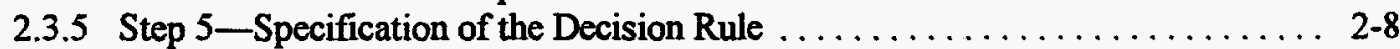

2.3.6 Step 6 -Specification of Tolerance for Uncertainty $\ldots \ldots \ldots \ldots \ldots \ldots \ldots \ldots$

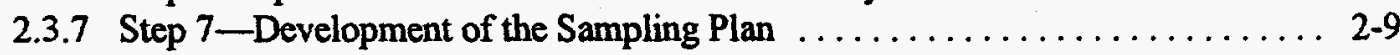

3. SETTING, CONCEPTUAL MODELS, REMEDIAL GOAL OBJECTIVES, AND COORDINATION WITH Y-12 PLANT BMAP $\ldots \ldots \ldots \ldots \ldots \ldots \ldots \ldots \ldots \ldots \ldots$

3.1 THE CERCLA REMEDIATION PROCESS $\ldots \ldots \ldots \ldots \ldots \ldots \ldots \ldots \ldots \ldots \ldots \ldots \ldots \ldots$

3.1.1 Federal Facility Agreement for the Oak Ridge Reservation ............ 3-1

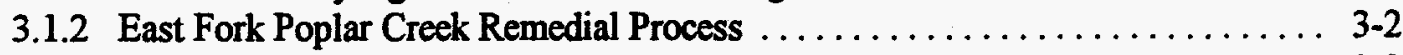

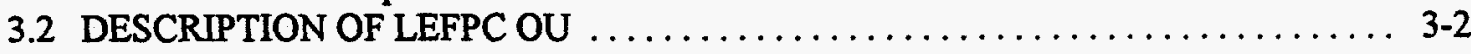

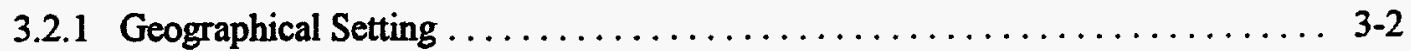

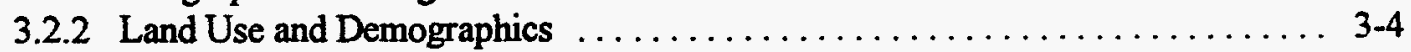

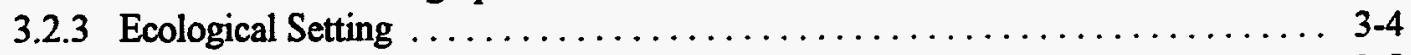

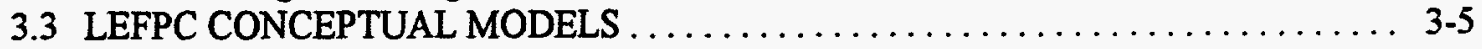

3.3.1 Conceptual Model of Mercury Dynamics $\ldots \ldots \ldots \ldots \ldots \ldots \ldots \ldots \ldots \ldots \ldots \ldots$

3.3.2 Conceptual Model of Soil and Associated Biota $\ldots \ldots \ldots \ldots \ldots \ldots \ldots \ldots$ 3-7

3.3.3 Conceptual Model of Water, Sediment, and

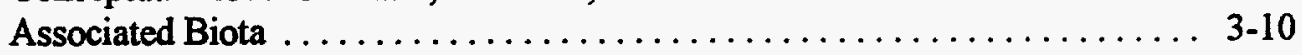

3.3.4 Conceptual Model of Human Exposure ................... 3-15

3.4 DESCRIPTION OF SOIL AND SEDIMENT RGOs $\ldots \ldots \ldots \ldots \ldots \ldots \ldots \ldots \ldots$. $3-15$

3.4.1 Remedial Goal Options ............................. 3-15

3.4.2 Key Uncertainties in Model Assumptions $\ldots \ldots \ldots \ldots \ldots \ldots \ldots \ldots \ldots \ldots \ldots$ 3-18

3.5 COORDINATION WITH Y-12 PLANT BMAP $\ldots \ldots \ldots \ldots \ldots \ldots \ldots \ldots \ldots \ldots \ldots$ 
3.5.1 Scope of the Y-12 Plant BMAP $\ldots \ldots \ldots \ldots \ldots \ldots \ldots \ldots \ldots \ldots \ldots \ldots, 3-20$

3.5.2 Compatibility of Sampling Locations $\ldots \ldots \ldots \ldots \ldots \ldots \ldots \ldots \ldots \ldots \ldots \ldots \ldots, \quad 3-21$

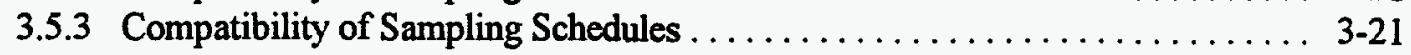

3.5.4 Use of Y-12 Plant BMAP Data in the Remedial Monitoring Process ....... 3-22

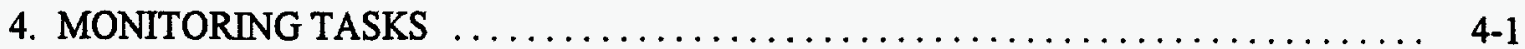

4.1 MONITORING SOIL AND ASSOCIATED BIOTA $\ldots \ldots \ldots \ldots \ldots \ldots \ldots, 4-1$

4.1.1 Monitoring Rationale $\ldots \ldots \ldots \ldots \ldots \ldots \ldots \ldots \ldots \ldots \ldots \ldots \ldots \ldots \ldots \ldots, 4,1$

4.1.2 Monitoring Endpoint Organisms $\ldots \ldots \ldots \ldots \ldots \ldots \ldots \ldots \ldots \ldots, 4.5$

4.1.3 Monitoring Locations $\ldots \ldots \ldots \ldots \ldots \ldots \ldots \ldots \ldots \ldots \ldots \ldots \ldots, \quad 4,6$

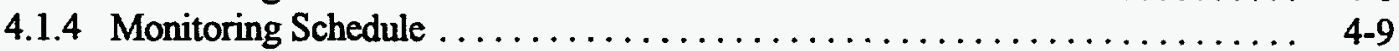

4.1.5 Sampling and Analytical Methods $\ldots \ldots \ldots \ldots \ldots \ldots \ldots \ldots \ldots \ldots \ldots, 4,9$

4.1.6 Decision Rules ................................. 4-10

4.2 MONITORING SEDIMENT, SURFACE WATER, AND FISH $\ldots \ldots \ldots \ldots \ldots$ 4-11

4.2.1 Monitoring Rationale $\ldots \ldots \ldots \ldots \ldots \ldots \ldots \ldots \ldots \ldots \ldots \ldots \ldots, 4,11$

4.2.2 Monitoring Endpoint Organisms $\ldots \ldots \ldots \ldots \ldots \ldots \ldots \ldots \ldots \ldots \ldots \ldots \ldots \ldots, 4-16$

4.2.3 Monitoring Locations $\ldots \ldots \ldots \ldots \ldots \ldots \ldots \ldots \ldots \ldots \ldots \ldots \ldots \ldots \ldots, 4,17$

4.2.4 Monitoring Schedule $\ldots \ldots \ldots \ldots \ldots \ldots \ldots \ldots \ldots \ldots \ldots \ldots, 4,18$

4.2.5 Sampling and Analytical Methods $\ldots \ldots \ldots \ldots \ldots \ldots \ldots \ldots \ldots \ldots, 4-18$

4.2.6 Decision Rules ..................................... 4-21

4.3 MONITORING WETLANDS RESTORATION $\ldots \ldots \ldots \ldots \ldots \ldots \ldots \ldots \ldots, 4-22$

4.3.1 Monitoring Rationale $\ldots \ldots \ldots \ldots \ldots \ldots \ldots \ldots \ldots \ldots \ldots, 4,23$

4.3.2 Monitoring Endpoint Entities $\ldots \ldots \ldots \ldots \ldots \ldots \ldots \ldots \ldots \ldots \ldots \ldots \ldots \ldots, \quad 4.24$

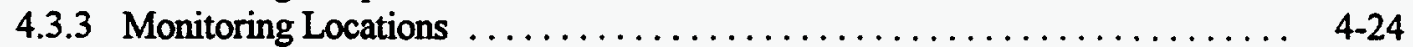

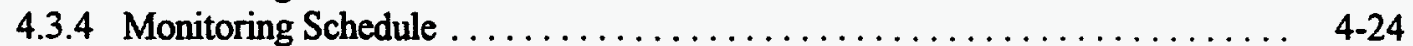

4.3.5 Wetland Evaluation Methods $\ldots \ldots \ldots \ldots \ldots \ldots \ldots \ldots \ldots \ldots \ldots, 4-24$

4.3.6 Decision Rules ..................................... 4-25

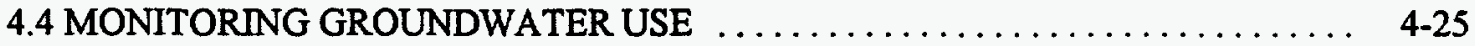

4.4.1 Monitoring Rationale $\ldots \ldots \ldots \ldots \ldots \ldots \ldots \ldots \ldots \ldots \ldots \ldots \ldots \ldots \ldots, 4,25$

4.4.2 Monitoring Endpoint Entities $\ldots \ldots \ldots \ldots \ldots \ldots \ldots \ldots \ldots \ldots \ldots \ldots \ldots, \quad 4,25$

4.4.3 Monitoring Locations $\ldots \ldots \ldots \ldots \ldots \ldots \ldots \ldots \ldots \ldots \ldots \ldots \ldots \ldots \ldots, \quad 4,25$

4.4.4 Monitoring Schedule $\ldots \ldots \ldots \ldots \ldots \ldots \ldots \ldots \ldots \ldots \ldots \ldots \ldots, 4,25$

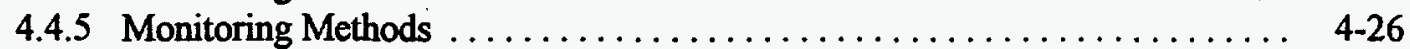

4.4.6 Decision Rules ........................................ 4-26

4.5 SUMMARY OF DECISION RULES $\ldots \ldots \ldots \ldots \ldots \ldots \ldots \ldots \ldots \ldots \ldots \ldots, 4-26$

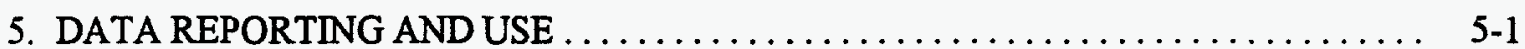

5.1 REPORTING SCHEDULE AND FORMAT $\ldots \ldots \ldots \ldots \ldots \ldots \ldots \ldots \ldots \ldots, 5-1$

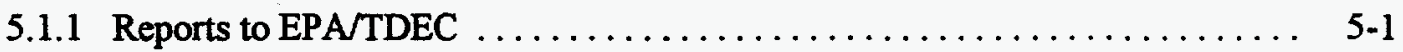

5.1.2 ORR Annual Surveillance Report ................................ 5-1

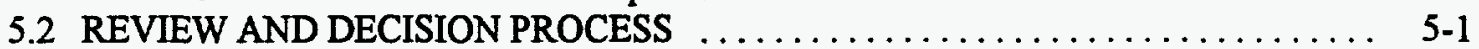

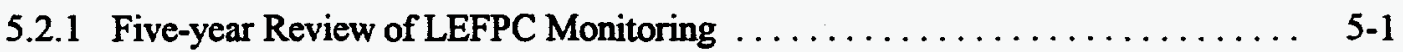

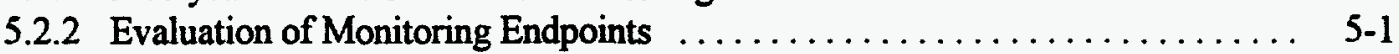

5.2 .3 Modification of Monitoring Plan $\ldots \ldots \ldots \ldots \ldots \ldots \ldots \ldots \ldots \ldots \ldots, 5-2$

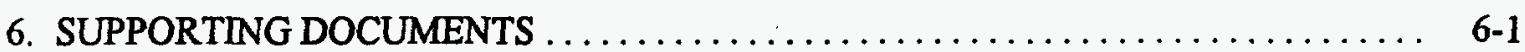

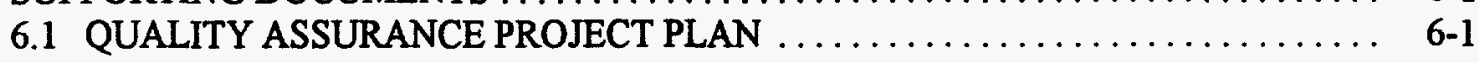

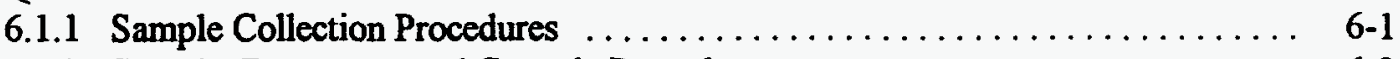

6.1.2 Sample, Document, and Custody Procedures .................. 6-2 
6.1.3 Analytical Methods ............................ $6-2$

6.1.4 Quality Control Sample Checks .......................... 6-2

6.1.5 Project Data Quality Assessment . . . . . . . . . . . . . . . . . . . . . 6-2

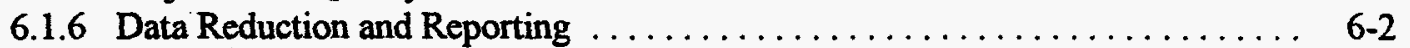

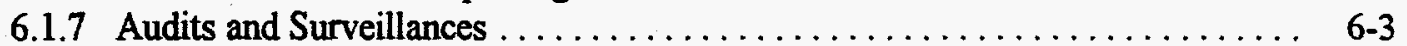

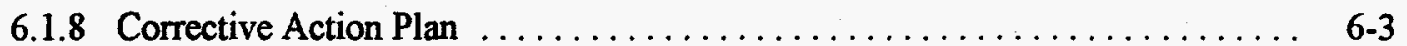

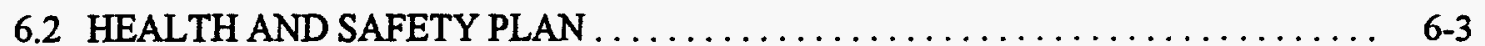

6.3 WASTE MANAGEMENT PLAN $\ldots \ldots \ldots \ldots \ldots \ldots \ldots \ldots \ldots \ldots \ldots \ldots \ldots \ldots \ldots$

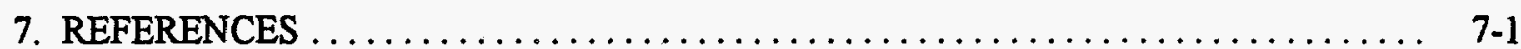





\section{FIGURES}

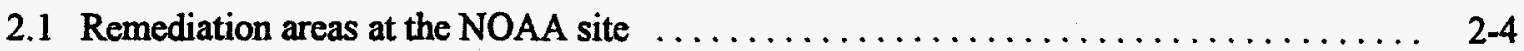

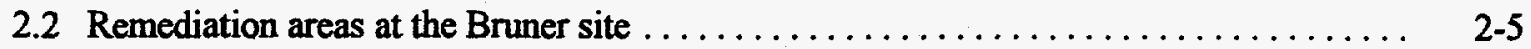

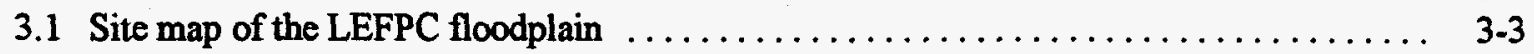

3.2 Jurisdictional wetlands in the LEFPC floodplain $\ldots \ldots \ldots \ldots \ldots \ldots \ldots \ldots \ldots \ldots \ldots$

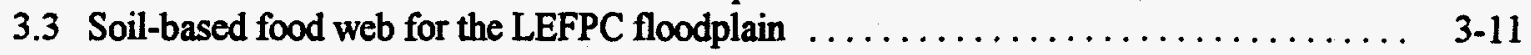

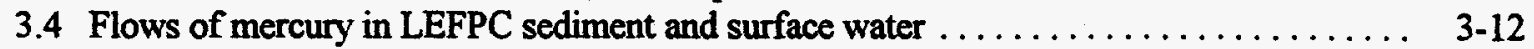

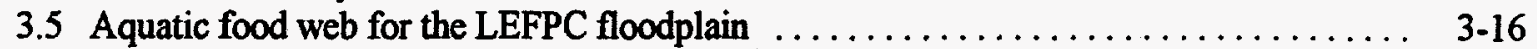

4.1 LEFPC monitoring and BMAP sampling sites $\ldots \ldots \ldots \ldots \ldots \ldots \ldots \ldots \ldots \ldots \ldots \ldots$

\section{TABLES}

4.1 Selection specifications and recommendations for monitoring of soil and soil-exposed organisms

4.2 Terrestrial sampling locations and numbers of samples for BMAP and PMP

4.3 Selection specifications and recommendations for monitoring of sediment, surface water, and fish

4.4 Sediment and aquatic sampling locations and numbers of samples for BMAP and PMP

4.5 Total mercury and methylmercury analyses for LEFPC PMP surface water and sediment samples

4.6 Decision rules and data required for decisions 



\section{ABBREVIATIONS}

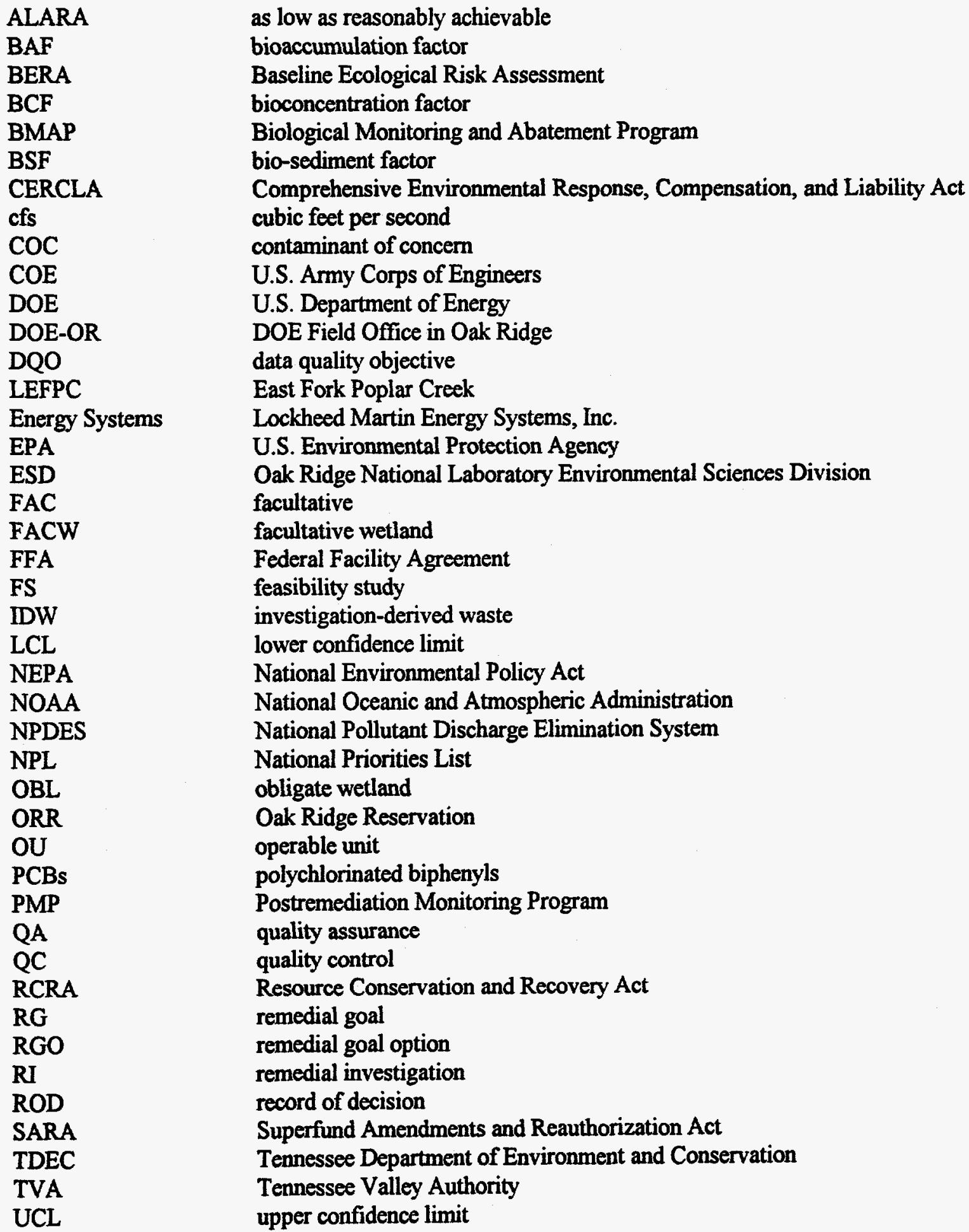





\section{EXECUTIVE SUMMARY}

The overall purpose of the Lower East Fork Poplar Creek (EFPC) Baseline and Postremediation Monitoring Program (PMP) Plan is to confirm that remedial actions comply with the EFPC Record of Decision (ROD), which specifies that those actions will be protective of human health and the environment, i.e., plant and animal populations [U.S. Department of Energy (DOE) 19956]. The PMP does not include sampling during remedial action construction. Rather, it deals with sampling before (baseline) and after (postremediation monitoring) construction has been completed. It is the intent of the PMP to use data from the Y-12 Plant Biological Monitoring and Abatement Program (BMAP) to evaluate compliance with the ROD as economically as possible.

Under the ROD, areas of the EFPC floodplain where soil is contaminated with $>400 \mathrm{mg}$ mercury $/ \mathrm{kg}$ will be excavated, and the soil will be replaced with clean soil. A small area of wetland will be reconstructed. No remediation of surface water, sediment, or groundwater is planned. Although the ROD states that the selected remedy is protective of human health and the environment, there is uncertainty about the extent of residual risks to plant and animal populations after excavation and site restoration have been completed. Therefore, the ROD calls for appropriate monitoring of EFPC floodplain soils and associated biota and of EFPC surface water, sediments, and associated biota. Also, potential risk from human consumption of groundwater in the EFPC floodplain has been identified, and the ROD requires monitoring for groundwater use as drinking water.

Baseline and postremediation monitoring will address the following issues:

- Several soil remedial goal options (RGOs) were proposed during the RI process that would be protective of ecological populations. Monitoring will provide data to evaluate whether populations are protected when mercury concentrations in soil remain above the ecological soil RGO of 200 $\mathrm{mg} / \mathrm{kg}$, as well as when mercury concentrations are between $50 \mathrm{mg} / \mathrm{kg}$ and $200 \mathrm{mg} / \mathrm{kg}$.

- Residual soil mercury could potentially contaminate EFPC surface water and sediment. Monitoring will determine whether surface water and sediment mercury concentrations remain nontoxic to aquatic and sediment-dwelling biota.

- Health risk from drinking groundwater from the shallow water table was demonstrated in the remedial investigation (RI). Because there is currently no use of drinking water from that source, there will be no remediation of groundwater or most of the soil. However, potential exposure to groundwater will remain. Surveillance will determine whether there is a potential for ingestion exposure to groundwater by identifying use of groundwater wells.

- Wetlands will be excavated and reconstructed during remediation. Monitoring will determine whether wetland function has been restored in the reconstructed wetlands.

The Y-12 Plant BMAP is a good source of information about exposure to and effects of contaminants in aquatic biota in Lower EFPC. Much of the information from the BMAP investigations is compatible with the objectives and intended uses of the EFPC PMP. Therefore, information from the BMAP investigations will be incorporated into the PMP as fully as possible. Further, the PMP and BMAP are intended to overlap a great deal. This serves to optimize the time, money, and talent required 
for monitoring. Exposures of terrestrial biota to soil contaminants will be evaluated by sampling and analyses that are specific to the PMP but will be carried out by BMAP personnel.

BMAP biological monitoring is being done at several sites in Lower EFPC, including five sites for contaminant bioaccumulation (EFPC km 23.4, 18.2, 13.8, 6.3, and 2.1) and six sites for ambient toxicity monitoring (EFPC $\mathrm{km} \mathrm{22.8,} \mathrm{21.9,} \mathrm{20.5,} \mathrm{18.2,} \mathrm{13.8,} \mathrm{and} \mathrm{10.9).} \mathrm{Four} \mathrm{locations} \mathrm{on} \mathrm{the} \mathrm{EFPC} \mathrm{floodplain}$ will be used for the EFPC soil monitoring program. Two sites, the National Oceanic and Atmospheric Administration (NOAA) site and the Bruner site, have soil mercury concentrations above $400 \mathrm{mg} / \mathrm{kg}$ and will be remediated. They are located, respectively, near EFK 21.9 and EFK 17.5. A site on the Jackson farm has maximum levels of mercury in soil below the ecological remedial goal (RG), between $50 \mathrm{mg} / \mathrm{kg}$ and $200 \mathrm{mg} / \mathrm{kg}$. A field near the Grand Cove subdivision has maximum soil mercury concentrations above $200 \mathrm{mg} / \mathrm{kg}$.

Remediation of the two EFPC locations with $>400 \mathrm{mg} / \mathrm{kg}$ (NOAA site and Bruner site) will reduce mercury concentrations below those that cause unacceptable risk to humans. Further monitoring will not be required for human health. Remediation will also decrease the risk to ecological receptors exposed to soil mercury at these two sites. Monitoring of these two sites will allow evaluation of the protectiveness of remediation and possible unexpected effects of soil removal and revegetation on ecological receptors.

Monitoring sites with soil mercury up to $400 \mathrm{mg} / \mathrm{kg}$ (Jackson farm and Grandcove Estates) will allow evaluation of the protectiveness of leaving these soils unremediated. The chosen remedial goal option (RGO) for protection of ecological receptors from mercury in soil is $200 \mathrm{mg} / \mathrm{kg}$ total mercury (DOE 1994b), although $500 \mathrm{mg} / \mathrm{kg}$ total mercury in soil is predicted to protect populations of the most at-risk ecological receptors, mid-level predators exposed to mercury in soil from ingesting soil-dwelling invertebrates (DOE 1995b).

The measurement endpoints for the EFPC soil monitoring program will provide data for the evaluation of the monitoring endpoints and will allow the objectives of the PMP to be met for EFPC soil and associated biota. The measurement endpoints are:

- Measurement endpoint 1: the concentrations of total mercury and methylmercury in composite samples of earthworms from the EFPC floodplain.

- Measurement endpoint 2: the concentrations of total mercury and methylmercury in samples of individual starling nestlings obtaining their diet predominantly from the EFPC floodplain.

- Measurement endpoint 3: fertility and viability of starlings reared on the EFPC floodplain relative to a reference site.

- Measurement endpoint 4: (conditional): if earthworm populations decline to the extent that insufficient individuals can be collected for Measurement endpoint 1, then the toxicity of EFPC floodplain soil to earthworms relative to a reference site and relative to a laboratory control will be evaluated.

To evaluate the effects of soil mercury on terrestrial biota, starling nest boxes will be installed at four study areas and one reference area. Samples of soil will be collected and analyzed for total mercury and methylmercury at the time of installation. Earthworms and starling nestlings will be sampled annually 
and analyzed for total mercury and methylmercury, and reproductive success of starlings will be measured. Body burdens of earthworms will be compared to dietary toxicity benchmarks for starlings, and body burdens in starlings will be compared to dietary toxicity benchmarks for top predators.

The measurement endpoints for the EFPC sediment and surface water monitoring program are direct or indirect indicators of increased exposure to and adverse effects on sediment-dwelling organisms, aquatic biota, and piscivorous predators from mercury in EFPC sediment and surface water. The measurement endpoints are:

- Measurement endpoint 5: the concentrations of total mercury and methylmercury in composite samples of species of fish that are eaten by piscivorous predators.

- Measurement endpoint 6: the toxicity of EFPC sediment to sediment-dwelling organisms relative to sediments from a reference site and relative to a laboratory control.

- Measurement endpoint 7: the toxicity of EFPC surface water to aquatic biota relative to surface water from a reference site and relative to a laboratory control.

- Measurement endpoint 8: the concentrations of total mercury and methylmercury in surface water.

For the PMP, redbreast sunfish, striped shiners, and central stonerollers will be sampled at four of the sites established by BMAP (EFK 23.4, EFK 18.2, EFK 13.8, and a reference site). Sunfish will be analyzed for total mercury in fillets twice annually at most sites; on two occasions, sunfish will be analyzed for total mercury and methylmercury in both fillets and whole bodies. As a measure of trophic transfer from sediment, striped shiners and stonerollers will be analyzed for total mercury and methylmercury on an annual basis. These fish will be sampled at EFK 23.4, EFK 18.2, EFK 13.8, and a reference site.

Sediment will be sampled twice annually and analyzed for total mercury and methylmercury and for toxicity to Hyalella azteca (a freshwater scud). Sediment will be sampled at or near EFK 22.6 and EFK 21.6 (NOAA site), EFK 17.9 and EFK 17.0 (Bruner site), EFK 14.3 (Jackson farm), EFK 10.0 (Grandcove Estates), and a reference site. Surface water will be sampled twice annually and analyzed for total mercury and methylmercury and for toxicity to Ceriodaphnia dubia. Surface water toxicity tests will be conducted at EFK 22.8, EFK 21.9, EFK 18.2, EFK 17.0, EFK 13.8, EFK 10.9, and a reference site.

The monitoring endpoints for wetlands restoration are: the presence of hydrophytic vegetation, presence of water-saturated soil for a significant portion of the growing season (to represent hydric soils), and presence of enough water to saturate or inundate the site for the minimum critical period to establish wetland hydrology, as specified in the mitigation plan (at a minimum 10 to 14 days of continuous saturation or inundation). Measurement endpoints for wetlands are:

- Measurement endpoint 9: the abundance, frequency, and distribution of facultative and obligate wetland plant species in the restored or constructed wetland.

- Measurement endpoint 10: the duration of soil saturation or inundation at the site during the local growing season. 
The reconstructed wetland at the Bruner site will be inspected annually to evaluate the success of wetland construction.

Monitoring for groundwater use will identify potential new groundwater wells in the shallow water table of the EFPC floodplain and allow for mitigation of their use as drinking water. An annual surveillance of the floodplain will be carried out by visual inspection. If it is concluded that a well might have been installed, that information will be given to DOE. DOE will contact the landowner to determine whether groundwater use is occurring, and, if so, what mitigative measures to take.

Sampling of earthworms and starlings will be done in the spring and summer, while the broods of starlings are being reared. Sampling activities for sediment, sediment-associated biota, surface water, and aquatic biota for the EFPC PMP will be conducted to complement, wherever possible, the BMAP sampling schedule. Semiannual sampling in late fall and spring, which is when the BMAP ecological surveys are performed, would be consistent with the goals of the PMP. Wetland inspections will be done during the growing season to ensure that the saturation criterion can be evaluated. Annual surveillance for groundwater use will be done during warm weather.

Data will be reported in the Oak Ridge Reservation Annual Surveillance Report and in a five-year review. If the evaluation of monitoring data indicates that there has been an increase in the exposure of and effects on monitoring endpoint organisms due to mercury in the EFPC environment, then the risk to ecological receptors would need to be evaluated in accordance with the EFPC Baseline Ecological Risk Assessment (BERA) assessment endpoints. The level of adverse effects estimated from the predicted or measured exposure of ecological receptors to mercury will be compared to the level of protection specified in the BERA assessment endpoints, and a decision will be made as to whether the remedial plan for Lower EFPC is protective or needs to be revised.

A comparison of monitoring results to assessment endpoints may show that some endpoints are being met, whereas others are not. If it is clear that a assessment endpoint is being met and there is no trend suggesting that it may not be met in the future, the intensity of monitoring for that endpoint could be reduced. Instead, a greater number of samples could be taken to clarify that another endpoint is not being met or to fill data gaps identified by evaluation of the results. If review of the monitoring data reveals data gaps not foreseen in this plan, the plan should be revised to collect the necessary additional data. Modification of the monitoring plan should be done in consultation with DOE, the U.S. Environmental Protection Agency (EPA), and the Tennessee Department of Environment and Conservation. 


\section{INTRODUCTION}

Lower East Fork Poplar Creek (EFPC) and its floodplain have been the subject of a remedial investigation (RI) and feasibility study (FS) that have culminated in a record of decision (ROD), which was signed August 18, 1995. Under the ROD, areas of the EFPC floodplain where there is soil contaminated with $>400 \mathrm{mg}$ mercury $/ \mathrm{kg}$ will be excavated, and the soil will be replaced with clean soil. No remediation of surface water, sediment, or groundwater is planned. The ROD states that if the response action selected in the ROD is not implemented, hazardous substances at the site present an unacceptable risk to public health, welfare, and the environment. Although the ROD states that the selected remedy is protective of human health and the environment, there is uncertainty about the extent of residual risks to plant and animal populations after implementation of the proposed plan. Therefore, the ROD calls for appropriate monitoring of EFPC floodplain soils and associated biota and of EFPC surface water, sediments, and associated biota.

The EFPC Postremediation Monitoring Program (PMP) is being established to comply with the ROD. The Y-12 Plant Biological Monitoring and Abatement Program (BMAP) was developed to comply with requirements of a 1985 National Pollutant Discharge Elimination System (NPDES) permit (Loar et al. 1989) to monitor the effects of water-borne contaminants released from the Y-12 Plant on aquatic biota in EFPC and by itself does not meet all the requirements of the ROD. The PMP and BMAP have many overlapping data requirements, and much planning has been done to combine sampling needs to save time and money. The EFPC PMP will use historical and current data from the BMAP as well as additional data described here. Using the BMAP sampling locations for the monitoring plan will provide three additional advantages. First, a single set of sampling locations will eliminate any potential interference effects on sampling that each program could have on the other if they were operating at separate but nearby locations. Second, using the BMAP sampling locations will provide comparative historical data, against which current and future monitoring results can be assessed. Third, cost savings will occur because locating and establishing new sampling locations will be unnecessary.

This document describes the EFPC PMP. It presents the scope and objectives of the program, summarizes background information about the site and related investigations, and describes the monitoring tasks that are unique and those that are similar to BMAP. It also projects uses of the data obtained by both monitoring programs. 


\section{SCOPE AND OBJECTIVES}

The overall purpose of the EFPC PMP is to confirm that remedial actions comply with the EFPC ROD, which specifies that those actions will be protective of human health and the environment, i.e., plant and animal populations (DOE) 1995b. The scope and objective of the PMP are described in more detail in the following subsections. The PMP does not include confirmatory sampling during remediation or any other sampling or monitoring during remedial action construction. Rather, it deals with sampling before (baseline) and after (postremediation monitoring) construction has been completed.

\subsection{SCOPE-BOUNDARIES OF MONITORING PROGRAM}

The Lower EFPC operable unit (OU) begins at the outfall of Lake Reality at the Y-12 Plant and ends at EFPC's confluence with Poplar Creek. The OU encompasses the 100-year floodplain of Lower EFPC. Contaminants released by the Y-12 Plant, primarily during the late 1950 s and early 1960 s, have been deposited in the floodplain, especially during floods. Most contaminants in EFPC and its floodplain are associated with particulate material, such as suspended sediment. Humans and ecological receptors in the OU are exposed to contaminants in soil, surface water, and sediment. The OU also includes the sewer line beltway that extends from the east end of the city of Oak Ridge to the EFPC floodplain. The beltway includes topsoil taken from the EFPC floodplain and used as fill material for the sewer line during its construction and, therefore, was evaluated for potential risks to human health and the environment.

The EFPC PMP focuses on a small number of locations within Lower EFPC and its floodplain. These locations are described in Chap. 4. Because no unacceptable risks were found for exposure to sewer line beltway soil and no cleanup was specified in the ROD, no monitoring will be done in the beltway.

Mercury is the sole contaminant of concern (COC) for all media except groundwater. Methylmercury is the primary COC for EFPC, its floodplain, and associated terrestrial and aquatic biota. Therefore, only total mercury and methylmercury will be analyzed in sampled media. The media sampled will be soil, sediment, surface water, and biota associated with these media. Sampling of sediment, surface water, and fish will be integrated with the sampling conducted by the Y-12 BMAP.

Monitoring will begin before remediation to provide a baseline, and it will continue for a minimum of two to five years (depending on the properties being monitored) after remediation. Sampling required to meet the objectives of the EFPC PMP but conducted by the Y-12 BMAP would have to continue even if the BMAP were to be discontinued during this time. At the end of five years, the protectiveness of remedial actions at Lower EFPC will be reviewed in accordance with the Comprehensive Environmental Response, Compensation, and Liability Act (CERCLA) statutory requirements [Sect. 120(a)(2)]. 


\subsection{OBJECTIVES-MONITORING COMPLIANCE WITH ROD}

The purpose of the EFPC PMP is to confirm that the remedial plan carried out under the ROD for Lower EFPC is protective of human health and the environment. The remedial plan for Lower EFPC includes (1) excavating soil from two locations that exceed the remedial goal (RG) for soil (400 $\mathrm{mg} / \mathrm{kg}$ ) and (2) no action at other locations for soil, sediment, surface water, and ground water. The selected remedy was judged to be adequately protective of the environment without causing undue destruction of forests and other habitats (DOE 1995b).

The ROD states that the mercury concentrations in surface soil must remain below $400 \mathrm{mg} / \mathrm{kg}$. Attainment of the soil RG will be confirmed during the construction phase of remediation and will not be monitored by wide-spread soil sampling during the PMP. In addition, consumption of drinking water from the shallow water table in the floodplain must not occur. The use of drinking water wells in the floodplain will be monitored in order to prevent the use of drinking water from the shallow water table.

For the remedial plan to be protective of the environment, three conditions must be met. First, the excavation of soil with mercury exceeding the RG must effectively reduce exposure. Second, the restoration of habitat at remediation sites must allow terrestrial populations to successfully recolonize the sites, and there must not be unacceptable effects of runoff from remediation sites on aquatic organisms living in EFPC downstream of the sites. Third, the exposure to and adverse effects on ecological receptors from mercury in unremediated soil, sediment, and surface water cannot cause unacceptable risk.

Unacceptable risk to ecological receptors can potentially result from the levels of mercury occurring in unremediated EFPC soil, sediment, and surface water. There is uncertainty about the levels of mercury in soil and sediment that are protective under current conditions (DOE 1995b). The preferred remedial goal option (RGO) for ecological receptors exposed to mercury in soil, $200 \mathrm{mg} / \mathrm{kg}$ (DOE 1995a,b), was based on a conservative scenario for ingestion by mid-level predators of soil-associated biota that ingest soil. However, the ROD does not require remediation of locations on the EFPC with soil mercury concentrations below the RG of $400 \mathrm{mg} / \mathrm{kg}$, stating that potential harm to the environment by remediation does not justify cleanup to the lower RGO. The Lower EFPC PMP will provide data on exposures of terrestrial and aquatic biota to mercury and methylmercury in the environment that will allow the protectiveness of the remedial plan to be evaluated.

\subsection{DATA QUALITY OBJECTIVES}

Data quality objectives (DQOs) have been established for the PMP to ensure that the protectiveness of human health and the environment can be rigorously evaluated. Steps in the DQO process include: (1) statement of the problem, (2) identification of key decisions, (3) identification of key environmental variables, (4) identification of spatial/temporal boundaries and affected populations, (5) specification of the decision rule, (6) specification of tolerance for uncertainty, and (7) development of the sampling plan.

\subsubsection{Step 1-Statement of the Problem}

The remediation plan for the EFPC floodplain is described in the EFPC Proposed Plan (DOE 1995a) and the EFPC ROD (DOE 1995b). The actions described by the ROD fit into the overall Oak Ridge Reservation (ORR) cleanup strategy by addressing floodplain soil and sediment contaminated by

mercury that originated from the Y-12 Plant. The objective of the remedial action is to minimize risks 
to human health and the environment from mercury contaminants in the Lower EFPC floodplain, as required by CERCLA and the Federal Facility Agreement (FFA) (DOE 1992). The selected remedy, as specified by the ROD, is summarized below.

\subsubsection{Remediation of floodplain soils}

The remediation goal for mercury in LEFPC floodplain soils is $400 \mathrm{mg} / \mathrm{kg}$. Areas where mercury levels have been identified to be $>400 \mathrm{mg} / \mathrm{kg}$ will be excavated and the excavated soil will be disposed of in a permitted landfill at the Y-12 Plant. After excavation is complete, confirmatory sampling will ensure that mercury concentrations at excavated areas are $<400 \mathrm{mg} / \mathrm{kg}$, and excavated areas will be filled with clean soil and revegetated. Because all soils that provide unacceptable exposures to humans will be removed, no further monitoring for human health is required. Areas that exceed $400 \mathrm{mg} / \mathrm{kg}$ and where excavation is required arelocated at the National Oceanic and Atmospheric Administration (NOAA) and Bruner sites and are shown in Figs. 2.1 and 2.2.

\subsubsection{Remediation of wetlands}

No remediation of wetlands at the NOAA site is anticipated under the terms of the selected remedy. A small portion of wetland COE ID No. 8 [0.24 ha ( 0.6 acres)] will be excavated at the Bruner site (Fig. 2.2). The wetland will be restored at the same location. Methods for wetland restoration are not described in the ROD but are provided in the Remedial Design.

\subsubsection{No-action decision for sediments}

RGOs for exposure of sediment-associated biota, aquatic biota, aquatic predators, and terrestrial piscivores were presented by DOE (1995c). The most conservative exposure scenario was that all mercury in EFPC sediments is methylated and that sediment-associated biota, aquatic biota, and piscivorous predators are exposed solely to pore-water, surface water, or prey contaminated by methylmercury leaching from the sediment. The least conservative scenario assumed that the fraction of methylmercury in sediment was that measured in sediments of Lake Reality (DOE 1994a), whereas an intermediate scenario assumed that $1 \%$ of sediment mercury is methylated. RGOs in the latter scenario ranged from $108 \mathrm{mg} / \mathrm{kg}$ for toxicity to pore-water invertebrates to $1630 \mathrm{mg} / \mathrm{kg}$ for toxicity to aquatic biota. Mercury concentrations in instream sediments of EFPC (up to $96 \mathrm{mg} / \mathrm{kg}$ ) are currently below the lowest of these RGOs for mercury in sediment. In addition, sediment elutriate toxicity testing showed no toxicity from sediments containing up to $73 \mathrm{mg}$ mercury $/ \mathrm{kg}$ (SAIC 1994).

\subsubsection{Attainment of permit levels for surface water}

No remedial activities on surface water will be undertaken under the EFPC ROD. Remediation of surface water is deferred to the DOE Y-12 Environmental Restoration Program, and continuing mercury releases from the Y-12 Plant will be regulated under the NPDES permit for the Y-12 Plant. Monitoring of the effects of surface water contaminants on aquatic biota is ongoing under the Y-12 Plant BMAP as a part of the NPDES permit for the Y-12 Plant. The purpose of the BMAP is to provide data to be used to protect the ecological integrity of EFPC. Therefore, remediation of surface water is not within the scope of the EFPC ROD. 


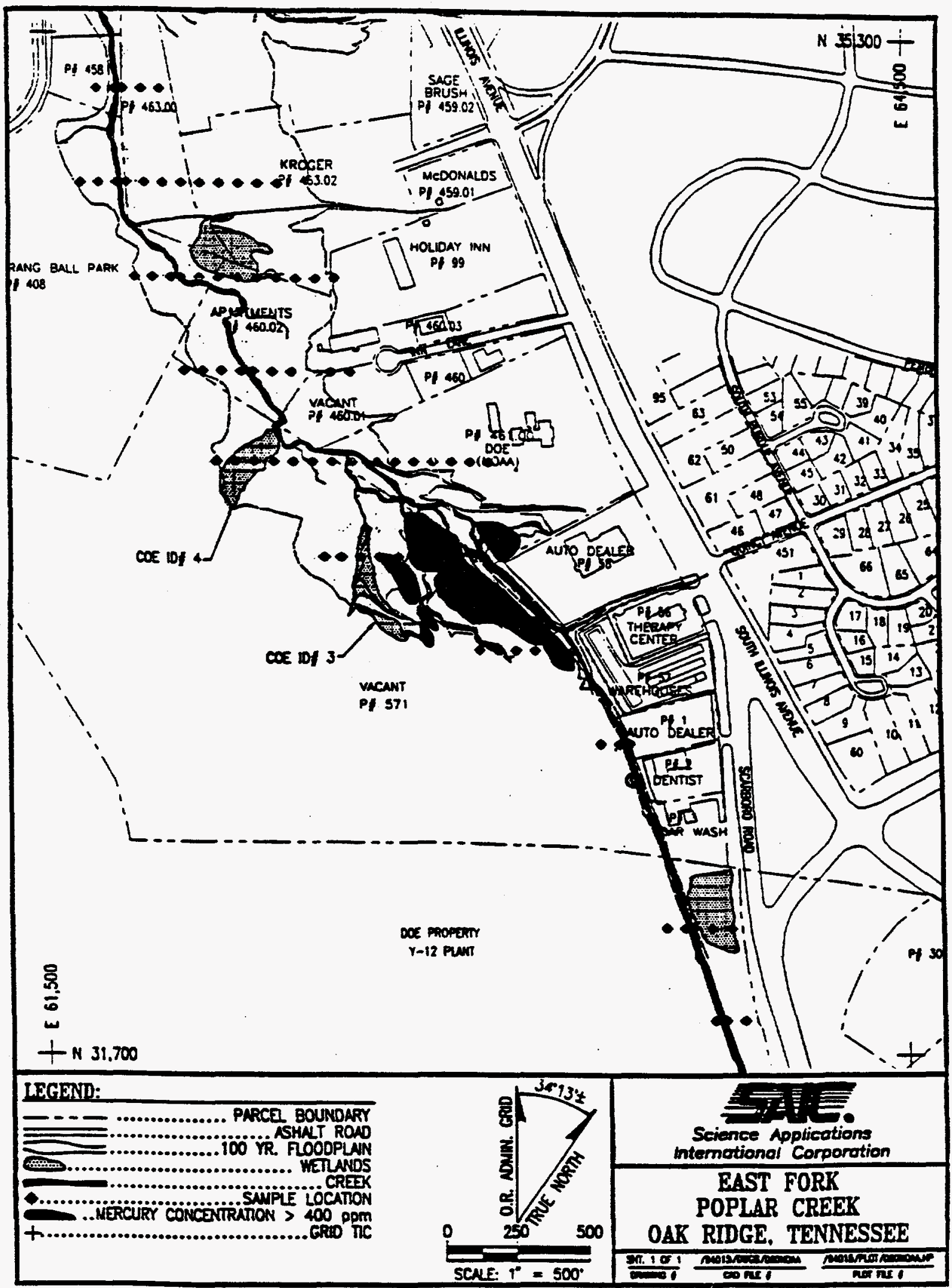

Fig. 2.1. Remediation areas at NOAA site. 


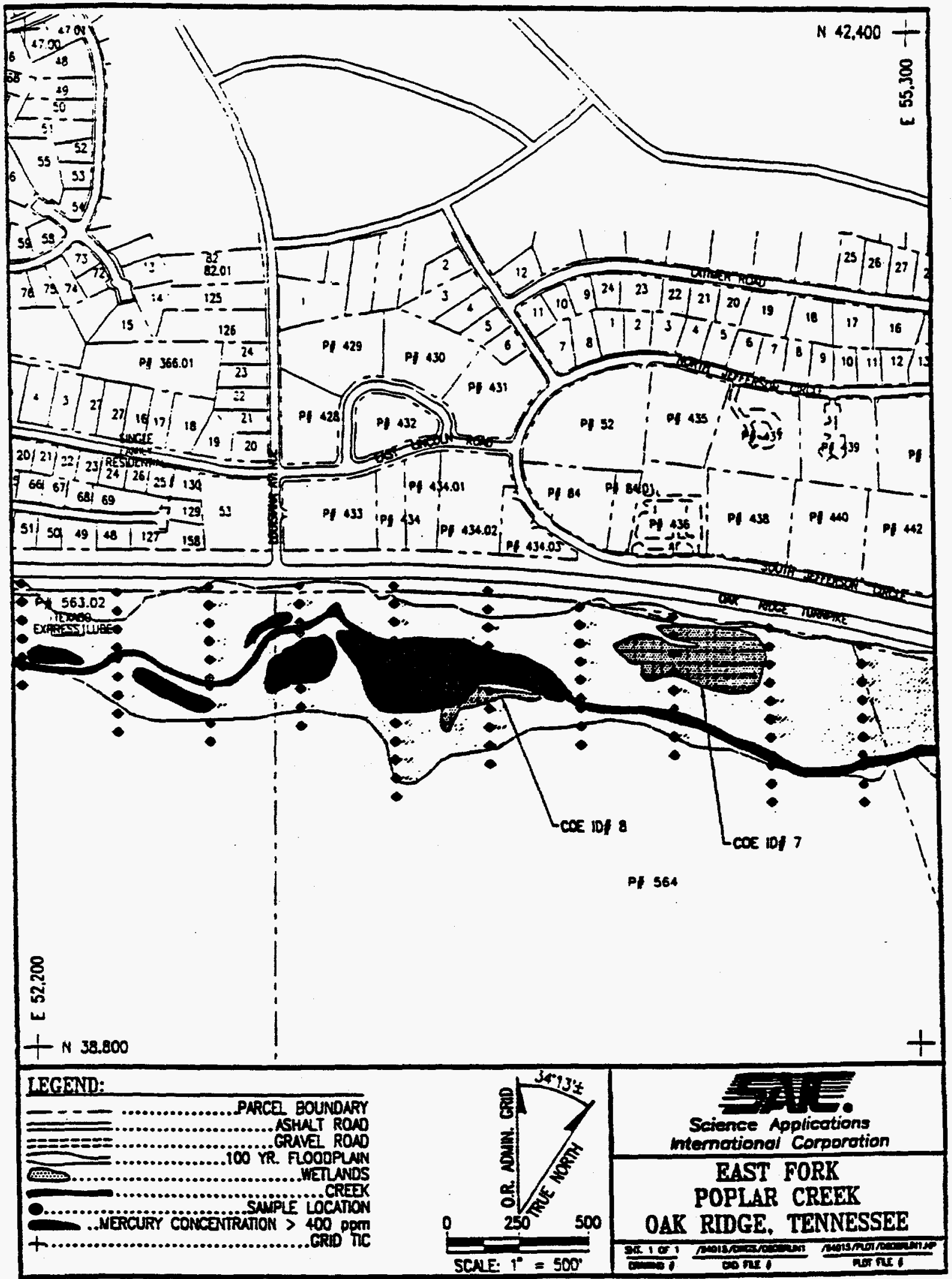

Fig. 2.2. Remediation areas at the Bruner site. 


\subsubsection{Protection of human health from contaminants in groundwater}

No remediation of groundwater will be undertaken under the EFPC ROD. Arsenic and manganese were identified in the RI as contaminants of concern in shallow groundwater, although background sampling was not done and it was not shown that the concentrations of arsenic and manganese were above background concentrations. No shallow groundwater wells in the EFPC floodplain are currently being used for drinking water. Protection of human health will be ensured by an annual visual surveillance to identify wells in the floodplain and, if any are found, mitigating their use as drinking water.

\subsubsection{Step 2-Identification of Key Decisions}

The EFPC ROD (DOE 1995b) specifies that a monitoring plan will be implemented to sample and analyze soil, sediment, surface water, and associated biota in Lower EFPC and its floodplain. The results are to be reviewed periodically to evaluate the protectiveness of the remediation plan. Postremediation monitoring will address the following issues:

- Several soil RGOs were proposed during the RI process that would be protective of ecological populations. There is uncertainty about how high the soil mercury concentration can be while remaining protective of ecological populations. Monitoring will provide data to evaluate whether populations are protected when mercury concentrations in soil remain above the ecological soil RGO of $200 \mathrm{mg} / \mathrm{kg}$, as well as when mercury concentrations are between $50 \mathrm{mg} / \mathrm{kg}$ and $200 \mathrm{mg} / \mathrm{kg}$.

- Residual soil mercury could potentially contaminate EFPC surface water and sediment. Monitoring will determine whether surface water and sediment mercury concentrations remain below established RGOs (DOE 1994b, DOE 1995c) and whether surface water and sediment remain nontoxic to aquatic and sediment-dwelling biota.

- Health risk from drinking groundwater from the shallow water table was demonstrated in the RI. Because there is currently no use of drinking water from that source, there will be no remediation of groundwater or most of the soil. However, potential exposure to groundwater will remain. Surveillance will determine whether there is a potential for ingestion exposure to groundwater by identifying use of groundwater wells.

- Wetlands will be excavated and reconstructed during remediation. Monitoring will determine whether wetland function has been restored in the reconstructed wetlands.

Key decisions for each medium are stated in detail in Chap. 4, where the sampling program for each medium is described.

\subsubsection{Step 3-Identification of Key Environmental Variables-Rationale for Monitoring to Confirm Compliance}

The EFPC ROD states that the proposed remedy for the EFPC floodplain is protective of human health and the environment. However, the ROD specifies that monitoring of soils, surface water, sediment, and associated biota and of groundwater use will be performed. The following subsections give the rationale for monitoring each of the relevant media. 


\subsubsection{Floodplain and wetland soils and biota}

The remedial goal for total mercury in floodplain and wetland soils is $400 \mathrm{mg} / \mathrm{kg}$. The ROD states that cleanup to the RGO (200 mg/kg) presented in the RI Addendum (DOE 1994b) would be unduly destructive to the environment and that the selected remedial goal of $400 \mathrm{mg} / \mathrm{kg}$ is protective of human health and the environment. The remedial goals for total mercury presented in the technical reevaluation of RGOs (DOE 1995d) are based on transfer of methylmercury from soil to mid-level predators. However, there is uncertainty about both the percentage of methylmercury in prey consumed by mid-level predators and the actual toxicity benchmark for populations for mid-level predators. Monitoring the concentrations of total mercury and methylmercury in soil-exposed organisms and their predators is appropriate to evaluate the protectiveness of the remedial goal.

\subsubsection{Surface water and biota}

The $\mathrm{RI}$ concluded that contaminants in surface water currently cause risks to aquatic receptors in EFPC (DOE 1994a). Mercury and polychlorinated biphenyls (PCBs) were identified as COCs in surface water. Additional studies (DOE 1994b) implied that the source of these contaminants is primarily in Upper EFPC, outside the Lower EFPC OU. The RI (DOE 1994a) concluded that attainment of the State of Tennessee Continuous Criterion value for mercury $(0.012 \mu \mathrm{g} / \mathrm{L})$ would be conservatively protective of aquatic biota, whereas an upper concentration level that would be protective has not been established. It is a requirement of the NPDES that releases into surface water are not harmful to aquatic biota. Therefore, attainment of NPDES permit levels in EFPC should be protective of aquatic biota; the Y-12 Plant BMAP provides data to evaluate protectiveness. A final NPDES permit has not taken effect at this time, so there are no final surface water quality criteria for EFPC.

An RG for surface water in Lower EFPC was not set in the ROD. The RI concluded that there are no current risks from surface water to human receptors, either by ingestion nor by direct contact (DOE 1994a). Although risks to aquatic receptors were attributed to contaminants in surface water (DOE 1994a), it was concluded that those contaminants most likely originate within the Y-12 Plant. Therefore, remediation of surface water is not within the scope of the Lower EFPC remedial process. Residual risks from contaminants in the Lower EFPC OU to aquatic organisms may currently be undetectable against the background of effects from the Y-12 Plant. However, historical data on surface water total mercury and methylmercury concentrations imply that methylmercury in filtered surface water originates in lower EFPC sediments rather than in the Y-12 Plant.

\subsubsection{Instream sediments}

The EFPC RI (DOE 1994a) concluded that instream sediments do not produce an unacceptable risk to humans from exposure during recreational activities or by other pathways. Although exposure pathways exist for sediment-associated and aquatic receptors in EFPC, the RGOs for sediment exposure via the food chain [z $197 \mathrm{mg} / \mathrm{kg}$ (DOE 1995c)] were higher than current sediment mercury concentrations of up to $96 \mathrm{mg} / \mathrm{kg}$ (DOE 1994a). The RI (DOE 1994a) and the RI Addendum (DOE 1994b) concluded that PCB exposures in aquatic biota are predominantly from surface water and that sediment PCBs most likely have not originated from DOE activities. However, there is uncertainty about the transfer of both mercury and $\mathrm{PCB}$ from sediment to sediment-associated and aquatic biota. There is also variability in the contribution of Y-12 Plant contaminant releases to sediment contamination in EFPC. Therefore, the effects of contaminants that potentially originate in sediment but whose effects are masked by contaminants in surface water will be monitored. 


\subsubsection{Groundwater ingestion}

The RI concluded that exposure by ingestion to contaminants in shallow groundwater presents a potential risk to human health. There is uncertainty about the potential risk of using drinking water wells in the floodplain, because the groundwater that was analyzed came from shallow wells that would not be used for drinking water and because no background comparison was done. Therefore, to prevent potential health risk from groundwater ingestion, the use of groundwater wells will be monitored by an annual surveillance of the floodplain. If a newly installed well is found at a residential site, DOE will determine whether it is being used for a drinking water source.

\subsubsection{Step 4-Identification of Spatial/Temporal Boundaries and Affected Populations}

Monitoring will be limited to Lower EFPC and its floodplain, along with appropriate reference areas, at sites specified in the sampling and analysis plan (Chap. 4) and the BMAP work plan. Monitoring results for surface water and sediment will be evaluated after two years, and if the results show no impacts of remediation, monitoring of these media will not be continued. Monitoring of soil and terrestrial biota will continue for five years, at which time monitoring may be discontinued if no impacts have been shown.

Surveillance for groundwater use will be limited to the Lower EFPC floodplain. The need for surveillance for groundwater use will be reevaluated as part of the five-year review. Monitoring of wetlands will be limited to the area of wetland that was excavated and reconstructed.

\subsubsection{Step 5-Specification of the Decision Rule}

Assessment endpoints will be evaluated after two years and five years of monitoring. Decision criteria for each endpoint are presented in Chap. 4. Mobilization of mercury species by remediation will be inferred if body burdens of earthworms and starlings or sediment mercury concentrations downstream of remediation sites increase after remediation. Adverse impacts of residual mercury in soil to terrestrial biota will be inferred if starling reproductive success is inversely correlated with soil mercury concentrations or if body burdens of methylmercury in starlings is above $2.5 \mathrm{mg} / \mathrm{kg}$. Adverse impacts of residual mercury in soil to benthic biota will be inferred if sediments are toxic to test organisms and toxicity is correlated with the remedial actions and with residual mercury concentrations. Adverse impacts of residual mercury in soil to aquatic biota and their predators will be evaluated by investigators and regulators using decision criteria and weight of evidence regarding ambient water toxicity, fish mercury body burdens, and fish community surveys. If monitoring shows no significant impacts of remediation and no apparent impacts of mercury at non-remediated sites, monitoring may be discontinued until the 5th year postremediation, after which the five-year review report will be prepared. Interruption of monitoring will occur only by agreement among DOE, U.S. EPA, and State of Tennessee.

Protection of human health will be ensured by an annual visual surveillance to identify wells in the floodplain. If a groundwater well is found in the Lower EFPC floodplain at a residential site and is found to be used for a drinking water source, DOE will mitigate such use in some appropriate way (DOE 1995b). 


\subsubsection{Step 6-Specification of Tolerance for Uncertainty}

Total mercury and methylmercury concentrations in sediment, earthworms, and starlings and reproductive success of starlings at each site and for each sampling event will be expressed in terms of mean and 95th percentile upper confidence limit (UCL) [lower confidence limit (LCL) where required] of the mean. Comparisons will be made using the 95th percentile UCL of the mean or the maximum, whichever is lower (95th percentile LCL or minimum, if appropriate).

Because baseline data are limited or nonexistent for some media (especially birds and earthworms), uncertainty in the preremediation baseline will be high. Therefore, a quantitative analysis of uncertainty in postremediation effects will not be reliable. Nor can a well bounded estimate of mercury body burdens or other parameters at one location be inferred to represent conditions at any other location. Instead, uncertainty will be evaluated qualitatively, taking into account the inherent variability of biological data and of the distribution of mercury in soils and sediments. The tolerance for uncertainty will be determined jointly by $\mathrm{DOE}$ and the regulators upon evaluation of the monitoring results.

\subsubsection{Step 7-Development of the Sampling Plan}

The sampling and analysis plan to be used to monitor postremediation effects in EFPC and its floodplain is detailed in Chap. 4. 


\section{SETTING, CONCEPTUAL MODELS, REMEDIAL GOAL OBJECTIVES, AND COORDINATION WITH Y-12 PLANT BMAP}

Chapter 3 discusses the CERCLA remediation process as it applies to the DOE ORR [including cooperation among DOE, EPA, the Tennessee Department of Environment and Conservation (TDEC) (formerly the Tennessee Department of Health and Environment), the U.S. Fish and Wildlife Service, and the U.S. Army Corps of Engineers]. The section also describes the study area and the EFPC conceptual models of mercury dynamics and reviews RGOs for EFPC and EFPC floodplain media. These discussions amplify on the problem statement step of the DQO process (Chap. 2.3.1).

The chapter then discusses the use of monitoring data to confirm that the remediation is protective of human health and the environment [related to key decisions (Chap. 2.3.2)] and describes how the EFPC PMP will be coordinated with the ongoing Y-12 Plant BMAP. These discussions contain elements related to key environmental variables (Chap. 2.3.3) and spatial/temporal boundaries of the study (Chap. 2.3.4).

\subsection{THE CERCLA REMEDIATION PROCESS.}

The RI and FS process constitutes the methods established by the Superfund program, which administers CERCLA, to characterize the nature and extent of contamination and risks posed by uncontrolled hazardous substances and to evaluate potential remedial options. Risk managers use the information, arguments, and comparisons presented in the RI and the FS to select a remedy that will best meet the necessary criteria for protectiveness: compliance with applicable or relevant and appropriate requirements; long-term and short-term effectiveness; treatment to reduce toxicity, mobility or volume; implementability; cost; and state and community acceptance (EPA 1988). The final remedy is then selected jointly by the lead agency (DOE in the case of the ORR), EPA, and TDEC and is documented in the ROD. The remedy is then implemented according to an approved remedial design.

The primary steps included in a CERCLA RI are (1) to collect data to characterize, or describe, site conditions; (2) to determine the nature and extent of contamination at the site; and (3) to assess current and future risks to human health and the environment if no remediation occurred. Information in the RI is used for the FS. The purpose of the FS is to provide decision makers with sufficient information to adequately compare the alternatives for site cleanup, to select a remedy for the site, and to demonstrate compliance with CERCLA remedy selection requirements. Risk assessments are also performed during the FS to determine if the proposed alternatives will be protective of human health and the environment.

\subsubsection{Federal Facility Agreement for the Oak Ridge Reservation}

On December 21, 1989, EPA placed DOE's ORR on the National Priorities List (NPL). On January 1, 1992, an FFA between the DOE Field Office in Oak Ridge (DOE-OR), EPA Region IV, and TDEC went into effect. This FFA established a schedule for meeting the requirements of the Resource Conservation and Recovery Act (RCRA), CERCLA, and the National Environmental Policy Act (NEPA). It established the procedural framework and schedule by which DOE-OR will develop, coordinate, implement, and monitor environmental restoration activities on the ORR in accordance with applicable federal and state environmental regulations. 


\subsubsection{East Fork Poplar Creek Remedial Process}

The Lower EFPC remedial process focuses on the 23-km (14.5-mile) stretch of EFPC flowing from Lake Reality at the Y-12 Plant, through the city of Oak Ridge, to Poplar Creek on the ORR and its 271 ha ( 670 acres) of floodplain. Both EFPC and its floodplain have been contaminated by hazardous, radioactive, and mixed waste releases from the Y-12 Plant since the early $1950 \mathrm{~s}$. The primary COC is mercury, with other heavy metals, radionuclides, and organics known to be present.

Because the EFPC site, designated as an ORR OU under CERCLA, is included on the NPL, its remediation must follow the specific procedures mandated by CERCLA, as amended by the Superfund Amendments and Reauthorization Act (SARA) in 1986. Because EFPC involves off-site release of contaminants from the Y-12 Plant, its remediation also must conform with the procedures of Sect. 3004(v) of RCRA, as amended by the Hazardous and Solid Waste Amendments of 1984. Because the actions taken to remediate EFPC may affect the environment, the potential environmental impact of those actions must be publicly addressed in accordance with the NEPA. The RI of EFPC, conducted from 1990 to 1994, integrated the requirements of these three primary federal regulations (CERCLA as amended by SARA, RCRA, and NEPA), as outlined in the FFA for the ORR, as well as other federal and Tennessee state regulations.

\subsection{DESCRIPTION OF EFPC OU}

The following subsections describe the geographic and ecological settings, the land uses and demographics, and the origin and transport of contaminants in the EFPC OU.

\subsubsection{Geographical Setting}

EFPC is a perennial stream located in Anderson and Roane Counties in Oak Ridge, Tennessee, about $40 \mathrm{~km}$ ( 25 miles) west of Knoxville (see Fig. 3.1). Its headwaters are contained in 54- to 72-in. (137- to $183-\mathrm{cm}$ ) underground collection pipes that extend from the west end to the central area of the Y-12 Plant, where the above-ground portion of the creek begins. Most of the water in the upper portion of the creek is process water pumped from the Clinch River. From the Y-12 Plant site, EFPC flows northward through a gap in Pine Ridge and flows by the entrance to Gamble Valley and enters the city of Oak Ridge. The stream flows northwestward along Illinois Avenue through commercial and light industrial areas in Oak Ridge, then trends generally westward, parallel to Oak Ridge Turnpike in East Fork Valley, through primarily residential, agricultural, and open areas, until it joins Poplar Creek. Poplar Creek empties into the Clinch River, which is impounded behind Watts Bar Dam.

From the point at which it exits Lake Reality to its confluence with Poplar Creek (termed Lower EFPC), the creek measures about $23 \mathrm{~km}$ (14.5 miles). Stream depths range from $<1 \mathrm{~m}$ to $3 \mathrm{~m}$ ( 3 to $9 \mathrm{ft}$ ). The 100-year floodplain varies in width from several meters in its upper reaches to about 500 $\mathrm{m}$ (1640 ft) and encompasses about 271 ha (670 acres). The course and streambed of EFPC have been modified as a result of Oak Ridge development; the creek has been channeled in some sections of town, and riprap has been added to protect the banks. Box culverts and bridge piers are present at roadway crossings, and numerous drainage ditches and lateral culverts traverse the floodplain and discharge to the creek. Major tributaries to EFPC include Tuskegee Branch, Robertsville Creek, Mill Branch, Gum Hollow Branch, Pinhook Branch, and Bear Creek. These contributions and the general urban and agricultural discharges to the watershed influence the quantity and quality of water in EFPC. 


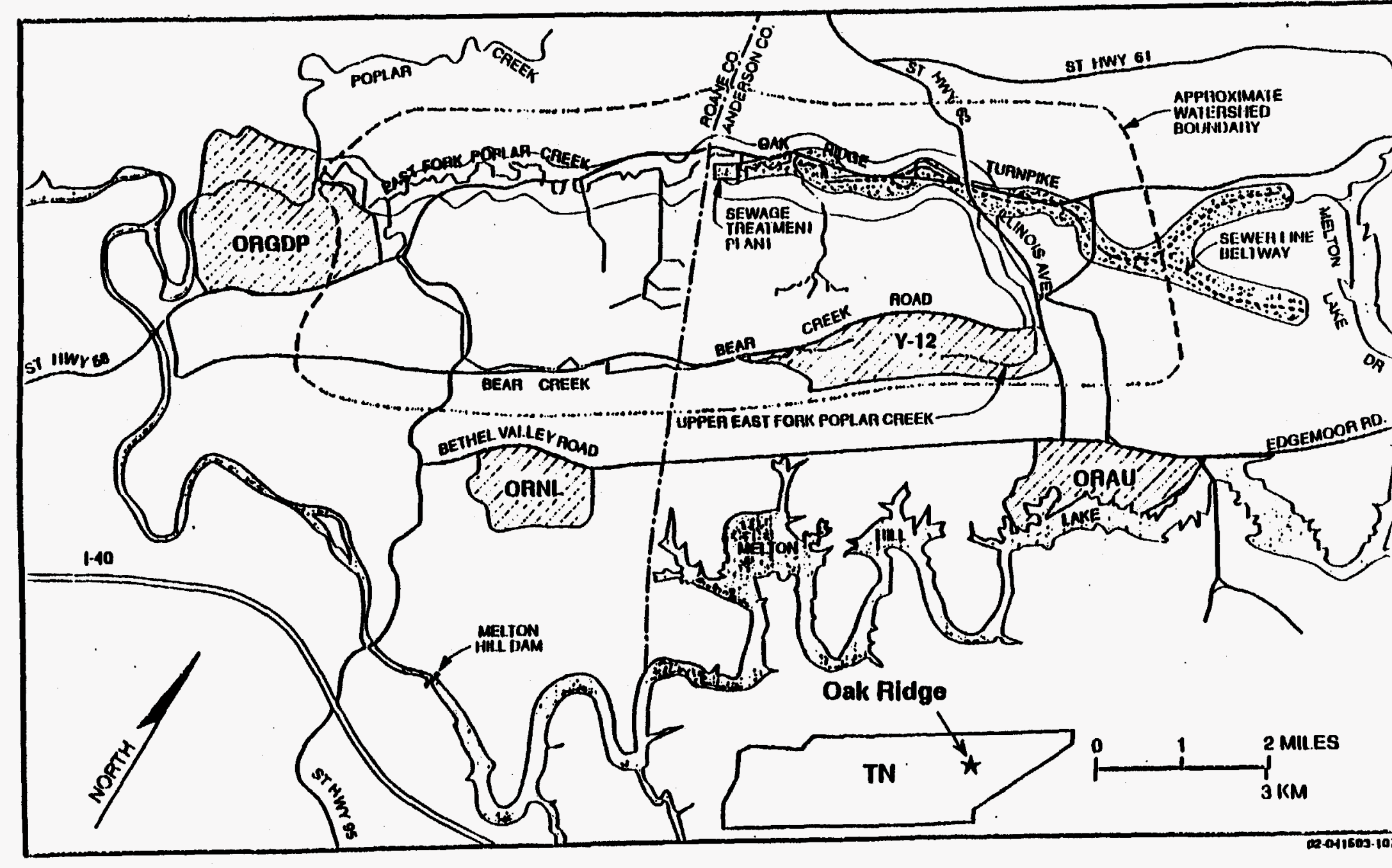


The EFPC watershed is located in the Valley and Ridge Physiographic Province of the Appalachian Mountains. This geologic structure produced a topography dominated by narrow elongated ridges and valleys, which trend to the northeast/southwest. The prominent valleys and ridges traversed by EFPC are, from north to south: East Fork Valley, East Fork Ridge, Gamble Valley, Pine Ridge, and Bear Creek Valley. Elevations within the study area range from $400 \mathrm{~m}$ (1300 $\mathrm{ft})$ at Pine Ridge to $225 \mathrm{~m}(740 \mathrm{ft})$ at the mouth of EFPC. Four different geologic units directly underlie EFPC along its course. These units include, in order of encounter downstream, the Conasauga Group, the Rome Formation, the Chickamauga Group, and the Knox Group. Soil types mapped in the EFPC floodplain belong to the Newark, Newark Variant, Hamblen, Sequatchie, Pope, and Roane Series.

\subsubsection{Land Use and Demographics}

EFPC traverses DOE property for $\sim 25 \%$ of its length. The remainder of the creek traverses properties that are owned by private citizens or the City of Oak Ridge. Although the land that falls within the 100-year flood boundaries of EFPC is mostly undeveloped, developed areas occur on adjacent land just outside the floodplain. As a result, land use in the vicinity of the site is diverse, including residential, commercial, agricultural, and open use. The residential category includes single- and multi-family housing units and schools. The commercial category includes offices, retail stores, restaurants, meeting places, and other establishments. Agricultural land use within the floodplain itself is limited to grazing of livestock and horses, with no current use for raising crops or family gardens. Open land use areas are those areas involving only incidental use, either through recreation or trespass.

In the RI, the EFPC and its floodplain were divided into nine segments based on geography, uniformity of land use, and similarity of contaminant levels. Present land use for the nine segments is estimated to be $7 \%$ residential, $2 \%$ commercial, $52 \%$ agricultural, and $31 \%$ open land. The remaining $8 \%$ of the EFPC site, including the creek itself and all roads and rights-of-way, is unclassified. The Oak Ridge 1988 Comprehensive Plan and current trends toward commercialization and residential development, however, suggest that floodplain areas now designated as open space are likely to convert to residential land use in the future. As a result, projected future use of the EFPC floodplain is estimated to be $29 \%$ residential, $12 \%$ commercial, $42 \%$ agricultural, $8 \%$ open, and $9 \%$ unclassified.

\subsubsection{Ecological Setting}

The EFPC OU is characterized by cleared areas, shrubs and herbaceous plants, and secondgrowth trees, which form thick stands up to the creek banks in many locations. Because of different land uses in the past, the woods are in various stages of ecological succession. The floodplain contains areas that have been filled to allow commercial development, and in places the creek has been channeled. Other portions of the floodplain contain agricultural tracts or grass and old field habitats. Terrestrial biota such as deer, raccoons, birds, and insects occur in all of these habitats. The creek contains several species of fish as well as benthic and other organisms typical of aquatic habitats characterized by limestone riprap to smooth and muddy stream bottoms in East Tennessee.

Three of the various types of natural terrestrial habitats that occur on the EFPC floodplain are bottomland hardwood forest, upland forest, and old field. Bottomland hardwood forest [135 ha, (334 acres)], upland forest [35 ha, (86 acres)], and old fields [24 ha, (60 acres)] are the most abundant of the 12 terrestrial habitat types identified on the EFPC floodplain. Wetlands occur in bottomland forest and old field habitats. Although wetlands are intermediate between aquatic and terrestrial habitats, they are considered here with the EFPC floodplain. One of the sites to be remediated, the 
NOAA site, is predominantly bottomland hardwood, whereas the other site to be remediated, the Bruner site, is predominantly old field.

Wetlands were inventoried by the U.S. Army Corps of Engineers (COE) along the entire length of the EFPC floodplain. Seventeen wetland areas were identified that exhibited all three regulatory wetlands criteria (COE 1992), comprising a total of $\sim 5$ ha (12 acres). The majority of those identified wetlands were $<0.4$ ha $(1$ acre $)$ in size. The 16 wetlands that lie within the 500 -year floodplain range in size from 0.04 ha $(0.09$ acre $)$ to 1.14 ha $(2.8$ acre $)$. One wetland lies within an area that is to be remediated and monitored (the Bruner site).

\subsection{EFPC CONCEPTUAL MODELS}

\subsubsection{Conceptual Model of Mercury Dynamics}

The various chemical forms of mercury react with physical and biological media and play a key role in determining the environmental impacts of mercury exposure in EFPC and its floodplain. The following discussion describes the conceptual model of mercury dynamics in the EFPC floodplain.

\subsubsection{Geochemistry of mercury in EFPC}

Mercury in the environment is subject to geochemical and biochemical reactions that produce a variety of chemical species. Elemental mercury may be oxidized to ionic species, usually termed inorganic mercury. Inorganic mercury may be methylated by biological processes in anaerobic sediments, and methylmercury may be reduced and demethylated to elemental mercury by biological and/or physical processes. Some contaminants bind to dissolved organic material and are unavailable for biological uptake. These contaminants are predominantly hydrophobic organic compounds, so species of mercury are not likely to bind to dissolved organic matter. Most mercury in EFPC soil is reported to be elemental or mercuric sulfide (DOE 1994b).

Both inorganic and methylmercury occur dissolved in surface water and pore-water. They also bind to particles in sediment or are suspended in the water column and may sorb to or desorb from particles under the appropriate conditions. Mercury present in water coming from the Y-12 Plant enters Lake Reality predominantly as inorganic mercury (both elemental and ionic), mostly in the particulate form. In Lake Reality, dissolved inorganic mercury is largely removed by sorption to sediment. At the sediment-water interface, methylmercury, again mostly particulate, is formed by bacterial action. In Lower EFPC, dissolved methylmercury may be sorbed to sediment, taken up by aquatic biota, first demethylated to dissolved inorganic mercury and then reduced to elemental mercury, or transported out of the EFPC system. Particulate methylmercury may be deposited in sediment, taken up by biota via ingestion, or transported out of the EFPC system. Dissolved elemental mercury may be sorbed to sediment, taken up by biota, reduced to elemental mercury by bacteria and volatilized, or transported out of the system. Both inorganic mercury and methylmercury may be leached from sediments to surface water. In pools or other areas where anaerobic conditions prevail, inorganic mercury may be methylated and released to surface water as methylmercury. Therefore, a steady state probably exists whereby methylmercury is being removed from surface water by some processes and generated by others, notably in sediment. Because particulate contaminants are not available for uptake by gill exchange or direct contact but may be available for uptake by ingestion, a description of the distribution of mercury species in the EFPC system is essential to predict exposures from sediment. 
The future distribution of mercury in EFPC sediments can be inferred from this knowledge of mercury transformations and known physical transport processes. In the short-term future (on the order of decades), mercury in EFPC sediments will continue to be moved around in a gradual downstream direction by resuspension and deposition during storm-flooding events. Additional mercury adsorbed to soil particles may enter the stream as soil sloughs from the creek banks or is transported from the floodplain to the creek. Modeling of the floodplain has indicated that $\sim 85 \%$ of mercury in the creek comes from the floodplain [Tennessee Valley Authority (TVA 1985)], but also that sloughing of soil will not likely increase the overall concentration of mercury in sediment, even if mercury concentrations in the floodplain remain at the current levels (DOE 1994c). Remediation of floodplain areas with mercury concentrations $>400 \mathrm{mg} / \mathrm{kg}$ will make the contribution of soil mercury to sediment even less. Without the contribution from the soil, mercury in the sediment could be $1-30 \mathrm{mg} / \mathrm{kg}$ (Norris 1993). Methylation of mercury in instream sediments will continue and the supply of mercury for this process is unlikely to be limiting over this time frame. Methylation is more likely limited by other factors (e.g., temperature, $\mathrm{pH}$, redox, electron donors) than the supply of mercury. In the long-term future (on the order of centuries), the concentration of mercury in EFPC sediment is likely to be reduced as mercury is transported out of the EFPC aquatic ecosystem by physical, chemical, and biological processes.

\subsubsection{Importance of methylmercury in EFPC food chains}

There is ample evidence that methylmercury, in particular, is taken up efficiently by some aquatic organisms (e.g., fish) from both water and ingested matter (Phillips and Buhler 1978). Because particulate contaminants are not available for uptake by gill exchange or direct contact but may be available for uptake by ingestion, a description of the distribution and transformations of mercury species in the EFPC system is essential to predict exposure from sediment.

Methylmercury is of more concern in food chains than inorganic mercury because it is more toxic to most organisms and it bioaccumulates in organisms to a greater extent than does inorganic mercury. For example, methylmercury comprises $<0.1 \%$ of total mercury in soil (DOE 1994a) and $<0.3 \%$ of total mercury in surface water (DOE 1994b), but the fraction of total mercury that was found to be methylated was $1.6 \%$ to $21 \%$ in central stonerollers and $11 \%$ to $40 \%$ in shiners (DOE 1994b). Methylmercury is less toxic to fish than inorganic mercury but more toxic to daphnids and aquatic plants (Suter and Mabrey 1994). Total mercury in EFPC floodplain soil is $~ 180$-fold less toxic to small mammals than is dietary methylmercury (Revis et al. 1989; Opresko, Sample, and Suter 1994).

The bioconcentration factor (BCF) from water or bioaccumulation factor (BAF) from soil is generally higher for methylmercury than for inorganic mercury. In studies done on biota in EFPC and its floodplain, BCFs observed were $\sim 5 \times 10^{5}$ to $\sim 1 \times 10^{6} \mathrm{~L} / \mathrm{kg}$ for methylmercury and $-3 \times 10^{3}$ to $\sim 2 \times 10^{4} \mathrm{~L} / \mathrm{kg}$ for total mercury (DOE 1995c). The BAF for total mercury observed in crayfish from EFPC wetlands was $\sim 9 \times 10^{-3}$; methylmercury did not show a consistent uptake pattern, but it ranged from $\sim 10 \%$ to $\sim 40 \%$ of total mercury in crayfish despite the low fraction $(\sim 0.03 \%)$ in soil where the crayfish were exposed (DOE 1994b). It is evident that selective accumulation of methylmercury through the food chain is to be expected. Monitoring data will help to confirm exposure from methylmercury to mid-level predators and top predators that to date have only been modeled.

\subsubsection{Conceptual Model of Soil and Associated Biota}

The conceptual model of the nature and distribution of contaminants in EFPC floodplain soil and the processes by which organisms are exposed to those contaminants is based on the results and discussions presented in the EFPC RI Report (DOE 1994a). The components of the conceptual model for the EFPC floodplain soil system are the soil and biota in different habitat types. 
Operating on the soil and biota in different habitats are the physical forces of nature: the fluid mechanics of EFPC and the weather (wind, temperature, precipitation). Contaminants introduced to the EFPC floodplain are transported primarily by water and wind. The fate of soil contaminants is influenced by the interactions of biota with contaminated soil and the interactions among different types of biota, predominantly interspecific feeding relationships. These elements of the conceptual model are discussed briefly below.

\subsubsection{Origin and nature of EFPC floodplain soils}

EFPC floodplain soils belong to the Newark, Newark Variant, Hamblen, Sequatchie, Pope, and Roane Series (DOE 1994a). Floodplain soils are typically characterized as deep, poorly to moderately well-drained, medium acid to mildly alkaline, with moderate to high available water capacity and total organic matter ranging from 0.3 to $>11 \%$ (Moneymaker 1981). They derive from the weathering of the four underlying geologic units: the Conasauga Group, the Rome Formation, the Chickamauga Group, and the Knox Group. Sediments carried by runoff from the watershed of $\sim 77.2 \mathrm{~km}^{2}(29.8$ miles ${ }^{2}$ ) are deposited by floodwaters overflowing the banks, resulting in the accumulation of deposited soil in low-lying areas near the creek. They may be hydric (SCS 1991), which could contribute to potential wetland formation. Soil thickness in the EFPC floodplain ranges from nearly zero at bedrock outcrops to as much as $6 \mathrm{~m}(20 \mathrm{ft})$ (Carmichael 1989). Geotechnical analyses of soil are presented in the EFPC RI Report (DOE 1994a).

\subsubsection{Nature and distribution of contaminants in soils}

Contaminants are heterogeneously distributed both vertically and horizontally in EFPC floodplain soil. Mercury levels are highest in soil between 16 and $32 \mathrm{~cm}$ (6 and $12 \mathrm{in}$.) deep, presumably reflecting historically greater releases of mercury from the Y-12 Plant (DOE 1994a). The horizontal patterns are more complex. Mercury concentrations are highest where low elevations have allowed the greatest deposition of contaminated sediment and lowest where little deposition has occurred.

Superimposed on a pattern of high variability on small spatial scales are three large-scale horizontal patterns of mercury contamination in EFPC floodplain soil. First, the (average) concentration in soil generally decreases with increasing distance from the plant. Second, the creek bank within a few meters of the water has elevated contaminant concentrations compared to points further from the creek. Third, scattered along the length of the floodplain are areas with concentrations of mercury and other contaminants that are elevated relative to their surroundings. As stated above, these "hot spots" are thought to be or have been areas where soil and sediment in floodwater are deposited, e.g., wetlands. For example, jurisdictional wetlands Nos. 7 and 8 are part of the contaminated Bruner site, which is also bottomland hardwood forest (Fig. 3.2). 


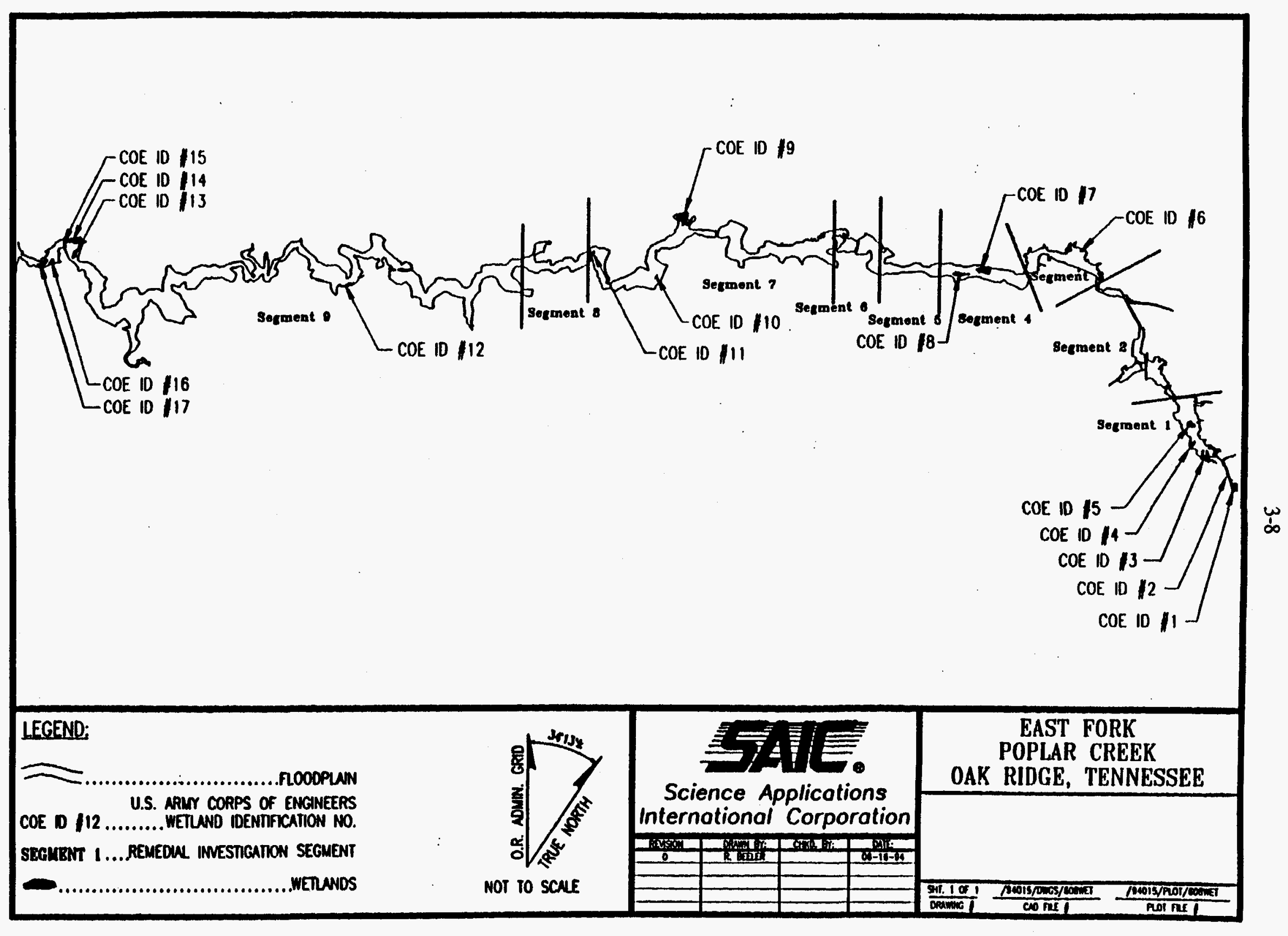

Figure 3.2. Jurisdictional wetlands in the EFPC noodplain 


\subsubsection{Wetlands in the EFPC floodplain}

Seventeen small regulatory wetlands (COE 1992) are distributed along the entire length of the EFPC floodplain (Fig. 3.2). The 16 wetlands that lie within the 500-year floodplain range in size from 0.04 ha ( 0.09 acre) to $1.14 \mathrm{ha}(2.8 \mathrm{acre})$, the average size being $0.32 \mathrm{ha}(0.78 \mathrm{acre})$. The total area of wetland habitat is equally distributed between bottomland hardwood forest [2.49 ha (6.16 acre)] and scrub-shrub [2.47 ha (6.1 acre)]. The wetland outside the 500-year floodplain is a small [0.18 ha (0.45 acre)] shallow pond.

In addition to being special wildlife habitat, some EFPC wetlands are thought to play an important role in the fate and transport of mercury. As floodwaters enter these wetlands, they slow down and deposit much of their load of sediment and contaminants, e.g., mercury, that are associated with particulates. Stagnant conditions in these wetlands during periods of normal streamflow may promote the production of methylmercury from inorganic mercury deposited there.

A special field investigation of EFPC was conducted to quantify the concentration of total mercury and methylmercury in wetland soil, foliage, amphibians, crayfish, small mammals, and trees (DOE 1994b). This investigation found that mean total mercury and methylmercury concentrations in soil and biota were higher in all EFPC wetlands sampled than at the reference sites [in Oak Ridge, Tennessee (soil) and near Oliver Springs, Tennessee (vegetation and animals)]; mean total mercury concentrations in trees did not differ between EFPC wetlands and non-wetland areas (DOE 1994b).

\subsubsection{Soil/biota interactions}

Most terrestrial organisms come into contact with soil at some point during their lives. Vegetation and animals, such as burrowing mammals, live in direct contact with soil. Some animals, like earthworms, ingest soil as a primary food source, others ingest soil incidentally in their burrowing or feeding activities, e.g., worm-eating shrews and birds.

Bacteria in the microscopic films surrounding soil particles are indirectly responsible for most of the transformation of inorganic mercury to methylmercury. For example, mercury methylation rates are thought to be lower in well-drained soil than in sediments or waterlogged soils where suitable redox conditions are more likely to occur.

\subsubsection{Soil-based food webs}

Mercury in soil enters the food web through plants, soil invertebrates, and other animals living in or on the contaminated soil. It is then passed to herbivores and predators. The greatest ecological risks in the EFPC floodplain from mercury in soil are based upon the exposure of mid-level predators (e.g., shrews and wrens) to mercury in the tissue and guts of their prey, i.e., earthworms and other soil-dwelling invertebrates. These trophic interactions are embedded in the larger food web of EFPC floodplain (Fig. 3.3). Predators of shrews and songbirds (e.g., raptors, foxes) are expected to have much lower exposure to mercury than songbirds and shrews because these top predators forage over larger areas that contain uncontaminated prey. Although the exposure of soil-dwelling invertebrates to mercury may be comparable to or greater than that of songhirds and small mammals, there is little information on the toxicity of mercury to soil invertebrates on which to base a risk assessment. Thus, the focus is on exposure of mid-level predators.

Important parameters governing the transfer of mercury from soil through earthworms to midlevel predators include the composition of the predators' diets and the BAFs for the different forms of mercury in their prey. The exposure of mid-level predators to methylmercury in their diet also depends on the fractions of methylmercury in soil and in animal tissue. Where no site-specific data for these parameters existed for EFPC, literature values were used to develop the exposure model. 


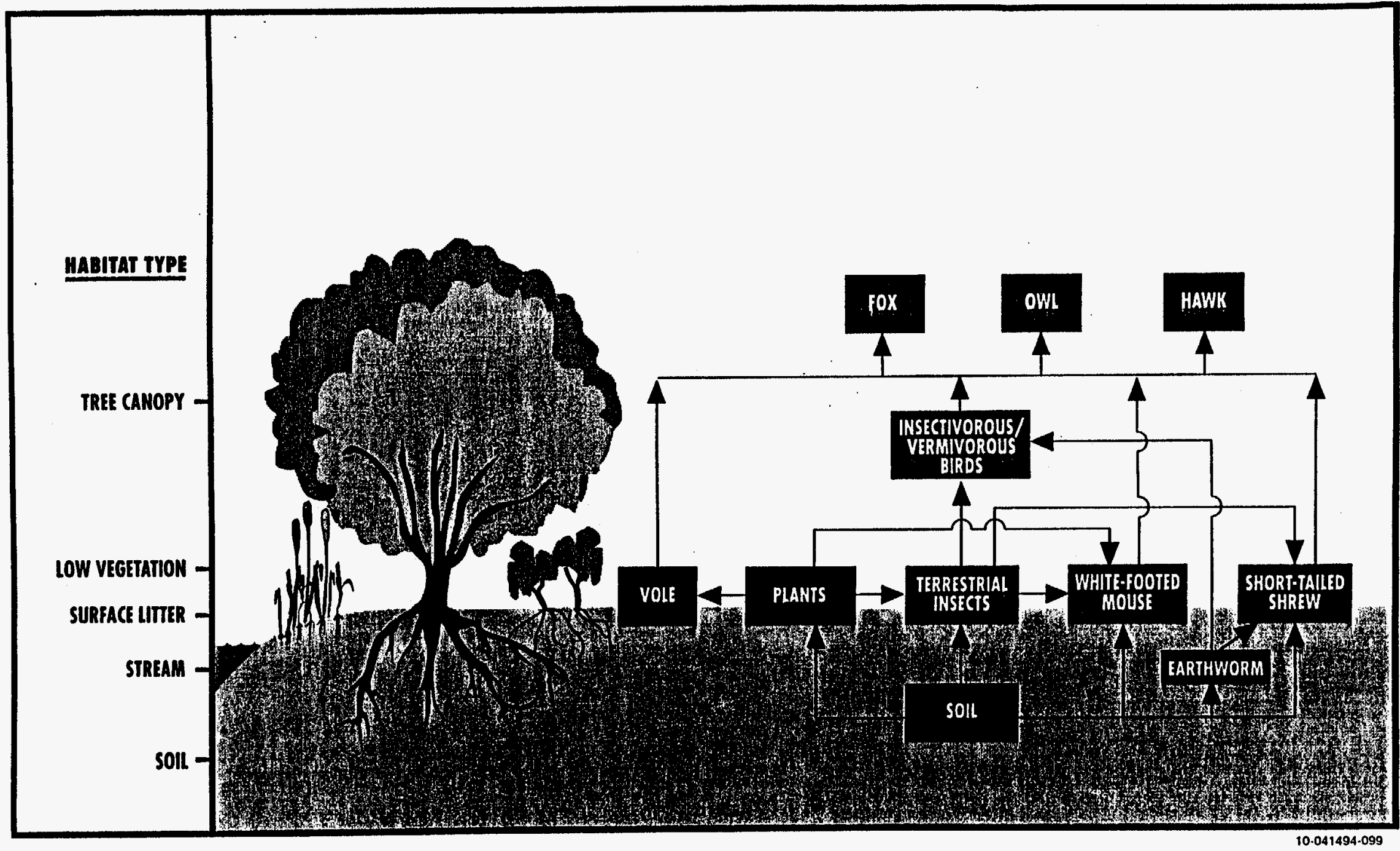

$\stackrel{\frac{1}{0}}{0}$

Fig. 3.3. Soil-based food web for the EFPC floodplain. 


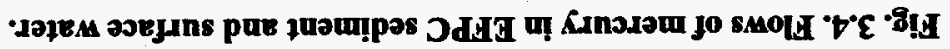

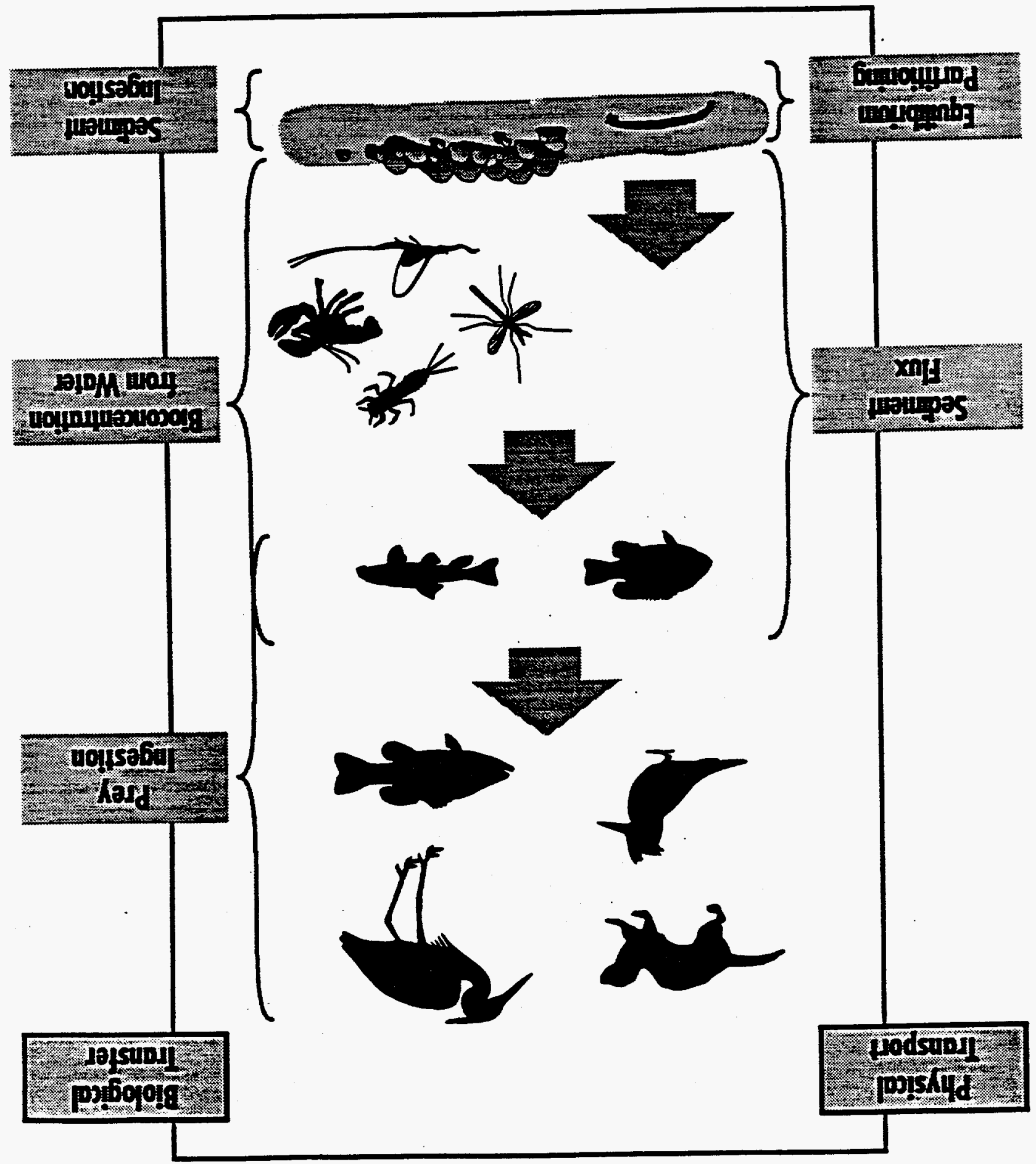

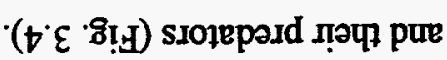

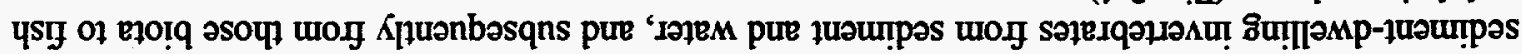

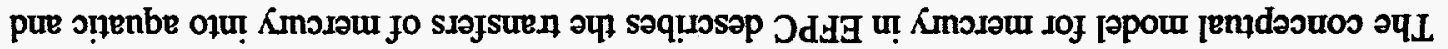

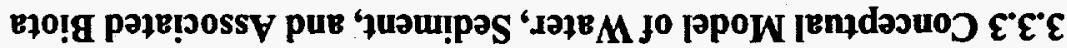


This model further includes the transfer of mercury from sediment to sediment-ingesting organisms; the bioconcentration of mercury in water by other prey of fish, as well as fish themselves; and the transfers of mercury in the bodies of prey organisms to forage fish, from forage fish to piscivorous fish, and from fish to fish predators. This model was used to estimate the body burdens of methylmercury in fish, which were then compared to dietary mercury concentrations that are protective of aquatic and terrestrial predators (Opresko, Sample, and Suter 1994).

\subsubsection{Origin and nature of surface water}

EFPC originates from springs and surface water drainage at the Y-12 Plant, on the northwest slope of Chestnut Ridge. The headwaters are contained in underground collection pipes that extend to near the central area of the Y-12 Plant, where the above-ground portion of the creek begins. The creek flows northeast across the plant site and enters Lake Reality, a lined 1-ha (2.5-acre) surface impoundment. The creek receives discharges of water from various processes at the Y-12 Plant, including cooling water and cooling tower blowdown, process waters, coal yard runoff, and storm drainage. The Clinch River is the source of the process waters. Average daily runoff of $\sim 0.06 \mathrm{~m}^{3} / \mathrm{s}$ [2.1 cubic feet per second (cfs)] would have been expected from the drainage area upstream of former New Hope Pond before the construction of the Y-12 Plant (TVA 1985). At the current average flow rate of $0.24 \mathrm{~m}^{3} / \mathrm{s}(8.6 \mathrm{cfs})$, EFPC flow is augmented by $0.18 \mathrm{~m}^{3} / \mathrm{s}(6.5 \mathrm{cfs})$ (DOE 1994a). Thus, a majority of the flow of EFPC as it leaves the Y-12 Plant is process water that was originally pumped from Melton Hill Lake. The average flow for Lower EFPC over a 25-year period of record is $1.5 \mathrm{~m}^{3} / \mathrm{s}$ (51.4 cfs), with flows from the Y-12 Plant and Oak Ridge West End Sewage Treatment Plant contributing $\sim 40 \%$ of that flow.

\subsubsection{Origin and nature of sediments}

Sediments in EFPC originate from soil and organic matter from the floodplain deposited into the creek during bank sloughing and other erosion processes and from sediment and other particulates that discharge from Lake Reality (TVA 1985) and EFPC tributaries. Sediment thickness in EFPC ranges from 0.15 to $1.7 \mathrm{~m}(0.05$ to $5.5 \mathrm{ft})$ and sediment distribution is intermittent. The approximate total volume of the sediment within EFPC is $55,400 \mathrm{~m}^{3}\left(72,500 \mathrm{yd}^{3}\right)$.

\subsubsection{Nature and distribution of contaminants in sediments}

Contaminant concentrations have been measured in EFPC sediments during three previous studies (Van Winkle et al. 1984; TVA 1985; DOE 1994a). The results show that creek sediments contain the same contaminants as floodplain soils but at lower concentrations. The pattern of contamination is not as predictable as in soil, however, presumably because of the transient nature of sediments within the creek. Reported concentrations of cadmium, ${ }^{137} \mathrm{Cs}$, copper, mercury, nickel, and uranium are significantly higher in the creek sediments than in the tributaries, although they are not high enough to cause unacceptable risk. The logical inference is that these analytes (and probably others) have a Y-12 Plant source (DOE 1994a).

Sediments were collected from EFPC during two phases of the RI sampling (DOE 1994a). Instream locations were selected to provide information on inputs to and outputs from EFPC, three known contamination hot spots within the floodplain soils, and points downstream from the Oak Ridge Sewage Treatment Plant and upstream from the Bear Creek tributary, which drains the west end of the Y-12 Plant. In Phase Ib, 25 composite sediment samples, each representing $600 \mathrm{~m}$ (1970 ft) of the creek, were obtained by establishing transects for soil sampling every $100 \mathrm{~m}$ (328 $\mathrm{ft}$ ), for a total of 159 transects, and sampling from the creek along every other transect. 
Mercury concentrations in sediment were generally below $20 \mathrm{mg} / \mathrm{kg}$ and ranged from 1 to $96 \mathrm{mg} / \mathrm{kg}$. The highest concentrations occurred at locations $\sim 9.6 \mathrm{~km}(6 \mathrm{mi})$ and $\sim 16 \mathrm{~km}(10 \mathrm{mi})$ downstream from the Y-12 Plant.

\subsubsection{Surface water/biota interactions}

Mercury in aquatic environments can enter biota by three biological transfer pathways. The three transfers are (1) uptake from sediment, (2) uptake from water, and (3) uptake from ingested living matter. Different types of aquatic biota obtain mercury by different combinations of one or more of the three biological transfer pathways. For example, floating plants would be exposed only to mercury dissolved in surface water. Most fish are directly exposed to mercury in both the food they ingest (prey) and the water they live in. The predominant form of mercury to which fish and their prey organisms are exposed by these pathways also varies. The mercury in predatory fish is primarily methylmercury, and birds and mammals that feed on them are especially sensitive to methylmercury (Eisler 1987). Accordingly, the body burden of fish that is protective of their predators is specified in terms of methylmercury. The mercury in sediment and water, on the other hand, is primarily inorganic mercury. The different forms of mercury in different media and their relative availability to fish and their prey have important consequences for the methylmercury body burden of fish-eating predators. For example, stonerollers in EFPC take up predominantly nonmethylated mercury from their diet of algae and sediment (DOE 1994b), whereas redbreast sunfish contain mostly methylmercury (Loar et al. 1992). Because methylmercury is more toxic to and bioaccumulates more in predators than nonmethylated mercury, a diet of redbreast sunfish would be more hazardous to predators than a diet of stonerollers.

\subsubsection{Sediment/biota interactions}

Mercury in EFPC sediment is transferred to the bodies of some aquatic animals primarily through direct ingestion of detritus and sediment and, to a lesser extent, contact with mercury dissolved in sediment pore-water. Fish, in particular, can acquire mercury from sediment either directly by sediment ingestion and direct contact with sediment pore-water, or indirectly by ingestion of other aquatic biota exposed to sediment. The ratio of the observed body burden of a given mercury species in an aquatic organism that is in contact with sediment and the measured concentration of that species of mercury in the sediment is called the bio-sediment factor (BSF). That is,

$$
B S F=\frac{\text { Body burden in receptor }(m g / k g)}{\text { Concentration in sediment }(m g / k g)}
$$

Mercury in sediment may also be released into the overlying water as a result of desorption or diffusion, thereby becoming available to fish and other biota dwelling in surface water. However, the estimated flux of mercury from EFPC sediments to the overlying water is small (DOE 1994c).

Sediment ingestion and contact with sediment pore-water are assumed to be the most important transfer pathways for those organisms that dwell in and ingest sediment. The body burden of mercury in these organisms (e.g., burrowing mayflies and chironomids) is primarily the result of these pathways because they ingest little other than sediment and spend their entire aquatic lives in the sediment (Borror and DeLong 1964; Barnes 1974). Experiments also suggest that the burrowing mayfly, Hexagenia rigida, is exposed to mercury in sediment more by ingestion than by direct contact with sediment pore-water (Odin et al. 1994) which may be rapidly exchanged with overlying surface water. 


\subsubsection{Water- and sediment-based food webs}

The transfer of mercury in sediment-based and aquatic-based food webs is shown schematically in Fig. 3.5. Mercury (both inorganic and methyl) from sediment is ingested by sediment-ingesting invertebrates, which also take up mercury by direct contact with sediment and pore-water. Invertebrates living in the surface water take up mercury by direct contact with water, and to a much lesser extent, sediment. Sediment-dwelling and surface water-dwelling invertebrates are eaten by forage fish, which also take up mercury by direct contact with water. Predatory fish are exposed by consumption of contaminated aquatic prey and by direct contact with water, and terrestrial piscivores are exposed by ingestion of contaminated aquatic prey. Because of bioaccumulation of methylmercury through the food web, piscivorous predators are the receptor group most likely to be at risk from exposure to mercury in sediment and surface water.

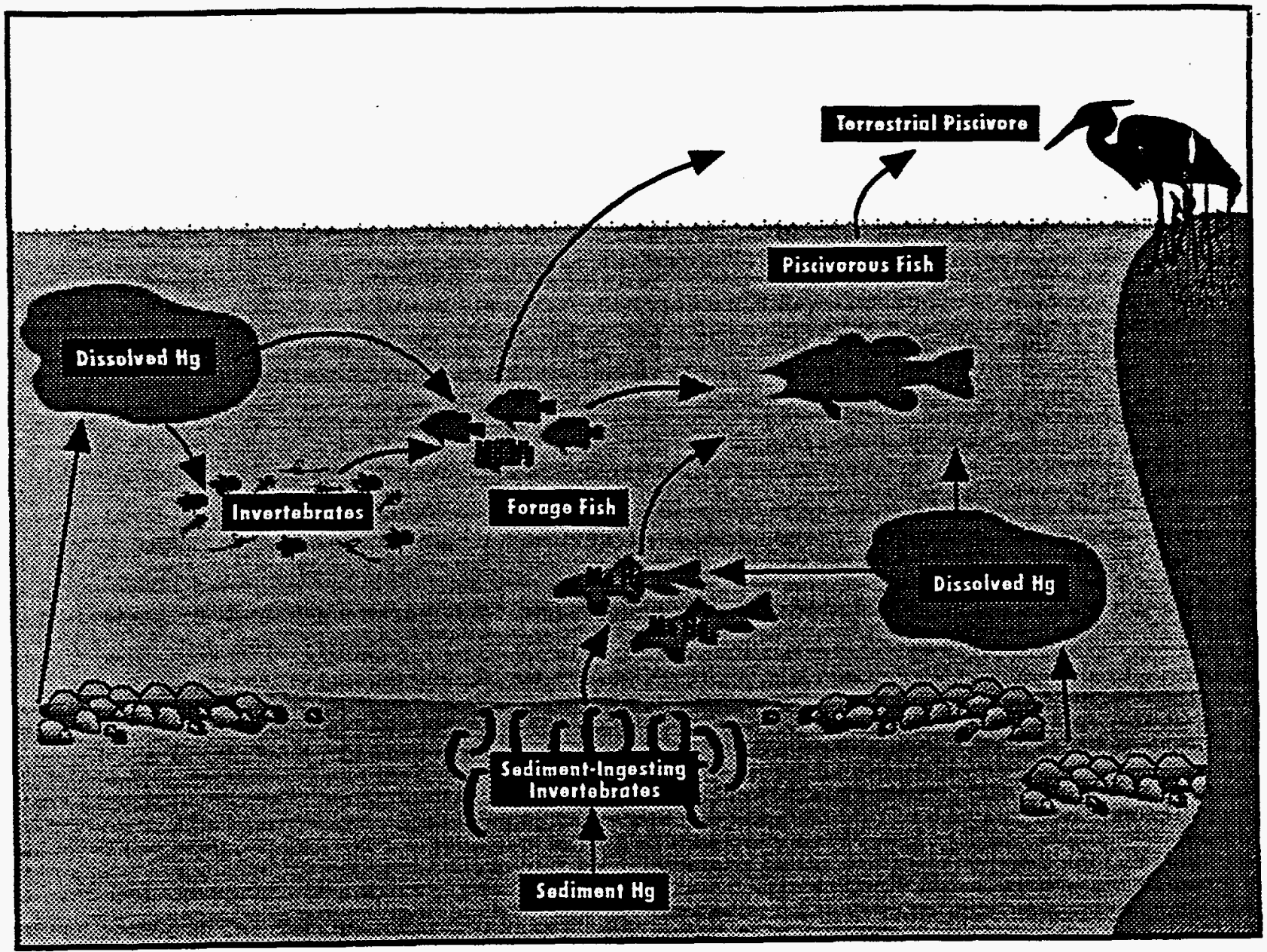

Fig. 3.5. Aquatic food web for the EFPC noodplain. 


\subsubsection{Conceptual Model of Human Exposure}

Human exposures to EFPC floodplain contaminants depend on which of the several current land uses applies at the exposure site. Exposures were evaluated in the RI for residential, agricultural, commercial, and open land uses. Potential routes evaluated for human exposure to contaminants in EFPC media included incidental ingestion of and direct contact with soil, ingestion of and dermal contact with surface water, dermal contact with sediment, ingestion and inhalation of groundwater, ingestion of food products (produce, beef, dairy, and fish), and inhalation of particulates. Under the residential scenario, exposures above a hazard index of 1 were found for soil ingestion by children and for ingestion of groundwater. Because the potential exists for residential land use in all of the land use segments of EFPC, the conceptual model for exposure to residual soils assumes that residential exposures may occur. The most sensitive receptor under the residential scenario is a child who incidentally ingests soil. Therefore, the remediation goal for soil was established to be protective of children ingesting soil under the residential land use scenario throughout the floodplain.

Potential future risks from ingesting groundwater from the shallow aquifer were identified in the RI, although no current use of shallow groundwater was identified. Remediation of shallow groundwater was not required by the ROD. However, monitoring use of shallow groundwater for human consumption is required.

\subsection{DESCRIPTION OF SOIL AND SEDIMENT RGOs}

RGOs are statements of contaminant concentration in a given medium that are protective of human health or ecological receptors under certain stated conditions. Soil and sediment RGOs were based on data about contaminant distributions, chemical forms, bioavailability, and exposure pathways in EFPC and its floodplain. Descriptions of the derivation of RGOs in soil and sediment are presented in the following subsection and then followed by discussions of key uncertainties; RGOs for surface water were not developed at this time.

\subsubsection{Remedial Goal Options}

RGOs were developed for soil and sediment in EFPC and its floodplain. The RGOs initially presented in the RI Report (DOE 1994a) were reevaluated in a number of supplemental documents (DOE 1994b, DOE 1995c, DOE 1995d). The RGOs and the methods of deriving them are presented in the following subsections.

\subsubsection{Soil RGOs}

The RGO for human exposure to mercury in EFPC soil is based on incidental soil ingestion by children. It assumes that the biological availability of mercury in EFPC soil is $10 \%$. Otherwise, exposure parameters are those described in the RI. The resulting RGO was $400 \mathrm{mg}$ mercury $/ \mathrm{kg}$ soil. This RGO was accepted as the remediation goal in the EFPC ROD.

Ecological RGOs for mercury in EFPC soil are based on assessment endpoints that protect terrestrial primary producers, mid-level predators, and top predators that feed in the EFPC floodplain. The RGO of $500 \mathrm{mg} / \mathrm{kg}$ protects the integrity of animal populations exposed to dietary methylmercury. The RGO of $200 \mathrm{mg} / \mathrm{kg}$ in the RI Addendum (DOE 1994b) achieves protection of mid-level predator individuals and populations. The measurement endpoint for both RGOs is the mercury concentration in the soil and in biota. RGOs were derived on the basis of dietary exposures of bird and small mammal populations, which are estimated by modeling the transfer of mercury through the food web. 
The transfer of mercury in soil through the food web to mid-level predators begins with the uptake of mercury from soil by their prey. Songbirds such as wrens are assumed to eat soil-dwelling invertebrates (insects and earthworms) and vegetation in various proportions; shrews eat insects, earthworms, and mice. The body burdens of mercury in these prey items are assumed to be proportional to the soil concentration. The proportionality factors are published or observed BAFs for mercury. These range from 0.0003 for mice, which eat only a small amount of soil, to 0.06 for earthworms (DOE 1994b).

The RGO equation for methylmercury in soil $\left(\mathrm{C}_{\text {soil }}\right)$, based on the benchmark concentration of contaminant in the diet of mid-level predators $(C D)$, is:

$$
C_{\text {soil }}=\frac{(E Q \times C D)}{\left(F I \times A B S \times \sum_{1}^{i}\left(p_{i} \times B A F_{i} \times D_{m e, i}\right)\right)}
$$

where the risk quotient (EQ), the fraction of diet from the contaminated area (FI), and the fraction of ingested dose absorbed (ABS) are all assumed to be unity; the compositions of the predators' diets $\left(p_{i}\right)$ are as in Table 3.8 of the RI Addendum (DOE 1994b); the BAFs are as in Table 3.9 of the RI Addendum (DOE 1994b); and the fraction of methylmercury in prey tissue $\left(D_{m e, i}\right)$ is assumed to be 0.025 to 0.04 .

\subsubsection{Sediment RGOs}

RGOs for mercury in EFPC sediment are based on an assessment endpoint that protects aquatic biota and their terrestrial predators. Biota are exposed to mercury in sediment pore-water, surface water, or the food and sediment they ingest. Three exposure scenarios were used to develop RGOs (DOE 1995c). In the most conservative (Scenario 1), it was assumed that all mercury is methylated, all ingested mercury is absorbed, and that the diets of all receptors consist of highly contaminated prey from EFPC. In the intermediate exposure scenario (Scenario 2), parameters were intermediate between the most conservative and the lower exposure scenario. In the lower exposure scenario (Scenario 3) EFPC comprised only a fraction of the home ranges of predators, the fractions of methylmercury in prey were based on published data and field studies, and diets were mixed.

The lowest RGO for sediment (108 $\mathrm{mg} / \mathrm{kg}$ ) was based on the exposure of Daphnia spp. to mercury concentrations in sediment pore-water predicted by an equilibrium-partitioning model using data from EFPC mesocosm experiments (DOE 1994c).

One assumption of the equilibrium-partitioning approach is that the partitioning model yields an estimate of the uncomplexed interstitial water concentration of chemical phases of sediments that control availability. Existing data support this assumption (EPA 1992a). Furthermore, concentrations of contaminants in interstitial water have been shown to correlate closely with toxicity (EPA 1992a). The toxicity sensitivity range for benthic organisms exposed to pore-water contaminants appears to be similar to the contaminants in the water column (EPA 1992a). Thus, using site-specific data for $K_{d}$, total organic carbon, and percent methylmercury in sediment from the EFPC mesocosm study, along with EPA-reported methylmercury chronic toxicity values for daphnids $(0.04 \mu \mathrm{g} / \mathrm{L})$ (EPA $1985 \mathrm{~b}$ ), a reasonable estimate of a threshold sediment mercury benchmark would be derived.

RGOs based on the risk to piscivorous birds and mammals ranged from 142 to 361 in the intermediate and lower exposure scenarios; their exposure to mercury in sediment resulted from 
ingesting aquatic biota with methylmercury concentrations predicted by a food-web model. RGOs for aquatic biota exposed to mercury concentrations in surface water predicted to result from the flux of mercury from sediment are larger than other RGOs for all exposure scenarios. These three models are described in detail in Remedial Goal Options for Mercury in Sediment of East Fork Poplar Creek, Oak Ridge, Tennessee (DOE 1995c).

\subsubsection{Surface water and groundwater in the RGO process}

RGOs were developed for exposure of fish and piscivorous predators to mercury in surface water and for human ingestion of groundwater in the RI Report (DOE 1994a). However, no remediation is planned for surface water because the predominant surface water contaminant is mercury released from the Y-12 Plant, which is outside the boundaries of the study area. No remediation is planned for groundwater because there is no actual exposure pathway. Therefore, no final remedial goals were developed for these media.

\subsubsection{Key Uncertainties in Model Assumptions}

There is uncertainty associated with exposure parameters and toxicity data in each of the equations used to develop RGOs for EFPC. Therefore, RGOs were derived for conservative toxicity endpoints using three exposure scenarios. These scenarios span the range from the maximum possible exposure (Scenario 1) to exposures more likely to occur at EFPC (Scenario 3). Key parameters, as defined by their influence on RGOs for mercury in EFPC soil and sediment, are discussed below.

\subsubsection{Uncertainties in soil RGOs}

One of the most important parameters determining the RGOs for EFPC floodplain soil is the concentration of methylmercury in terrestrial biota. The RGOs for mercury in soil were based on the predicted total mercury concentrations in terrestrial biota ingested by mid-level predators and reported values for the percent methylmercury. Percent methylmercury values in Scenario 1 were based on the range of 1 to $4 \%$ methylmercury observed in sparrows at Almaden, Spain (Hildebrand et al. 1980).

Other important parameters for the RGO for mercury in EFPC soil are BAFs for animals exposed to mercury in soil and the composition of the diet of mid-level predators, e.g., wrens and shrews. Mercury body burdens were predicted from the measured concentration of mercury in soil and BAFs. The key BAFs for the soil RGO for mercury were those for earthworms (0.06) and insects (0.006). Insect BAFs were based on EFPC data (Talmage and Walton 1993); earthworm BAFs were based on published values for other locations (EPA 1985a). Diets of EFPC mid-level predators are likely to vary with the availability of prey and the nutritional needs of the predator. In Scenario 3 (lower exposure), it was assumed that earthworms constitute only $15 \%$ of the diet of wrens. The relatively high earthworm BAF (10 times the insect BAF), balances to some degree the potential for underestimating risk to mid-level predatory birds by assuming only $15 \%$ earthworms in their diet.

\subsubsection{Uncertainties in sediment RGOs}

There are uncertainties in each of the three models used to derive RGOs for merany in EFPC sediment. Common to all three models is the uncertainty of using observed ratios of dissolved to total mercury and methyl to total merary from mesocosms to represent EFPC. Sediment mercury concentrations, stream flow, and other envinonmental parameters in EFPC vary considerably in space and time, so there is uncertainty about whether mesocosm conditions represent the worst possible case for mercary exposure. Uncertainties about key parameters influencing RGOs derived from each model individually are summarized below. 
The RGO for mercury in EFPC sediment based on the exposure of aquatic biota to sediment pore-water depends critically on the sorptive characteristics of sediment. Mesocosm sediments cannot represent all sediments in EFPC, but likely represent sediments in depositional areas where the proportion of clay and silt would be high. Clays and silts would generally tend to have greater adsorptive capacity than sandy sediment, be more likely to achieve equilibrium with sediment porewater, and have redox conditions more suitable for methylation of mercury. These characteristics would make the RGO for exposure to pore-water conservative for the preponderance of sediments in EFPC.

The RGO for mercury in EFPC sediment, based on the exposure of aquatic biota to surface water contaminated with mercury fluxing from sediment, also depends on the physical-chemical properties of sediment. The flux of mercury from sediments like those in the mesocosm enclosures would likely be lower than the flux from coarser grained EFPC sediments. The fact that mesocosm sediments underestimate the flux of mercury from EFPC sediment to the overlying surface water does not result in an RGO that is too high because the toxicity endpoint for exposure to mercury in surface water is based on the toxicity of methylmercury, not inorganic mercury. As described above, methylmercury concentrations in fine grained mesocosm sediments likely overestimate the concentration of methylmercury in coarser grained EFPC sediments.

The RGO for mercury in EFPC sediment based on the exposure of predators to prey contaminated with mercury depends critically on predicted mercury concentrations in aquatic biota and the percent methylmercury in sediment. Thus, there is uncertainty in the measurement endpoints associated with this assessment endpoint. The methylmercury concentrations in biota are predicted from the concentrations of methylmercury in sediment and surface water (contaminated by sediment) using BSFs, BCFs, and BAFs. Thus, the percent methylmercury in sediment and these transfer factors ultimately influence the dietary exposure of predators. Transfer factors were derived from published observations, not EFPC data. The observed percent methylmercury in mesocosm-enclosure sediment was used in the food web model. The dietary exposure of predators depends on the composition of the diet relative to the different prey types with different exposures to mercury in sediment. Conservative assumptions about percent methylmercury in sediment and conservative toxicity endpoints based on the concentration of methylmercury in the diets of predatory fishes, birds, and mammals result in RGOs that are protective.

\subsection{COORDINATION WITH Y-12 PLANT BMAP}

The Y-12 Plant BMAP is a good source of information about exposure to and effects of contaminants in aquatic biota in Lower EFPC. Much of the information from the BMAP investigations is compatible with the objectives and intended uses of the EFPC PMP. Therefore, information from the BMAP investigations will be incorporated into the PMP as fully as possible. Further, the PMP and BMAP are intended to overlap a great deal. This serves to optimize the time, money, and talent required for monitoring.

\subsubsection{Scope of the Y-12 Plant BMAP}

The Y-12 Plant BMAP was implemented in compliance with the draft NPDES permit issued for the Y-12 Plant in May 1985 (Loar et al. 1992). The BMAP was intended to demonstrate that effluent limitations established in the permit were sufficient to allow recreation and the growth and propagation of fish and aquatic life in the creek - the classified uses of the creek designated by the State of Tennessee. The BMAP was also intended to provide an ecological characterization of EFPC. The BMAP has included four major tasks that assess different aspects of the health of the biotic 
communities in EFPC: ambient toxicity testing, bioaccumulation of pollutants, biological indicator studies, and community surveys of fish and benthic invertebrates. Ecological effects are evaluated at different levels of biological organization - from tissues in individuals to communities.

BMAP conducts effluent and ambient toxicity tests to assess the impacts of $\mathrm{Y}-12$ Plant operations on EFPC biota. Endpoints are survival and reproduction of Ceriodaphnia dubia after 7-d static-renewal exposures.

Bioaccumulation studies assess organism-level bioaccumulation of mercury, other metals, and PCBs in fish fillets [redbreast sunfish (Lepomus auritus) and largemouth bass (Micropterus salmoides)], as well as a variety of organic contaminants in the soft tissues of caged asiatic clams (Corbicula fluminea). The body burden data integrate contaminant uptake in the organisms from all exposure pathways.

Biological indicator studies focus on tissue-level biochemical responses of fish that indicate exposure to general, and in some cases, specific stressors. For example, DNA integrity and metal binding protein concentrations are used as indicators of contaminant exposure.

Ecological surveys focus on periphyton, benthic macroinvertebrate, and fish communities within the stream. The periphyton community forms the base of a food web in the stream, whereas the fish integrates cumulative effects over all food webs and transfer pathways.

\subsubsection{Compatibility of Sampling Locations}

Biological monitoring is being done at several sites in Lower EFPC, including five sites for contaminant bioaccumulation (EFPC km 23.4, 18.2, 13.8,6.3, and 2.1) and five sites for ambient toxicity monitoring (EFPC km 22.8, 21.9, 18.2, 13.8, and 10.9). Specifications used in the selection of sites (Loar et al. 1992, Hinzman et al. 1993) included:

- location of sampling sites utilized in other studies,

- known or suspected sources of downstream pollution,

- proximity to DOE ORR boundaries,

- concentration of mercury in adjacent floodplain,

- proper combination of habitat requirements, and

- accessibility.

Reference sites are located in streams outside the EFPC drainage basin, e.g., Brushy Creek, Beaver Creek, and Hinds Creek. A description of BMAP activities can be found in the following documents: Loar et al. (1989), Loar et al. (1992), Hinzman et al. (1993), Hinzman et al. (1995).

The EFPC PMP will utilize sampling locations adopted by the BMAP. More detailed discussions of sampling location selection for sediment, as well as surface water and aquatic biota, are presented in Chap. 4.2.3. The rationale for selection of the BMAP sampling sites is consistent with the objectives of the monitoring plan. Using BMAP sampling locations for the monitoring plan will provide three additional advantages. First, a single set of sampling locations will eliminate any potential interference effects on sampling that each program could have on the other if they were operating at separate but nearby locations. Second, using the BMAP sampling locations will provide comparative historical data, against which current and future monitoring results can be assessed. Third, cost savings will occur because locating and establishing new sampling locations will be unnecessary. 


\subsubsection{Compatibility of Sampling Schedules}

Sampling activities for sediment, sediment-associated biota, surface water, and aquatic biota for the EFPC PMP will be performed concurrently within the existing BMAP sampling schedule. Semiannual sampling in late fall and spring, which is when the BMAP ecological surveys are performed, would be consistent with the goals of the PMP. Collecting samples for the PMP concurrently with the BMAP sampling will eliminate any potential interference on sampling that each program could have on the other if they were operating at different schedules.

\subsubsection{Use of Y-12 Plant BMAP Data in the Remedial Monitoring Process}

Results from the BMAP will be used directly to support the remedial monitoring process. The toxicity tests provide evidence that will be used to assess impacts to ecological resources. Ambient water toxicity tests will verify presence or absence of adverse effects that are most likely due to contaminants in the media. These results will be used along with fish body burden data and physical media analytical data that are specified for collection in this EFPC monitoring plan, to assess contaminant exposure, and provide additional evidence that will be used to assess ecological effects. Comparison of these data to 10 years of preremediation data will help distinguish changes in mercury exposure from naturally occurring variation. BMAP data will be used whenever possible, but some fish body burden analyses are not a planned part of BMAP; these analyses and sediment analyses will be performed for the PMP in conjunction with the BMAP sampling. Studies done in 1995 of total mercury and methylmercury concentrations in unfiltered and filtered samples of surface water will serve as the preremediation baseline for mercury species in surface water.

There are no monitoring data for terrestrial biota comparable to those of the BMAP for aquatic biota. Results from the RI will be used where appropriate to supplement baseline data collected by the PMP. 


\section{MONITORING TASKS}

The monitoring program for EFPC soil, sediment and surface water and their associated biota is described below. The monitoring programs for soil and associated biota is described first. Portions of the monitoring program for sediment and surface water are presented together because their monitoring rationales and goals are identical.

\subsection{MONITORING SOIL AND ASSOCIATED BIOTA}

The monitoring program for EFPC for soil and associated biota is described below. The recommendations for monitoring of soil and associated organisms are summarized in Table 4.1. The described monitoring for soil and terrestrial biota is an extension of BMAP, which is currently limited to the aquatic environment.

\subsubsection{Monitoring Rationale}

Monitoring of soil and associated biota on the EFPC floodplain is necessary to evaluate the protectiveness of the remedial plan. According to the ROD (DOE 1995b), only those areas on the EFPC floodplain with total mercury concentrations in soil exceeding the RG for protection of human health and the environment, $400 \mathrm{mg}$ total mercury/ $\mathrm{kg}$ soil, will be remediated. The protectiveness of removing soil from the two areas where total mercury exceeds $400 \mathrm{mg} / \mathrm{kg}$ and of leaving unremediated many areas with total mercury concentrations in soil below $400 \mathrm{mg} / \mathrm{kg}$ must be evaluated.

Remediation of the two EFPC locations with $>400 \mathrm{mg} / \mathrm{kg}$ will decrease the risk to both human and ecological receptors exposed to soil mercury at these two sites. Contaminated soils will be excavated and replaced with clean soil. The sites will then be revegetated. Monitoring of these two sites will allow evaluation of the protectiveness of remediation and possible unexpected effects of soil removal and revegetation on ecological receptors.

Monitoring sites with soil mercury up to $400 \mathrm{mg} / \mathrm{kg}$ will allow evaluation of the protectiveness of leaving these soils unremediated. The chosen RGO for protection of ecological receptors from mercury in soil is $200 \mathrm{mg} / \mathrm{kg}$ total mercury (DOE 1994b), although $500 \mathrm{mg} / \mathrm{kg}$ total mercury in soil is predicted to protect populations of the most at-risk ecological receptors, mid-level predators exposed to mercury in soil from ingesting soil-dwelling invertebrates (DOE 1995b). There is sufficient uncertainty about the risk to mid-level predators exposed to soil with up to $400 \mathrm{mg} / \mathrm{kg}$ total mercury to warrant monitoring. Moreover, the nature of the mercury that continues to be input into the floodplain, the environmental conditions influencing mercury methylation rates, and other environmental factors could change upon remediation, thereby increasing the exposure of biota to mercury. If the exposure of biota to the different forms of mercury increases enough to cause adverse effects, the decision to remediate only locations with $>400 \mathrm{mg} / \mathrm{kg}$ mercury in soil can be reevaluated at the end of the 5-year monitoring program. Monitoring will permit this evaluation to be made. 
Table 4.1. Selection specifications and recommendations for monitoring of soil and soil-exposed organisms

\section{Selection criteria}

Analytes: Mercury is the ecological COC. Methylmercury is the form of mercury of most concem for ecological receptors.

Matrices: Should be relevant to the soil RGO, whose most sensitive point is entry of methylmercury into the food chain. Should be abundant, biota should have small feeding range that could be restricted to the contaminated floodplain.

Where to sample: Locations will be chosen to represent range of mercury exposure conditions in soil (concentrations in soil, uptake by soil biota, uptake by mid-level predators). Two locations will show the results of remediation on exposure of biota. Two locations will show the effects of not remediating an area with fairly high mercury concentrations.

When to sample: Should sample when exposed biota will reflect seasonal changes in exposure. Should sample during the warm season to see any potential seasonal increases in mercury methylation in soil or biota.

\section{Additional information:}

Reproductive success when sampled.

Soil toxicity information relative to forms of mercury in the soil will be necessary if earthworm densities are too low to permit adequate sampling.

\section{Recommendations}

Recommended analytes: Total and methylmercury should be analyzed in all matrices.

Recommended matrices: Soil, depurated earthworms, starling eggs and nestling bodies. Earthworm toxicity tests on soil if earthworm populations are too small for adequate sampling.

Recommended locations: NOAA and Bruner areas to show effects of remediation, Jackson farm to monitor nonremediated areas $>50 \mathrm{mg} / \mathrm{kg}$ but $<200 \mathrm{mg} / \mathrm{kg}$, and Grandcove fields to monitor nonremediated areas $>200 \mathrm{mg} / \mathrm{kg}$ but $<400 \mathrm{mg} / \mathrm{kg}$. One reference location at Freels Bend.

Recommended times: During spring to reflect exposure of earthworms to deep soils and exposure of starlings to contaminated invertebrate prey.

\section{Recommended observations:}

Determine frequency of occupied nest boxes at each site, numbers of eggs laid, proportion of offspring hatched and fledged, and occurrence of gross birth defects in nestlings.

Perform ambient soil toxicity tests if earthworm populations are too low to permit adequate sampling. 


\subsubsection{Monitoring goals}

The goal of the PMP for EFPC floodplain soil and associated biota is to provide the necessary data to evaluate the protectiveness of remedial actions. As described in Chap. 2, two types of remedial action are proposed for EFPC floodplain soils: removal of surface soil at two locations with $>400 \mathrm{ppm}$ total mercury and no action everywhere else (DOE 1995b).

The objectives of the PMP for EFPC floodplain soil and associated biota differ for the two types of remedial action. At those locations where surface soil is going to be remociated, the objectives of the PMP are:

1. to detect changes in the exposure of terrestrial biota to soil mercury as the site recovers from remediation; and

2. to detect possible unexpected effects of the remedial action on ecological receptors.

At those locations where no action will be taken, the objectives of the PMP are:

1. to determine if the RG is protective of biota;

2. to detect increases in exposure of terrestrial biota to soil mercury resulting from environmental changes; and

3. to detect increases in adverse effects correlated with exposure to soil mercury should exposure increase.

For both types of location an additional objective is: to clarify the fraction of mercury in biota that is methylated. This information will reduce the uncertainty about exposures of predators to methylmercury in their prey and thus reduce uncertainty about the protectiveness of remediation.

Both sets of objectives involve monitoring exposure and effects. The similarity of objectives allows identical monitoring endpoints at both remediated and unremediated sites.

\subsubsection{Monitoring endpoints}

The resources in the environment that will be evaluated in the EFPC floodplain soil monitoring program are here termed monitoring endpoints. Monitoring endpoints differ from assessment endpoints, which are characteristics of the environment that are to be protected (EPA 1992b), because they do not specify a level of protection for the endpoint entities. Monitoring endpoints must be consistent, however, with the assessment endpoints for the EFPC BERA. The PMP's measurement endpoints must be able to support the evaluation of whether the remedial plan is protective of ecological resources, including the properties of endpoint entities specified in the BERA assessment endpoints. For example, the assessment endpoint for a BERA might be a $20 \%$ reduction in the species richness of the fish community in a lake. The corresponding monitoring endpoint would be changes in the species richness of the fish community.

For the EFPC BERA (DOE 1994a), the assessment endpoints for the terrestrial environment were protection of individuals of threatened and endangered species; protection of individual migratory birds; no reduction in the diversity, abundance, and distribution of the terrestrial animal community; and protection of individuals of terrestrial indicator organisms and their predators. As described in Chap. 3.4.2.1, the development of RGOs for mercury in soil focused on the characteristics of the EFPC environment that were most at risk of not being protected from adverse effects. These were mid-level predators, i.e., wrens and shrews, living on the floodplain and consuming soil-dwelling invertebrates. Therefore, mid-level predators and their soil-dwelling invertebrate prey are the endpoint entities for the EFPC soil monitoring program. 
Monitoring endpoints for the PMP for EFPC floodplain soil are changes in the exposure of and adverse effects on mid-level predators. These mid-level predators are residing on the floodplain and foraging on soil-dwelling invertebrate prey. An increase in a measure of exposure, such as the mercury body burdens of mid-level predators or their soil-dwelling invertebrate prey, e.g., earthworms and insects, would indicate an increase in the availability of total mercury or methylmercury in EFPC soil. It does not necessarily follow that an increase in mercury availability will cause an increase in adverse effects on survival or reproduction of receptors. If a measure of effects on mid-level predators is not included in the monitoring plan, then it will be necessary to assume that increases in exposure will produce an increase in adverse effects. Correlated increases in measures of both exposure and effects would indicate an increase in risk to mid-level predators from mercury in EFPC floodplain soil. Whether the observed level of effect exceeds the level of effect specified in the BERA assessment endpoint would need to be evaluated by a risk assessor.

The measurement endpoints for the EFPC soil monitoring program will provide data for the evaluation of the monitoring endpoints and will allow the objectives of the PMP to be met for EFPC soil and associated biota. The measurement endpoints are:

- Measurement endpoint 1: the concentrations of total mercury and methylmercury in composite samples of depurated earthworms from the EFPC floodplain.

- Measurement endpoint 2: the concentrations of total mercury and methylmercury in samples of individual mid-level predatory birds obtaining their diet predominately from the EFPC floodplain.

- Measurement endpoint 3: fertility and viability of offspring of mid-level predators reared on the EFPC floodplain relative to a reference site.

- Measurement endpoint 4 (conditional): if earthworm populations are so low that insufficient individuals can be collected for Measurement endpoint 1 , then the toxicity of EFPC floodplain soil to earthworms relative to a reference site and relative to a laboratory control will be evaluated.

Measurement endpoints 1 and 2 assess exposure; endpoints 3 and 4 assess effects.

No one of these measurement endpoints suffices to evaluate the protectiveness and potential impacts of remedial actions for EFPC floodplain soil. Together they can indicate changes in exposure to mercury in soil and correlated effects on mid-level predators in both remediated and unremediated areas of the EFPC floodplain.

\subsubsection{Monitoring Endpoint Organisms}

Endpoint organisms for the EFPC PMP must meet certain specifications. The endpoint organisms should be small animals that are restricted to the floodplain and come in contact directly or indirectly with contaminants in soil. In addition, endpoint organisms should be relatively abundant on the floodplain and neither threatened nor endangered with extinction. They should also be easily sampled. Endpoint organisms should be consistent with the endpoint entities in the EFPC BERA assessment endpoints.

The endpoint organisms for the EFPC soil monitoring program are earthworms and the European starling (Sturnus vulgaris). Both meet all the specifications. For example, earthworms are abundant on the floodplain, are easily sampled, ingest soil, and are not threatened or endangered. In 
addition, they are consumed by mid-level predators, like shrews and songbirds. Starlings are small predatory songbirds that, like Carolina wrens [the species used to derive RGOs for mercury in EFPC soil (DOE 1994a)], feed on soil-dwelling invertebrates, especially in the spring when they are rearing young. Starlings are relatively abundant on or near the EFPC floodplain and are ubiquitous in the surrounding area. They can be induced to nest at predetermined locations by providing nest boxes (Kendall et al. 1989). It is expected that starlings will forage in the immediate vicinity of the nest box while they are feeding nestlings, and these nestlings will thus be exposed predominantly to food from the floodplain. While adult starlings do not necessarily reside permanently on the floodplain, nestlings are restricted to the floodplain prior to fledging. Sampling young starlings from nest boxes prior to fledging is relatively easy and should ensure that the entire body burden of mercury in their tissue results from exposure to mercury from EFPC soil.

Short-tailed shrews and Carolina wrens, the other mid-level predators for which RGOs were derived, are not suitable as endpoint organisms for the EFPC PMP. For example, shrews are not easily sampled selectively. Carolina wrens, as natural components of the floodplain fauna, warrant protection from the lethal sampling required to measure mercury body burdens. Starlings, on the other hand, do not merit special concern and are therefore the preferred representative of mid-level predators of soil-dwelling invertebrates for the EFPC soil monitoring program.

\subsubsection{Body burden analysis}

All tissues collected will be analyzed for total mercury and methylmercury. Because soil ingested by earthworms may have high concentrations of mercury that is not biologically available, is presence can interfere with evaluation of earthworm body burdens and subsequent exposure of predators. Therefore, depurated earthworms will be analyzed to determine the body burden that is not attributable to ingested soil. Earthworms will be collected from an area of known size at each sampling location, depurated, and composited for tissue analysis (Measurement endpoint 1). Starling eggs and nestlings will be collected and their tissues analyzed (Measurement endpoint 2).

\subsubsection{Population data}

During sampling of starlings for body burden analyses, reproductive success of starlings will be monitored by counting the number of eggs and offspring in starling nest boxes (Measurement endpoint 3).

\subsubsection{Toxicity testing}

The toxicity of EFPC soil to earthworms (Measurement endpoint 4) will be tested if insufficient earthworms can be obtained for measurement of mercury body burdens.

\subsubsection{Monitoring Locations}

Specifications and locations for the EFPC soil monitoring program are included in step 4 of the DQO process (Chap. 2.3.4) and are discussed in the following subsections.

\subsubsection{Specifications for selection}

EFPC soil monitoring locations should be chosen to meet the objectives of the EFPC PMP: evaluating protectiveness and possible adverse impacts of soil removal and revegetation at remediated locations and evaluating the protectiveness of the decision not to remediate at locations with mercury 
concentrations $<400 \mathrm{mg} / \mathrm{kg}$. In addition to the two locations that will be remediated, two unremediated locations will be monitored. Unremediated locations should be representative of areas on the EFPC floodplain with a range of soil mercury concentrations. For example, an unremediated location with mercury levels between 200 and $400 \mathrm{mg} / \mathrm{kg}$ would show the effects of leaving in place concentrations of mercury above the ecological risk-based RGO. Locations with $<200 \mathrm{mg} / \mathrm{kg}$ soil mercury will provide a comparison to remediated sites and more highly contaminated unremediated sites.

Monitoring sites at unremediated locations should not be more likely to experience natural and anthropogenic alterations of physical conditions than are other areas on the floodplain. Locations should be attractive to European starlings and have suitable food resources for successful rearing of young. Earthworm densities should be high enough to meet sampling requirements. Sampling locations should be easily accessible to the sampling team.

\subsubsection{Monitoring locations}

Four locations on the EFPC floodplain will be used for the EFPC soil monitoring program. The monitoring locations should be in the EFPC floodplain near EFK 22, EFK 17.5, EFK 14 and EFK 10, adjacent to or near current BMAP EFPC and EFPC RI biological sampling sites (Fig. 4.1, Table 4.2). The two sites that will be remediated are the NOAA site and the Bruner site, located, respectively, near EFK 21.9 and EFK 17.5. Also, these are near EFPC RI biological sampling sites 1 and 3, respectively. Site EFK 14, on the Jackson farm and upstream of the Oak Ridge Sewage Treatment Plant, has maximum levels of mercury in soil below the ecological RGO, between $50 \mathrm{mg} / \mathrm{kg}$ and $200 \mathrm{mg} / \mathrm{kg}$. Site EFK 10, near the Grand Cove subdivision and EFPC RI biological sampling site 4, has maximum levels of mercury in soil above the ecological RGO but less than $400 \mathrm{mg} / \mathrm{kg}$.

\subsubsection{Reference monitoring site}

An uncontaminated location will provide reference background information for all measurement endpoints. The monitoring reference site will be located on the ORR near the log cabin at Freels bend, a site that is suitable for placement of nest boxes and is outside the EFPC floodplain. The same samples and measurements will be taken at this site as at the monitoring sites in the EFPC floodplain.

\subsubsection{Monitoring Schedule}

The monitoring schedule is included in step 4 of the DQO process (Chap. 2.3.4). Baseline monitoring was begun in the winter of 1996, before remediation has begun. Postremediation sampling will be done annually after remediation has been completed.

Soil samples will be collected during the first earthworm samples are taken. Additional soil samples will not be required at any site unless the results of tissue analyses indicate that the exposure of earthworms or starlings to methylmercury has increased from the time of the baseline sampling and the mean methylmercury body burdens in earthworms at that site exceed $0.012 \mathrm{mg} / \mathrm{kg}$, the dietary benchmark for birds, adjusted to the body weight of the starling (Opresko, Sample, and Suter 1994). Additional soil samples will be required to determine whether methylmercury production in soil has increased at the site and will be taken during the subsequent year's sampling.

Starling eggs and (Sturnus vulgaris) will be collected from nest boxes annually during the spring (early April-May). Sampling of broods will occur prior to fledging, which occurs over a 12to 21-d period following the onset of egg laying. From one brood, three eggs and three nestlings (from different nestboxes) will be sampled at each site. If the starlings produce two broods in a season, reproductive success for each brood will be assessed, but only the first brood will be sampled. 


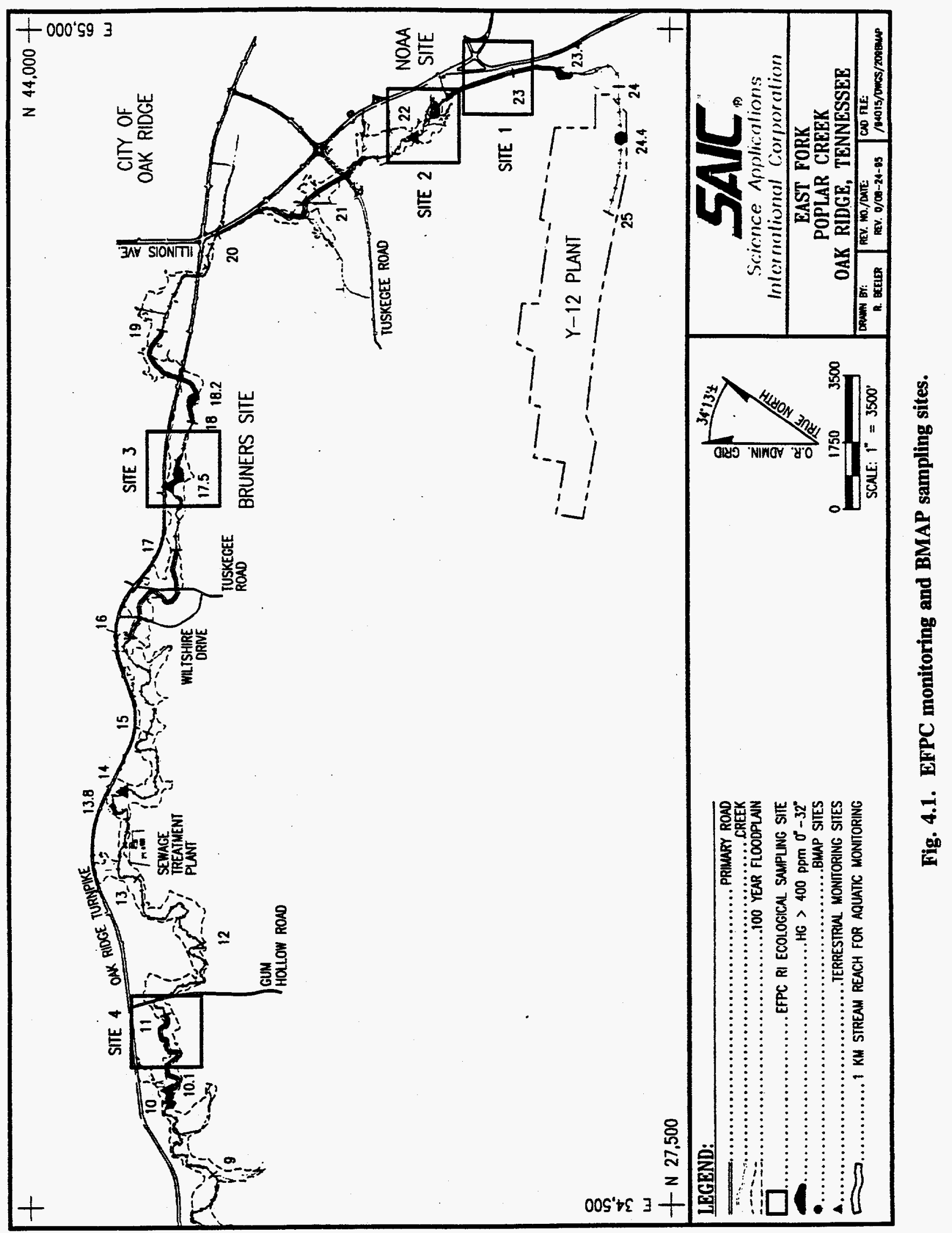


Table 4.2. Terrestrial sampling locations and numbers of samples for BMAP and PMP

\begin{tabular}{|c|c|c|c|c|c|}
\hline Site & Purpose & Medium & $\begin{array}{l}\text { Approximate } \\
\text { location } \\
\end{array}$ & $\begin{array}{l}\text { Samples for } \\
\text { BMAP }\end{array}$ & $\begin{array}{l}\text { Samples for } \\
\text { PMP only }\end{array}$ \\
\hline \multirow[t]{2}{*}{1} & \multirow{2}{*}{$\begin{array}{l}\text { Monitor } \\
\text { effects of } \\
\text { removals at } \\
\text { NOAA site }\end{array}$} & Soil & $\begin{array}{l}\text { E 63000, N } 33350 \\
\text { (near EFK 22.2) }\end{array}$ & None & $\begin{array}{l}\text { 1, during } \\
\text { earthworm } \\
\text { sampling }\end{array}$ \\
\hline & & $\begin{array}{l}\text { Earthworm, } \\
\text { starling }\end{array}$ & $\begin{array}{l}\text { E } 63000, N 33350 \\
\text { (near EFK 22.2) }\end{array}$ & None & $\begin{array}{l}5 \text { each } \\
\text { earthworms, eggs, } \\
\text { and nestlings per } \\
\text { year }\end{array}$ \\
\hline \multirow[t]{2}{*}{2} & \multirow{2}{*}{$\begin{array}{l}\text { Monitor } \\
\text { effects of } \\
\text { removals at } \\
\text { Bruner site }\end{array}$} & Soil & $\begin{array}{l}\text { E } 53300, \text { N } 39800 \\
\text { (near EFK 17.6) }\end{array}$ & None & $\begin{array}{l}\text { 1, during } \\
\text { earthworm } \\
\text { sampling }\end{array}$ \\
\hline & & $\begin{array}{l}\text { Earthworm, } \\
\text { starling }\end{array}$ & $\begin{array}{l}\text { E } 53300, N 39800 \\
\text { (near EFK 17.6) }\end{array}$ & None & $\begin{array}{l}5 \text { each } \\
\text { earthworms, eggs, } \\
\text { and nestlings per } \\
\text { year }\end{array}$ \\
\hline \multirow[t]{2}{*}{3} & \multirow{2}{*}{$\begin{array}{l}\text { Confirm lack } \\
\text { of effects at } \\
\text { exposure } \\
>50 \text { ppm, } \\
<200 \text { ppm }\end{array}$} & Soil & $\begin{array}{l}\text { E 45200, N 40800 } \\
\text { (near EFK 14.3) }\end{array}$ & None & $\begin{array}{l}1 \text {, during } \\
\text { earthworm } \\
\text { sampling }\end{array}$ \\
\hline & & $\begin{array}{l}\text { Earthworm, } \\
\text { starling }\end{array}$ & $\begin{array}{l}\text { E 45200, N 40800 } \\
\text { (near EFK 14.3) }\end{array}$ & None & $\begin{array}{l}5 \text { each } \\
\text { earthworms, eggs, } \\
\text { and nestlings per } \\
\text { year }\end{array}$ \\
\hline \multirow[t]{2}{*}{4} & \multirow{2}{*}{$\begin{array}{l}\text { Confirm lack } \\
\text { of effects at } \\
\text { exposure } \\
>200 \text { ppm, } \\
<400 \text { ppm }\end{array}$} & Soil & $\begin{array}{l}\text { E } 37500, N 40350 \\
\text { (near EFK 10.1) }\end{array}$ & None & $\begin{array}{l}1 \text {, during } \\
\text { earthworm } \\
\text { sampling }\end{array}$ \\
\hline & & $\begin{array}{l}\text { Earthworm, } \\
\text { starling }\end{array}$ & $\begin{array}{l}\text { E } 37500, N 40350 \\
\text { (near EFK 10.1) }\end{array}$ & None & $\begin{array}{l}5 \text { each } \\
\text { earthworms, eggs, } \\
\text { and nestlings per } \\
\text { year }\end{array}$ \\
\hline \multirow[t]{2}{*}{$5 a$} & \multirow[t]{2}{*}{$\begin{array}{l}\text { Reference } \\
\text { site }\end{array}$} & Soil & $\begin{array}{l}\text { Freels Bend, on } \\
\text { ORR }\end{array}$ & None & $\begin{array}{l}\text { 1, during } \\
\text { earthworm } \\
\text { sampling }\end{array}$ \\
\hline & & $\begin{array}{l}\text { Earthworm, } \\
\text { starling }\end{array}$ & $\begin{array}{l}\text { Freels Bend, on } \\
\text { ORR }\end{array}$ & None & $\begin{array}{l}5 \text { each } \\
\text { earthworms, eggs, } \\
\text { and nestlings per } \\
\text { year }\end{array}$ \\
\hline
\end{tabular}




\subsubsection{Sampling and Analytical Methods}

\subsubsection{Specifications for selection}

Sampling and analytical methods should be as close to EFPC RI sampling and analysis methods as possible for comparability.

\subsubsection{Field sampling}

Field sampling of soils will follow relevant technical procedures found in ES/ESH/INT-14: Environmental Surveillance Quality Control Program manual. Field sampling of earthworms and birds will follow relevant technical procedures described in ESQAP-96-0201, Rev. 0: Biological Monitoring and Abatement Program Quality Assurance Plan, Bioaccumulation Monitoring Terrestrial.

Soil will be sampled according to methods similar to those used in the EFPC RI. Soil samples will be collected to a maximum depth of $48 \mathrm{~cm}(18 \mathrm{in}$.) with a hand-operated, trier-type device (Backsaver) following procedure TP-303-8 or with a 7.5-cm (3-in) bucket hand auger in accordance with procedure ESP-303-1, Rev.1. Each sample will be placed in a clean stainless steel bowl and composited with a stainless steel spoon. A subsample will then be placed in a sample bottle provided by the laboratory, placed in a cooler, and sent to the laboratory at the end of the day for analysis of total mercury and methylmercury.

The procedure for earthworm sampling will be to use a mustard solution (Gunn 1992) as an expellant (Bechtel 1994). A mustard and water suspension will be applied slowly to the ground surface using a watering can to obtain even spread and minimal ponding. Surfacing earthworms will be collected with forceps until no additional earthworms emerge ( 20 to $25 \mathrm{~min})$. Earthworms will be rinsed in the field with deionized water to remove soil and expellant, and put in a Petri dish which is then sealed and put in a cooler. It is essential that all earthworms be kept moist, intact, and alive, and that handling be minimized. Parameters recorded for each earthworm will include sample location, sample site, date collected, total weight of earthworms collected at each site (measured in the laboratory), presence of clitellum, and general physical condition including overt signs of lesions or other abnormalities. All earthworms will be maintained in the laboratory at room temperature for $1 \mathrm{~d}$ to allow depuration (voiding of intestinal contents). Three composite samples from each EFPC site and the reference site will be analyzed for total mercury and methylmercury.

Nest-box studies of starlings will follow the published descriptions of the methods used by Kendall et al. (1989) to study starlings exposed to pesticides under field conditions.

\subsubsection{Laboratory analysis of total mercury and methylmercury}

Soil and tissue samples (Measurement endpoints 1 and 2) will be sent to a qualified laboratory for analysis of total mercury and methylmercury. One gram of sample is sufficient for analysis. Special Analytical Services will be required, e.g., ethylation of total mercury followed by gas chromatography and detection by atomic fluorescence is recommended for methylmercury analyses. Detection limits of this method are $0.1 \mu \mathrm{g} / \mathrm{kg}$ for total mercury and $0.05 \mu \mathrm{g} / \mathrm{kg}$ (as mercury) for methylmercury. 


\subsubsection{Toxicity testing}

Toxicity tests on soil (Measurement endpoint 4) are required for the EFPC PMP when insufficient earthworms are present in EFPC soils to meet the requirements of the earthworm-body burden analysis. Technical procedures for toxicity tests of soils using earthworms are described in ESQAP-95-0720, Rev. 0: Biological Monitoring and Abatement Program Quality Assurance Plan, Soil Toxicity Testing.

\subsubsection{Decision Rules}

Decision rules comprise step 5 of the DQO process (Chap. 2.3.5). If postremediation UCL body burdens at remediated sites are consistently above baseline UCL body burden at remediated sites, conclude that remediation has mobilized mercury so that it is more bioavailable than before remediation; continue monitoring for five years. If at the end of five years body burdens are above preremediation and reference levels, evaluate the need for further remediation. If postremediation body burdens are at or below baseline level for two successive years, monitoring may be discontinued until the fifth year after remediation.

If LCL reproductive success of starlings (fraction of eggs hatched and fraction of young fledged) is consistently lower at unremediated sites than at the reference site and, as a positive control, if UCL reproductive success is consistently higher at the remediated sites and the reference site postremediation than at baseline, conclude that residual mercury in soil may have an adverse impact on vermivorous songbirds. Continue monitoring for five years. If UCL body burden of methylmercury in starlings is above $2.5 \mathrm{mg} / \mathrm{kg}$ for two years, conclude that residual mercury in soil at that site may have an adverse impact on terrestrial predators. If no impacts are observed for two successive years, monitoring may be discontinued upon agreement by investigators, DOE, and the regulators.

\subsection{MONITORING SEDIMENT, SURFACE WATER, AND FISH}

The elements of the EFPC PMP that pertain to sediment, surface water, and fish are described below. Because the RGOs for mercury in EFPC sediment are based on the exposure of aquatic biota (e.g., fish) to mercury, the PMP for EFPC sediment is identical to the monitoring program for surface water and biota associated with surface water. Therefore, the monitoring programs for sediment and surface water are described together in this section. The recommendations for monitoring sediment, surface water, and associated biota are summarized in Table 4.3.

The monitoring program for the EFPC surface water overlaps existing and proposed EFPC monitoring components of the Y-12 BMAP. Where possible, monitoring data will be shared by the two programs. Sampling analysis now required by both programs would need to be continued for the EFPC PMP if BMAP were discontinued. 
Table 4.3. Selection specifications and recommendations for monitoring of sediment, surface water, and fish

\begin{tabular}{|c|c|}
\hline Selection criteria & Recommendations \\
\hline $\begin{array}{l}\text { Analytes: Mercury is the COC in sediment and } \\
\text { surface water. Methylmercury is the form of } \\
\text { mercury of most concern for ecological } \\
\text { receptors. }\end{array}$ & $\begin{array}{l}\text { Recommended analytes: Total and methylmercury should be } \\
\text { analyzed in all matrices. }\end{array}$ \\
\hline $\begin{array}{l}\text { Matrices: The matrices analyzed will be } \\
\text { relevant to the ecological exposures to mercury, } \\
\text { which accumulates through the food chain, and } \\
\text { to the sediment RGO, whose most sensitive } \\
\text { point is entry of methylmercury into the food } \\
\text { chain. }\end{array}$ & $\begin{array}{l}\text { Recommended matrices: Sediment and surface water mercury } \\
\text { concentration and toxicity measurements will be made. Both } \\
\text { unfiltered and filtered surface water will be analyzed. Whole } \\
\text { body measurements of mercury in central stonerollers, striped } \\
\text { shiners, and redbreast sunfish will be made to delineate } \\
\text { exposures at a low trophic level (stonerollers) where most } \\
\text { incorporated mercury has been shown to be inorganic and at } \\
\text { higher trophic levels (shiners and sunfish) where most } \\
\text { incorporated mercury has been shown to be methylated. }\end{array}$ \\
\hline $\begin{array}{l}\text { Where to sample: Locations will represent } \\
\text { range of mercury exposure conditions in surface } \\
\text { water along the length of the creek and coincide } \\
\text { with BMAP samping where possible. }\end{array}$ & $\begin{array}{l}\text { Recommended locations: Sediment samples will be taken } \\
\text { upstream and downstream of remediated sites and near } \\
\text { nonremediated sites with elevated soil mercury concentrations. } \\
\text { Surface water and fish samples will be taken from all sampling } \\
\text { locations used by the Y-12 BMAP for its studies. }\end{array}$ \\
\hline $\begin{array}{l}\text { When to sample: Should sample when exposed } \\
\text { biota will reflect seasonal changes in exposure. } \\
\text { Should sample after the warm season to see any } \\
\text { potential seasonal increases in mercury } \\
\text { methylation in biota. }\end{array}$ & $\begin{array}{l}\text { Recommended times: Samples should be taken once or twice } \\
\text { annually, during May and/or November/December, as } \\
\text { specified by BMAP. }\end{array}$ \\
\hline
\end{tabular}




\subsubsection{Monitoring Rationale}

Monitoring of sediment, surface water, and associated biota in EFPC is necessary to evaluate the protectiveness of the remedial plan. The chosen RGO for mercury in EFPC sediment is $108 \mathrm{mg}$ total mercury $/ \mathrm{kg}$ sediment. This RGO is based on protection of sediment-dwelling aquatic organisms exposed to methylmercury in sediment pore-water (DOE 1995c). No measurements of sediments in EFPC showed mercury concentrations $>96$ ppm; therefore, no sediments will be remediated.

The RGO for mercury in sediment is also predicted to protect piscivorous predators exposed to mercury-contaminated fish which were exposed to mercury in surface water and their food. Contamination of food items for fish results from exposure to mercury in sediment and surface water (DOE 1995b). This chain of predictions is based on assumed fractions of methylmercury to total mercury in both sediment and the diets of fish and their predators. There is sufficient uncertainty about these variables that it is prudent to monitor the direct and indirect exposure of piscivorous predators to mercury in sediment and surface water. Moreover, the nature of the mercury that continues to be released into the floodplain from the Y-12 Plant, the environmental conditions influencing mercury methylation rates and other environmental factors could change, thereby increasing the exposure of biota to mercury. If the exposure of biota to the different forms of mercury increases enough to cause adverse effects, the decision not to remediate sediments would need to be reevaluated after two years or at the end of the five-year monitoring program. Monitoring will permit this evaluation to be made. Decision rules (DQO step 5, Chap. 2.3.5) are used to make these decisions.

Mercury or methylmercury in EFPC sediment may be directly toxic to benthic invertebrates, or they may leach into overlying surface water where they may be toxic to fish and other aquatic biota. Releases of mercury to EFPC surface water from the Y-12 Plant are, however, currently greater than the modeled releases from sediment (DOE 1994b). Thus, it is prudent to evaluate whether releases from sediment could contribute significantly to mercury concentrations in surface water and to the exposures of biota after Y-12 Plant releases to water are further reduced. Measuring concentrations of methylmercury in filtered surface water will provide an indication of exposure to mercury contaminants potentially derived from sediment.

Removal of soils with $>400$ ppm from two terrestrial locations along EFPC could cause soil with elevated mercury levels to erode into the creek. Monitoring of sediment, surface water, and associated biota immediately downstream of these two locations will allow evaluation of possible unexpected effects of remediation on ecological receptors.

\subsubsection{Monitoring goals}

The goal of the monitoring program for EFPC sediment, surface water, and associated biota is to provide the necessary data to evaluate the protectiveness of the remedial plan. As described in Chap. 2, no sediments will be removed from EFPC (DOE 1995b). However, sections of EFPC downstream of terrestrial sites that are going to be remediated may experience impacts from the process of excavating soil with $>400 \mathrm{mg} / \mathrm{kg}$ total mercury.

The objectives of the monitoring program for EFPC sediment, surface water, and associated biota differ by location. At those locations immediately downstream of where surface soil is going to be remediated, the objectives of the EFPC PMP are:

1. to detect changes in the exposure of aquatic and sediment-associated biota to mercury as the site recovers from remediation; and 
2. to detect possible unexpected effects of the remedial action on ecological receptors living in the creek.

Elsewhere in EFPC, the objectives of the PMP are:

1. to detect increases in exposure of aquatic and sediment-associated biota to sediment mercury resulting from environmental changes; and

2. to detect increases in adverse effects correlated with exposure to sediment mercury should exposure increase.

Both sets of objectives require monitoring both exposure and effects. The similarity of objectives allows identical monitoring endpoints at both remediated and unremediated sites.

\subsubsection{Monitoring endpoints}

The monitoring endpoints for the EFPC sediment and surface water monitoring program are resources in the sediment and aquatic environments that will be evaluated to indicate whether the remedial plan is protective of ecological resources. The PMP's measurement endpoints must be able to support the evaluation of whether the specified levels of effect on the properties of the BERA assessment endpoint entities are exceeded.

For the EFPC BERA (DOE 1994a), the assessment endpoints for the aquatic environment were protection of individuals of threatened and endangered species, protection of individual migratory waterfowl, no degradation of the fish community, and protection of individuals of aquatic indicator organisms and their predators. The development of RGOs for mercury in sediment focused on the characteristics of the EFPC environment that were most at risk of not being protected from adverse effects. These were sediment-dwelling biota (e.g., chironomids), fish (e.g., sunfish), and piscivorous predators (i.e., herons, kingfishers, and mink). These endpoint entities are potential subjects of the monitoring endpoints for the EFPC sediment and surface water monitoring aspects of the PMP.

The monitoring endpoints for EFPC sediment and surface water are changes in the exposure of and adverse effects on the aquatic biota and piscivorous predators exposed directly or indirectly to mercury in sediment and surface water. An increase in mercury availability will not necessarily cause an increase in adverse effects on receptors. Likewise, an increase in adverse effects does not necessarily mean that ecological receptors experienced an increased exposure to mercury. Correlated increases in both exposure and adverse effects on survival and reproduction would indicate an increase in risk to aquatic biota and piscivorous predators from mercury in EFPC sediment and surface water relative to the reference measurements. Decision rules specified in Chap. 4.2.6 will be used to determine whether observed effects exceed monitoring endpoints.

Monitoring exposure and effects is not feasible for all ecological receptors that are potentially at risk from mercury in EFPC sediment and surface water. If ecological receptors are not monitored for evidence of increased effects, then it is necessary to assume that increases in exposure will produce an increase in adverse effects. If exposure is not monitored, then it may be necessary to assume that an increase in effects is produced by an increase in exposure, unless there is evidence of other causes at work. The monitoring plan for EFPC sediment and surface water includes a mixture of exposure and effects monitoring endpoints for ecological receptors: sediment-dwelling organisms, aquatic biota, and piscivorous predators. 
Monitoring of effects on sediment-dwelling organisms is required to evaluate the monitoring endpoint for those organisms exposed directly to sediment or sediment pore water. Sedimentdwelling organisms exposed to methylmercury in sediment pore water had the lowest RGO for ecological receptors (DOE 1995d). Monitoring changes in exposure of sediment-dwelling organisms to mercury in EFPC sediments by sampling and analyzing tissues of those organisms is not proposed because of the difficulty of obtaining sufficient tissue for analysis. Exposure of sediment-dwelling organisms is assumed to be correlated with sediment concentrations, the toxicity of which will be tested. Correlated changes in toxicity and sediment or sediment pore water concentrations, or tests confirming mercury as the source of toxicity would be required to evaluate the monitoring endpoint for sediment-dwelling biota.

Monitoring of body burdens in or effects on piscivorous predator populations is not proposed for the EFPC PMP. Mink and herons range widely over the EFPC floodplain and the surrounding area and only a small number of individuals are likely to be present on the floodplain at any one time. The number of breeding kingfisher pairs residing along the creek is likely to be small and disturbing or destroying these birds is undesirable. Thus, an increase in the concentration of mercury in their aquatic fish prey is assumed to cause an increase in exposure of and adverse effects on piscivorous predators.

The sediment and surface water monitoring program includes monitoring exposure of and effects on aquatic biota exposed indirectly to sediment mercury by way of ingestion of sedimentdwelling invertebrates or direct uptake from surface water. An increase in the mercury body burden of aquatic biota would indicate an increase in the availability of total mercury or methylmercury in EFPC sediment or surface water. Such an increase may be caused, in part, by temporal shifts in diet, and this too will need to be taken into account. Correlated increases in exposure (body burden in fish) and effects (toxicity to Hyalella or Ceriodaphnia) would indicate an increase in risk to aquatic biota and piscivorous predators from mercury in EFPC sediment or surface water. If there were no concomitant increase in dissolved mercury in surface water, then the increase in exposure and effects could be attributable to an increase in the mercury content of their prey resulting from an increase in the availability of mercury in sediment or sediment pore-water.

The measurement endpoints for the EFPC sediment and surface water monitoring program are thus direct or indirect indicators of increased exposure to and adverse effects on sediment-dwelling organisms, aquatic biota, and piscivorous predators from mercury in EFPC sediment and surface water. These measurement endpoints will allow the two sets of objectives of the PMP to be met for EFPC sediment, surface water, and associated biota. The measurement endpoints are:

- Measurement endpoint 5: the concentrations of total mercury and methylmercury in composite samples of species of fish that are eaten by piscivorous predators.

- Measurement endpoint 6: the toxicity of EFPC sediment to sediment-dwelling organisms relative to sediments from a reference site and relative to a laboratory control.

- Measurement endpoint 7: the toxicity of EFPC surface water to aquatic biota relative to surface water from a reference site and relative to a laboratory control.

- Measurement endpoint 8: the concentrations of total mercury and methylmercury in surface water. 
Measurement endpoint 5 assesses exposure; measurement endpoints 6 and 7 assess effects. Measurement endpoint 8 evaluates whether the concentration of total mercury and methylmercury in water has increased sufficiently to cause the observed changes in measurement endpoint 5.

No one of these measurement endpoints suffices to evaluate the protectiveness of the remedial plan for EFPC sediment and surface water and potential impacts on aquatic receptors from remedial actions for EFPC soil. Together they can detect changes in exposure to mercury and correlated effects on sediment-dwelling biota, aquatic biota (e.g., fish), and piscivorous predators. This evaluation will also require an estimate or estimates of the BCF for fishes exposed to mercury in surface water. Surface water samples will be collected and analyzed as part of BMAP. Coordinated monitoring of mercury concentrations in EFPC fish and surface water may result in improved site-specific estimates of BCFs for evaluating the monitoring endpoints for sediment and surface water.

\subsubsection{Monitoring Endpoint Organisms}

Endpoint organisms for the EFPC PMP must meet certain specifications. The endpoint organisms should be restricted to the creek and come in direct or indirect contact with mercury in sediment or surface water. They should not come in direct contact with contaminants in soil in the terrestrial environment. In addition, endpoint organisms should be relatively abundant and neither threatened nor endangered with extinction. They should also be easily sampled.

The BMAP will collect three species of fish: central stonerollers (Campostoma anomalum), striped shiners (Luxilus chrysocephalus), and redbreast sunfish (Lepomis auritus). All three species are abundant in the creek, are easily sampled, are exposed to surface water, and are not threatened nor endangered. Monitoring these three species of fish may help evaluate whether increases in exposure of fish to mercury result from an increase in uptake of dissolved mercury from surface water or an increase in the availability of mercury in sediment. These fish, to a large degree, eat different types of food, but are all exposed to surface water. Stonerollers ingest primarily periphyton scraped from rocks (Etnier and Starnes 1993). Striped shiners have been reported to feed heavily on sediment-dwelling invertebrates (Etnier and Starnes 1993), and redbreast eat primarily macroorganisms living on the bottom, in the water column, or found on the surface of the water, e.g., terrestrial insects and aquatic insect larvae (Etnier and Starnes 1993). If all species show an increase in methylmercury body burden, a dissolved source may be indicated rather than an increase in the flux of mercury from sediment to food to fish. If methylmercury body burdens increase in redbreast and shiners but do not increase in stonerollers, then an increase in the flux of mercury from sediment to invertebrate food to fish may be indicated as opposed to an increase in the availability or concentration of methylmercury in water.

Redbreast sunfish are intensively monitored by BMAP to detect spatial and temporal trends in mercury and PCB contamination in EFPC, and will be used as the primary species to detect change in fish mercury concentrations for the EFPC PMP. Stonerollers and striped shiners are proposed to be monitored at a more limited number of sites than sunfish. To obtain the methylmercury and total mercury concentrations in forage fish at the sites needed for the EFPC PMP, subsamples of BMAP-collected forage fish will be taken where possible and some additional collections will be conducted for the EFPC PMP. BMAP historic data for mercury content of redbreast sunfish in EFPC consist of analyses of muscle tissue for total mercury. For the EFPC PMP, information is necessary to extrapolate from BMAP data to estimated concentrations of total mercury and methyl mercury in whole bodies. 


\subsubsection{Body burden analysis}

On a one time basis, methyl mercury and total mercury in whole bodies of sunfish will be compared to the concentrations of mercury in sunfish filets so that the BMAP filet data can be used to evaluate ecological concerns. This effort will coincide with the annual forage fish monitoring so that methyl mercury and total mercury concentrations can be compared among the three species. To evaluate filet vs. whole body concentrations in sunfish, three of the eight redbreast sunfish each site will be divided into two portions. One portion will consist of a small amount of fish muscle that will be weighed and analyzed to provide the filet concentration. The entire remaining portion will provide the whole body concentration (the filet data will be added back into the whole-body total).

The whole bodies of striped shiners and central stonerollers will be collected from five sites in EFPC and a reference stream and composited (Measurement endpoint 6). Whole body concentrations in fish will suffice to meet the DQOs for the monitoring program. Three composite samples of 10 fish of each species will be collected; one composite of each species will be analyzed for total and methyl mercury, the other two composite samples will be archived. An estimate of the variability in mercury concentrations between composites at each site will be attained by analyzing a very small number of the "archived" composites, and by assessing the total mercury variability observed in the three composites of striped shiners collected at each BMAP site. If there are large differences in fish mercury concentrations observed in single composite samples before and after remediation, additional archived composites could be analyzed to more adequately evaluate the temporal change. The need for analysis of methyl mercury in forage fish will be reevaluated after sufficient data is collected to evaluate whether there are any significant changes in the mercury fractions after remediation. Whole body concentrations in fish will suffice to meet the DQOs for the monitoring program.

\subsubsection{Toxicity testing}

Toxicity tests of bulk sediments and surface water are required for the EFPC PMP (Measurement endpoints 6 and 7). Toxicity tests of Hyalella azteca (a freshwater scud) exposed to bulk sediment will be used to evaluate the potential for harm to sediment and surface water biota from contaminants derived from the remediated and unremediated sites described above. Surface water is currently being tested for toxicity by BMAP, using a Ceriodaphnia dubia toxicity test. Toxicity testing of sediment and surface water would have to continue for the PMP if BMAP were to cease.

\subsubsection{Monitoring Locations}

Specifications and locations for the EFPC sediment monitoring program are discussed in the following sections.

\subsubsection{Specifications for selection}

Sampling locations for EFPC sediment should be in sediment deposition areas that are easily accessible to the sampling team. Sampling areas for fish should be suitable for fish and should be easily accessible to the sampling team. Removal of soils with $>400 \mathrm{ppm}$ from two terrestrial locations along EFPC could potentially increase the risk to ecological receptors living in EFPC downstream of those locations. One mechanism for this is bank sloughing and erosion during remediation.

Monitoring of sediment in reaches immediately upstream and downstream of these two locations will allow evaluation of possible unexpected effects of remediation on ecological receptors. 
Reaches not immediately downstream of soil remediation should be representative of reaches throughout the EFPC and should not be more likely to experience natural and anthropogenic alterations of physical conditions than are other reaches.

\subsubsection{Sampling locations}

Four locations in EFPC are described for the EFPC PMP. All of these are near current BMAP sampling sites. The two sites that will be remediated, the NOAA site and the Bruner site, are located, respectively, near EFK 21.9 and EFK 17.5, and each of these is bracketed by an upstream and downstream sampling location. Two other sites were chosen to monitor the effects of unremediated floodplain soils on sediment and surface water. Sites where samples will be taken for BMAP and for the PMP are presented in Table 4.4.

Sediment will be sampled at or near EFK 22.6 and EFK 21.6 (NOAA site), EFK 17.9 and EFK 17.0 (Bruner site), EFK 14.3 (Jackson farm), EFK 10.0 (Grandcove Estates), and a reference site. Sediment toxicity tests will be conducted at these locations also. Fish bioaccumulation data from BMAP and used by the PMP will be from samples taken at EFK 23.4, EFK 18.2, EFK 13.8, and the reference site; an additional site will be added near EFK 21.6. Surface water sampling for analysis of total mercury and methyl mercury and for toxicity tests will be conducted at EFK 22.8, EFK 21.9, EFK 18.2, EFK 17.0, EFK 13.8, EFK 10.9, and a reference site. 
Table 4.4. Sediment and aquatic sampling locations and numbers of samples from BMAP and specifically for PMP

\begin{tabular}{|c|c|c|c|c|c|}
\hline Site & Purpose & Medium & $\begin{array}{l}\text { Approximate } \\
\text { location }\end{array}$ & $\begin{array}{l}\text { Samples from } \\
\text { BMAP }\end{array}$ & $\begin{array}{l}\text { Samples for } \\
\text { PMP only }\end{array}$ \\
\hline \multirow[t]{6}{*}{1} & \multirow{2}{*}{$\begin{array}{l}\text { Monitor } \\
\text { effects of } \\
\text { removals } \\
\text { at NOAA } \\
\text { site }\end{array}$} & Sediment & $\begin{array}{l}\text { Near EFK } \\
22.6\end{array}$ & None & $\begin{array}{l}1 \text { per event, twice } \\
\text { yearly }\end{array}$ \\
\hline & & Surface water & $\begin{array}{l}\text { BMAP site } \\
\text { EFK 22.8 }\end{array}$ & $\begin{array}{l}1 \text { per event, twice } \\
\text { yearly (unfiltered } \\
\text { water) }\end{array}$ & $\begin{array}{l}1 \text { per event, twice } \\
\text { yearly (filtered water) }\end{array}$ \\
\hline & \multirow[t]{4}{*}{. } & $\begin{array}{l}\text { Fish (redbreast } \\
\text { sunfish, striped } \\
\text { shiner, central } \\
\text { stoneroller) }\end{array}$ & $\begin{array}{l}\text { BMAP site at } \\
\text { EFK } 23.4\end{array}$ & $\begin{array}{l}8 \text { redbreast } \\
\text { sunfish each per } \\
\text { event, twice } \\
\text { yearly; } 3 \text { striped } \\
\text { shiner composites } \\
\text { annually. Both } \\
\text { analyzed for total } \\
\text { mercury. }\end{array}$ & $\begin{array}{l}3 \text { redbreast sunfish } \\
\text { splits per event on one } \\
\text { occasion in first year; } \\
\text { methylmercury analyses } \\
\text { of } 3 \text { striped shiner } \\
\text { composites; total } \\
\text { mercury and methyl- } \\
\text { mercury analyses of } 3 \\
\text { central stoneroller } \\
\text { composites annually, } \\
\text { from BMAP collection. }\end{array}$ \\
\hline & & Sediment & $\begin{array}{l}\text { Near EFK } \\
21.6\end{array}$ & None & $\begin{array}{l}1 \text { per event, twice } \\
\text { yearly }\end{array}$ \\
\hline & & Surface water & $\begin{array}{l}\text { Near EFK } \\
21.9\end{array}$ & $\begin{array}{l}1 \text { per event, twice } \\
\text { yearly (unfiltered } \\
\text { water) }\end{array}$ & $\begin{array}{l}1 \text { per event, twice } \\
\text { yearly (filtered water) }\end{array}$ \\
\hline & & $\begin{array}{l}\text { Fish (redbreast } \\
\text { sunfish, striped } \\
\text { shiner, central } \\
\text { stoneroller) }\end{array}$ & $\begin{array}{l}\text { Near EFK } \\
21.6\end{array}$ & None & $\begin{array}{l}\text { Total mercury analyses } \\
\text { of } 8 \text { redbreast sunfish } \\
\text { each per event, twice } \\
\text { yearly; on one occasion } \\
\text { in first year, } 3 \text { split for } \\
\text { whole-body/fillet } \\
\text { comparisons. Total } \\
\text { mercury and methyl- } \\
\text { mercury analyses of } 3 \\
\text { striped shiner } \\
\text { composites and } 3 \\
\text { central stoneroller } \\
\text { composites annually. }\end{array}$ \\
\hline \multirow[t]{2}{*}{2} & \multirow{2}{*}{$\begin{array}{l}\text { Monitor } \\
\text { effects of } \\
\text { removals } \\
\text { at Bruner } \\
\text { site }\end{array}$} & Sediment & $\begin{array}{l}\text { Near EFK } \\
17.9\end{array}$ & None & $\begin{array}{l}1 \text { per event, twice } \\
\text { yearly }\end{array}$ \\
\hline & & Surface water & $\begin{array}{l}\text { BMAP site at } \\
\text { EFK } 18.2\end{array}$ & $\begin{array}{l}1 \text { per event, twice } \\
\text { yearly (unfiltered } \\
\text { water) }\end{array}$ & $\begin{array}{l}1 \text { per event, twice } \\
\text { yearly (filtered water) }\end{array}$ \\
\hline
\end{tabular}


Table 4.4 (continued)

\begin{tabular}{|c|c|c|c|c|c|}
\hline Site & Purpose & Medium & $\begin{array}{l}\text { Approximate } \\
\text { location } \\
\end{array}$ & $\begin{array}{l}\text { Samples from } \\
\text { BMAP }\end{array}$ & $\begin{array}{l}\text { Samples for } \\
\text { PMP only }\end{array}$ \\
\hline & & $\begin{array}{l}\text { Fish (redbreast } \\
\text { sunfish, striped } \\
\text { shiner, central } \\
\text { stoneroller) }\end{array}$ & $\begin{array}{l}\text { BMAP site at } \\
\text { EFK } 18.2\end{array}$ & $\begin{array}{l}8 \text { redbreast } \\
\text { sunfish each per } \\
\text { event, twice } \\
\text { yearly; } 3 \text { striped } \\
\text { shiner composites } \\
\text { annually. Both } \\
\text { analyzed for total } \\
\text { mercury. }\end{array}$ & $\begin{array}{l}3 \text { redbreast sunfish } \\
\text { splits per event on one } \\
\text { occasion in first year; } \\
\text { methylmercury analyses } \\
\text { of } 3 \text { striped shiner } \\
\text { composites; total } \\
\text { mercury and methyl- } \\
\text { mercury analyses of } 3 \\
\text { central stoneroller } \\
\text { composites annually, } \\
\text { from BMAP collection. }\end{array}$ \\
\hline & & Sediment & $\begin{array}{l}\text { Near EFK } \\
17.0\end{array}$ & None & $\begin{array}{l}1 \text { per event, twice } \\
\text { yearly }\end{array}$ \\
\hline & & Surface water & $\begin{array}{l}\text { Near EFK } \\
17.0\end{array}$ & None & $\begin{array}{l}2 \text { per event, twice } \\
\text { yearly (unfiltered and } \\
\text { filtered water) }\end{array}$ \\
\hline \multirow[t]{2}{*}{3} & $\begin{array}{l}\text { Confirm } \\
\text { lack of } \\
\text { effects at } \\
\text { exposure } \\
>50 \\
\text { ppm, }\end{array}$ & Surface water & $\begin{array}{l}\text { BMAP site at } \\
\text { EFK } 13.8\end{array}$ & $\begin{array}{l}1 \text { per event, twice } \\
\text { yearly (unfiltered } \\
\text { water) }\end{array}$ & $\begin{array}{l}1 \text { per event, twice } \\
\text { yearly } \\
1 \text { per event, twice } \\
\text { yearly (filtered water) }\end{array}$ \\
\hline & $\begin{array}{l}<200 \\
\text { ppm }\end{array}$ & $\begin{array}{l}\text { Fish (redbreast } \\
\text { sunfish, central } \\
\text { stoneroller) }\end{array}$ & $\begin{array}{l}\text { BMAP site at } \\
\text { EFK } 13.8\end{array}$ & $\begin{array}{l}8 \text { redbreast } \\
\text { sunfish each per } \\
\text { event, twice } \\
\text { yearly; } 3 \text { striped } \\
\text { shiner composites } \\
\text { annually. Both } \\
\text { analyzed for total } \\
\text { mercury. }\end{array}$ & $\begin{array}{l}3 \text { redbreast sunfish } \\
\text { splits per event on one } \\
\text { occasion in first year; } \\
\text { methylmercury analyses } \\
\text { of } 3 \text { striped shiner } \\
\text { composites; total } \\
\text { mercury and methyl- } \\
\text { mercury analyses of } 3 \\
\text { central stoneroller } \\
\text { composites annually, } \\
\text { from BMAP collection. }\end{array}$ \\
\hline \multirow[t]{2}{*}{4} & $\begin{array}{l}\text { Confirm } \\
\text { lack of } \\
\text { effects at } \\
\text { exposure }\end{array}$ & Sediment & EFK 10.0 & None & $\begin{array}{l}1 \text { per event, twice } \\
\text { yearly }\end{array}$ \\
\hline & $\begin{array}{l}>200 \\
\text { ppm, } \\
<400 \\
\text { ppm }\end{array}$ & Surface water & $\begin{array}{l}\text { BMAP site at } \\
\text { EFK } 10.9\end{array}$ & $\begin{array}{l}1 \text { per event, twice } \\
\text { yearly (unfiltered } \\
\text { water) }\end{array}$ & $\begin{array}{l}1 \text { per event, twice } \\
\text { yearly (filtered water) }\end{array}$ \\
\hline $5 \mathbf{b}$ & $\begin{array}{l}\text { Reference } \\
\text { site }\end{array}$ & Sediment & $\begin{array}{l}\text { BMAP Hinds } \\
\text { Creek site }\end{array}$ & None & $\begin{array}{l}1 \text { per event, twice } \\
\text { yearly }\end{array}$ \\
\hline
\end{tabular}


Table 4.4 (continued)

\begin{tabular}{|c|c|c|c|c|c|}
\hline Site & Purpose & Medium & $\begin{array}{l}\text { Approximate } \\
\text { location }\end{array}$ & $\begin{array}{l}\text { Samples from } \\
\text { BMAP }\end{array}$ & $\begin{array}{l}\text { Samples for } \\
\text { PMP only }\end{array}$ \\
\hline & & Surface water & $\begin{array}{l}\text { BMAP Hinds } \\
\text { Creek site }\end{array}$ & $\begin{array}{l}1 \text { per event, twice } \\
\text { yearly (unfiltered } \\
\text { water) }\end{array}$ & $\begin{array}{l}1 \text { per event, twice } \\
\text { yearly (filtered water) }\end{array}$ \\
\hline & & $\begin{array}{l}\text { Fish (redbreast } \\
\text { sunfish, central } \\
\text { stoneroller) }\end{array}$ & $\begin{array}{l}\text { BMAP Hinds } \\
\text { Creek site }\end{array}$ & $\begin{array}{l}8 \text { redbreast } \\
\text { sunfish each per } \\
\text { event, twice } \\
\text { yearly; } 3 \text { striped } \\
\text { shiner composites } \\
\text { annually. Both } \\
\text { analyzed for total } \\
\text { mercury. }\end{array}$ & $\begin{array}{l}3 \text { redbreast sunfish } \\
\text { splits per event on one } \\
\text { occasion in first year; } \\
\text { methylmercury analyses } \\
\text { of } 3 \text { striped shiner } \\
\text { composites; total } \\
\text { mercury and methyl- } \\
\text { mercury analyses of } 3 \\
\text { central stoneroller } \\
\text { composites annually, } \\
\text { from BMAP collection. }\end{array}$ \\
\hline
\end{tabular}




\subsubsection{Reference monitoring site}

An uncontaminated location on Hinds Creek will provide reference background information for all sediment, surface water, and fish measurement endpoints. Hinds Creek is outside the EFPC floodplain and has substrate type, physiography, and surrounding land use that are similar to EFPC. Hinds Creek has been used as a reference site for BMAP and the EFPC RI biological sampling program. Reference locations on Hinds Creek currently being monitored by BMAP will continue to be sampled and one of these will be used as the reference site for the EFPC PMP sediment and surface water monitoring program. The same samples and monitoring will be taken at this site as at the monitoring sites in EFPC.

\subsubsection{Monitoring Schedule}

Surface water and redbreast sunfish samples will be collected biannually during the normal BMAP sampling program in winter and spring. Striped shiners and stonerollers will be sampled once each year, as scheduled by the Y-12 Plant BMAP. Surface water and sediment samples will be taken before remediation begins to form the preremediation baseline and will be taken twice yearly thereafter, roughly coincidentally with BMAP sampling. Existing BMAP data will also be used to form the preremediation baseline for surface water and fish. Because the 1995 surface water data will provide a preremediation baseline, no further baseline analysis of surface water will be required during spring of 1996.

\subsubsection{Sampling and Analytical Methods}

\subsubsection{Specifications for selection}

Sampling and analytical methods should be those used for BMAP sampling and analysis (Loar et al. 1992, Hinzman et al. 1993; QAP-X-90-ES-065, Rev. 1: Biological Monitoring and Abatement Program Quality Assurance Plan, Bioaccumulation Monitoring - Aquatic).

\subsubsection{Field sampling}

Field sampling of fish will follow relevant technical procedures described in QAP-X-90-ES-065, Rev. 1: Biological Monitoring and Abatement Program Quality Assurance Plan, Bioaccumulation Monitoring - Aquatic. Eight samples of redbreast sunfish will be collected at each site for the BMAP. On a one time basis, methyl mercury and total mercury in whole bodies of sunfish will be compared to the concentrations of mercury in sunfish filets so that the BMAP filet data can be used to evaluate ecological concerns. To evaluate filet vs. whole body concentrations in sunfish, three of the eight redbreast sunfish each site will be divided into two portions. One portion will consist of a small amount of fish muscle that will be weighed and analyzed to provide the filet concentration. The entire remaining portion will provide the whole body concentration (the filet data will be added back into the whole-body total).

Water samples for toxicity testing will be collected in accordance with technical procedures contained in QAP-X-89-ES-002, Oak Ridge National Laboratory Environmental Sciences Division Toxicology Laboratory Quality Assurance Program. Sediment samples will be collected in accordance with technical procedures contained in ES/ESH/INT-14: Environmental Surveillance Quality Control Program Manual.

Field samples of surface water samples for laboratory analysis of total mercury and methylmercury will be collected following EPA approved methods or guidance provided by Special 
Analytical Services. A portion of each sample will be filtered in the field through a $0.45 \mu \mathrm{m}$ pore-size filter, and both filtered and unfiltered samples will be analyzed.

\subsubsection{Laboratory analysis of total mercury and methylmercury}

Surface water, sediment, and fish samples will be analyzed for total mercury and methyl mercury. Samples will be sent to a qualified laboratory for analysis of total mercury and methylmercury. The required detection limits are $0.3 \mathrm{ng} / \mathrm{L}$ for total mercury and $0.03 \mathrm{ng} / \mathrm{L}$ (as mercury) for methylmercury in surface water and $0.1 \mu \mathrm{g} / \mathrm{kg}$ for total mercury and $0.05 \mu \mathrm{g} / \mathrm{kg}$ (as mercury) for methylmercury in soil, sediment, and tissue.

The total number of samples of surface water and sediment to be collected and analyzed during the first year, including QC samples, is summarized in Table 4.5. 
Table 4.5. Total mercury and methylmercury analyses for EFPC PMP surface water, sediment, soil, and terrestrial biota samples during 1996

\begin{tabular}{|c|c|c|c|c|}
\hline \multirow[t]{2}{*}{ Type of sample and analysis } & \multicolumn{2}{|c|}{ Spring 1996} & \multirow{2}{*}{$\begin{array}{c}\text { Fall } 1996 \\
\begin{array}{c}\text { Total } \\
\text { mercury }\end{array}\end{array}$} & \multirow[b]{2}{*}{$\begin{array}{l}\text { Methyl- } \\
\text { mercury }\end{array}$} \\
\hline & $\begin{array}{c}\text { Total } \\
\text { mercury }\end{array}$ & $\begin{array}{l}\text { Methyl- } \\
\text { mercury }\end{array}$ & & \\
\hline \multicolumn{5}{|l|}{ Surface water samples } \\
\hline EFPC sites & 0 & 0 & 12 & 12 \\
\hline Reference site & 0 & 0 & 2 & 2 \\
\hline Trip blank & $\mathbf{0}$ & 0 & 1 & 1 \\
\hline Field split sample & 0 & 0 & 2 & 2 \\
\hline \multicolumn{5}{|l|}{ Sediment samples } \\
\hline EFPC sites & 6 & 6 & 6 & 6 \\
\hline Reference sites & 1 & 1 & 1 & 1 \\
\hline Control sediment & 1 & 1 & 1 & 1 \\
\hline Trip blank (water only) & 1 & 1 & 1 & 1 \\
\hline Bottle blank (water only) & 1 & 1 & 0 & 0 \\
\hline Field split sample & 1 & 1 & 1 & 1 \\
\hline \multicolumn{5}{|l|}{ Fish samples } \\
\hline Redbreast sunfish & 40 & 15 & 40 & 0 \\
\hline Striped shiner & 15 & 15 & 0 & 0 \\
\hline Central stoneroller & 15 & 15 & 0 & $\mathbf{0}$ \\
\hline \multicolumn{5}{|l|}{ Soil samples } \\
\hline EFPC sites & 4 & 4 & 0 & 0 \\
\hline Reference site & 1 & 1 & 0 & 0 \\
\hline \multicolumn{5}{|l|}{ Earthworm samples } \\
\hline EFPC sites & 20 & 20 & 0 & 0 \\
\hline Reference site & 5 & 5 & 0 & $\mathbf{0}$ \\
\hline \multicolumn{5}{|l|}{ Starling samples } \\
\hline EFPC sites, eggs & 20 & 20 & 0 & 0 \\
\hline EFPC sites, nestlings & 20 & 20 & 0 & $\mathbf{0}$ \\
\hline Reference site, eggs & 5 & 5 & 0 & $\mathbf{0}$ \\
\hline Reference site, nestlings & 5 & 5 & $\mathbf{0}$ & 0 \\
\hline \multicolumn{5}{|l|}{ Total analyses } \\
\hline All samples & 161 & 136 & 67 & 27 \\
\hline
\end{tabular}




\subsubsection{Toxicity testing}

Sediment toxicity tests using Hyalella azteca will be carried out according to technical procedures described in QAP-X-89-ES-002, Oak Ridge National Laboratory Environmental Sciences Division Toxicology Laboratory Quality Assurance Program. Surface water toxicity tests using Ceriodaphnia dubia will be carried out according to technical procedures described in QAP-X-89-ES-002, Oak Ridge National Laboratory Environmental Sciences Division Toxicology Laboratory Quality Assurance Program.

\subsubsection{Decision Rules}

If sediment downstream of a remediated site is more toxic ( $90 \%$ confidence level) than sediment upstream of the site for two successive years and UCL mercury concentrations are higher downstream of site than upstream of site, conclude that residual concentrations in the remediated soil are causing adverse impacts to benthic biota. If sediment toxicity at all sites is consistently correlated $(p<0.1)$ with sediment total mercury or methylmercury concentrations, including baseline and postremediation, and with mercury concentrations in soil at associated sites, conclude that residual mercury concentrations in soil at sites upstream of demonstrated toxicity are causing adverse impacts to benthic biota. If uncorrelated for two successive years, conclude that residual mercury in soil does not cause adverse impact to benthic biota and that monitoring of sediment toxicity may be discontinued.

If EFPC surface water is more toxic ( $90 \%$ confidence level) to Ceriodaphnia than surface water from a reference site and relative to laboratory control water, conclude that adverse effects to aquatic biota are possible. If concentrations of methylmercury in fish are $>0.1 \mathrm{mg} / \mathrm{kg}$, conclude that adverse impacts to piscivorous birds is possible (DOE 1995c). If concentrations of total mercury or methylmercury in surface water exceed limits specified by the NPDES permit, conclude that adverse impacts to aquatic biota are possible. Scientific judgement of the investigators and regulators will be required to determine whether there are adverse impacts to aquatic biota that are caused by mercury species in soil-derived sediment.

\subsection{MONITORING WETLANDS RESTORATION}

Monitoring for wetlands restoration as described in this section will provide information to allow investigators to determine whether constructed wetlands develop the requisite characteristics that define a wetland.

A small portion of wetland COE ID No. 8 [0.24 ha (0.6 acres)] will be excavated at the Bruner site. A wetland will be reconstructed at the same location.

\subsubsection{Monitoring Rationale}

The goal of wetland restoration or reconstruction is that there is no net loss of wetland function after excavation of contaminated wetlands. Monitoring of constructed wetlands is essential to ensure that natural wetland function has developed. The mitigation plan describes (1) the size and location of the area to be excavated, (2) the specific type and size of wetland habitat(s) to be created or restored, (3) the hydrologic regime including the hydroperiod and water depth desired for each habitat type, and (4) the wetland functions to be restored or replaced. 


\subsubsection{Monitoring goals}

The goal of wetland restoration or construction is to create or recreate the three conditions that meet the regulatory definition of a wetland (Environmental Laboratory 1987), i.e., establishing hydrophytic vegetation, hydric soils, and wetland hydrology. The goal of monitoring restored or constructed wetlands is to provide the necessary data to evaluate the effectiveness of wetland restoration or construction. The objective of the PMP for wetland monitoring is to evaluate the development of wetland characteristics in the restored or constructed wetlands.

\subsubsection{Monitoring endpoints}

The monitoring endpoints for wetlands restoration are: the presence of hydrophytic vegetation, presence of water-saturated soil for a significant portion of the growing season (to represent hydric soils), and presence of enough water to saturate or inundate the site for the minimum critical period to establish wetland hydrology, as specified in the mitigation plan (at a minimum 10 to $14 \mathrm{~d}$ of continuous saturation or inundation). Measurement endpoints for wetlands are:

- Measurement endpoint 9: the abundance, frequency, and distribution of facultative wetland (FACW) and obligate wetland (OBL) plant species in the restored or constructed wetland.

- Measurement endpoint 10: the duration of soil saturation or inundation at the site during the local growing season.

\subsubsection{Monitoring Endpoint Entities}

Wetland function depends upon the success of establishing three wetland criteria: (1) hydrophytic vegetation, (2) hydric soils, and (3) wetland hydrology (Environmental Laboratory 1987). Hydrophytic vegetation is characterized by the predominance $(>50 \%)$ of facultative (FAC), FACW, and OBL species for the region. Reed (1988) contains information about indicator species. Because facultative plants live in nonwetlands as easily as in wetlands, the success of establishing wetland vegetation in restored or constructed wetlands should be based on FACW and OBL species only. Characteristics of hydric soils and wetland hydrology do not depend on populations for which there are representative species, but rather on the presence of water in the soil (Environmental Laboratory 1987). The success of establishing hydric soils and wetland hydrology should be measured by documenting sufficient saturation or inundation of the affected area for the minimum critical period specified in the mitigation plan (preferably a minimum of 10 to 14 consecutive days of saturation or inundation during the local growing season).

\subsubsection{Monitoring Locations}

Inspection will encompass the area delineated by the wetland reconstruction team and described in the wetlands mitigation plan.

\subsubsection{Monitoring Schedule}

Inspection of the reconstructed wetland will be done annually, in mid to late summer when vegetation production is maximal. Monitoring will continue for five years, at which time an evaluation will be prepared as part of the five-year monitoring report. 


\subsubsection{Wetland Evaluation Methods}

Methods for evaluation of reconstructed wetlands will be those described in the Corps of Engineers Wetlands Delineation Manual (Environmental Laboratory 1987), recognizing however that the colors characteristic of hydric soils develop slowly and will not be included in the evaluation of reconstructed wetlands. Periodic surveys will document the abundance and distribution of FACW and OBL plants at the site, as well as saturation or inundation of soil at the site.

Photographs of the site will be taken to document existing site conditions at the time of inspection. At least some of the photographs will be taken from fixed locations to document changes that occur over time. Annual inspections will determine whether the reconstructed wetland area is at least as large as the original reconstructed wetland area.

\subsubsection{Decision Rules}

If the requisite properties of wetlands are observed in the area specified by the mitigation plan by the wetlands assessor, conclude that the wetland has been mitigated.

\subsection{MONITORING GROUNDWATER USE}

Monitoring for groundwater use will identify potential new groundwater wells in the shallow water table of the EFPC floodplain and allow for mitigation of their use as drinking water.

\subsubsection{Monitoring Rationale}

The risk assessment for the EFPC floodplain indicated a potential risk from ingestion of drinking water from the shallow groundwater table. Risks were attributed to manganese and arsenic, but there is uncertainty as to whether manganese and arsenic concentrations are elevated above background concentrations. Regardless, there is currently no use in the EFPC floodplain of groundwater as a drinking water source, and it is unlikely that the shallow groundwater aquifer will be used in the future. Therefore, no remediation of groundwater was specified in the record of decision (ROD). However, the ROD specified that the use of the shallow groundwater aquifer as a drinking water source will be monitored, and if such use is discovered, DOE will mitigate as appropriate (DOE 1995b).

\subsubsection{Monitoring goals}

The goal of monitoring for consumption of shallow groundwater is to provide the necessary information to allow DOE to prevent harm to humans through exposure to contaminants in shallow groundwater.

\subsubsection{Monitoring endpoints}

The monitoring endpoint for consumption of shallow groundwater from the Lower EFPC floodplain is the presence of a well or wells in the floodplain.

\subsubsection{Monitoring Endpoint Entities}

The monitoring endpoint entities for groundwater consumption are shallow groundwater wells in the Lower EFPC floodplain. 


\subsubsection{Monitoring Locations}

Privately owned parcels that contain a portion of the EFPC floodplain and a residence will be subject to the annual well surveillance. Because of hazards associated with the land use, the Sportsman's Association property will not be traversed during this surveillance.

\subsubsection{Monitoring Schedule}

Monitoring will be done annually during the summer months. Scheduling of the surveillance will be done each year, with the day to be chosen by the monitoring contractor to avoid danger from high water in the creek after a storm or other adverse circumstances. The need to monitor groundwater use will be reevaluated as part of the five-year review.

\subsubsection{Monitoring Methods}

Because annual surveys of all landowners with property in the EFPC floodplain or access agreements to inspect all EFPC floodplain properties would be prohibitively expensive, an annual surveillance of the floodplain will be carried out by visual inspection. Where the entire floodplain is visible from a public roadway, the inspection can by done by foot or motor vehicle. Where the floodplain cannot be seen from a public roadway, the inspection will be done by entering the creek from a publicly accessible location and walking in the creek bed. It is assumed that evidence of potential well installation, such as a well house, will be obvious upon visual inspection.

\subsubsection{Decision Rules}

If it is concluded that a well might have been installed, that information will be given to DOE. DOE will contact the landowner to determine whether groundwater use is occurring and, if so, what mitigative measures to take.

\subsection{SUMMARY OF DECISION RULES}

Decision rules have been specified above for each medium that will be monitored. In this section, the decisions to be made, decision rules (see Chap. 2.3.5), and the data required [along with the required statistical limits of uncertainty (see Chap. 2.3.6)] for the decisions are summarized in Table 4.6. Because ecological effects are very complex, it is important that these decision rules are treated as guidelines; scientific judgement of investigators, DOE, and the regulators should supersede the rules if necessary. 
Table 4.6. Decision rules and data required for decisions

\begin{tabular}{|c|c|c|}
\hline Question & Decision rule & Data required \\
\hline $\begin{array}{l}\text { Does remediation } \\
\text { mobilize soil mercury? }\end{array}$ & $\begin{array}{l}\text { If postremediation UCL body burdens are } \\
\text { consistently above baseline UCL body burden } \\
\text { at remediated sites, conchude yes. If } \\
\text { postremediation body burdens are at or below } \\
\text { baseline level for two successive years, } \\
\text { conchude no and monitoring may be } \\
\text { discontinued until year five. }\end{array}$ & $\begin{array}{l}\text { Mean, 95th percentile UCL of the } \\
\text { mean, and maximum total mercury } \\
\text { and methylmercury content of } \\
\text { earthworms and starlings, baseline } \\
\text { and postremediation, at four } \\
\text { floodplain sites and one reference } \\
\text { site. }\end{array}$ \\
\hline & $\begin{array}{l}\text { If postremediation UCL mercury } \\
\text { concentrations in sediment are higher than } \\
\text { baseline UCL concentrations, conchude yes. If } \\
\text { postremediation sediment mercury } \\
\text { concentrations are at or below baseline level }\end{array}$ & $\begin{array}{l}\text { Mean, } 95 \text { th percentile UCL of the } \\
\text { mean, and maximum total mercury } \\
\text { and methylmercury content of } \\
\text { sediment upstream and downstream } \\
\text { of two remediation sites. }\end{array}$ \\
\hline
\end{tabular}

Are residual mercury concentrations in soil harmful to terrestrial biota?

Are residual mercury concentrations in remediated soil harmful to benthic biota?

Are residual mercury concentrations in soilderived sediment harmful to benthic biota? for two successive years, conclude no and monitoring may be discontinued until year five.

If LCL reproductive success of starlings (fraction of eggs hatched and fraction of young fledged) is consistently lower at all test sites than at the reference site and UCL reproductive success is consistently higher at the remediated sites postremediation than at baseline, conclude yes. If not so for two successive years, conclude no and monitoring may be discontinued until year five.

If upper UCL body burden of methyl- mercury in starlings is above $2.5 \mathrm{mg} / \mathrm{kg}^{\circ}$ for two years, conclude yes for that site.

If sediment downstream of remediated site is consistently more toxic than sediment upstream of remediated site for two successive years and UCL mercury concentrations are higher downstream of site than upstream of site, conchude yes.

If sediment toxicity at all sites is consistently correlated with sediment total mercury or methylmercury concentrations $(p<0.1)$, including baseline and postremediation, conchude yes. If uncorrelated for two successive years, conchude no and monitoring may be discontinued.
Mean, 95th percentile LCL of the mean, and minimum reproductive success of starlings, baseline and postremediation, at all sites.

Mean, 95th percentile UCL of the mean, and maximum methylmercury concentrations in starlings, baseline and postremediation, at all sites.

Whole-sediment toxicity data, baseline and postremediation, upstream and downstream of remediated sites; mean, 95th percentile UCL of the mean, and maximum of sediment concentrations of total mercury and methylmercury.

Mean concentrations of mercury species in sediment and nonparametric ranking of wholesediment toxicity; both sets of data for baseline and postremediation samples at all sites. 
Table 4.6 (continued)

\begin{tabular}{|c|c|c|}
\hline Question & Decision rule & Data required \\
\hline $\begin{array}{l}\text { Are residual mercury } \\
\text { concentrations in soil- } \\
\text { derived sediment } \\
\text { harmful to aquatic } \\
\text { biota? }\end{array}$ & $\begin{array}{l}\text { Computations using dietary toxicity } \\
\text { benchmarks and scientific judgement of the } \\
\text { investigators and regulators will be required to } \\
\text { determine whether there are adverse impacts to } \\
\text { aquatic biota that are caused by mercury } \\
\text { species in soil-derived sediment. }\end{array}$ & $\begin{array}{l}\text { Results of BMAP measurements of } \\
\text { mercury species in surface water } \\
\text { and ambient toxicity testing. }\end{array}$ \\
\hline $\begin{array}{l}\text { Are residual mercury } \\
\text { concentrations in soil- } \\
\text { derived sediment } \\
\text { harmful to predators of } \\
\text { aquatic biota? }\end{array}$ & $\begin{array}{l}\text { Computations using dietary toxicity } \\
\text { benchmarks and scientific judgement of the } \\
\text { investigators and regulators will be required to } \\
\text { determine whether there are potential adverse } \\
\text { impacts to piscivorous predators that are } \\
\text { caused by mercury species in soil-derived } \\
\text { sediment. }\end{array}$ & $\begin{array}{l}\text { Whole-body concentrations of total } \\
\text { mercury and methylmercury in fish. }\end{array}$ \\
\hline $\begin{array}{l}\text { Has wetland mitigation } \\
\text { restored wetland } \\
\text { characteristics to the } \\
\text { mitigated area? }\end{array}$ & $\begin{array}{l}\text { If wetland characteristics are observed by the } \\
\text { wetland assessor throughout the area specified } \\
\text { by the mitigation plan, conclude yes. }\end{array}$ & Results of wetlands inspections. \\
\hline $\begin{array}{l}\text { Is shallow groundwater } \\
\text { being used for drinking } \\
\text { water? }\end{array}$ & $\begin{array}{l}\text { If no wells are observed in the floodplain by } \\
\text { annual surveillance, conclude no. }\end{array}$ & Annual surveillance of floodplain. \\
\hline
\end{tabular}




\section{DATA REPORTING AND USE}

\section{S.1 REPORTING SCHEDULE AND FORMAT}

Data and information, their evaluation, and conclusions should be made available at regular intervals so the appropriate managers and regulators can track the protectiveness and effectiveness of the remedial plan. Two appropriate report formats are discussed in the following subsections. Both detailed reports to the regulatory agencies and annual surveillance reports are appropriate means of communicating results.

\subsubsection{Reports to EPATDEC}

An annual report should be submitted to DOE, EPA, TDEC, and Lockheed Martin Energy Systems, Inc. (Energy Systems). This reports should include the results of monitoring, describe trends, and interpret them in terms of remedial goals.

\subsubsection{ORR Annual Surveillance Report}

The Oak Ridge Reservation (ORR) Annual Surveillance Report presents observations about many facets of environmental monitoring on the ORR. Each annual report typically includes data obtained by the various Biological Monitoring and Abatement Programs (BMAP), as well as water quality information and concentrations of contaminants in groundwater, surface water, and air. In this format, data are published quickly and regularly but data are generally presented with less interpretation than is found in technical monographs. It is appropriate that Energy Systems, at its discretion, report results of the Post Remediation Monitoring Program (PMP) in the ORR Annual Surveillance Report.

\subsection{REVIEW AND DECISION PROCESS}

The following subsections establish a process for review of the monitoring results and revision of the monitoring plan as needed to meet the requirements of the ROD.

\subsubsection{Five-year Review of EFPC Monitoring}

The ROD states that no contaminants will remain in the EFPC floodplain at levels that will prevent unrestricted use. However, there is uncertainty about the protectiveness of the planned remediation for ecological receptors. Therefore, a five-year review of monitoring results in accordance with CERCLA statutory requirements is appropriate.

\subsubsection{Evaluation of Monitoring Endpoints}

Monitoring endpoints for the EFPC PMP are evaluated using the ten measurement endpoints. The data from EFPC and reference locations are used to evaluate whether the remedial plan is protective of the environment over the duration of the PMP.

The monitoring endpoint for EFPC soil and associated organisms is evaluated using data collected for Measurement endpoints 1,2,3, and 4. The tissue-mercury concentrations from Monitoring endpoints 1 and 2 are used to evaluate whether the exposure of monitoring endpoint 
organisms to mercury in the environment has increased. The population data from endpoint 3 and toxicity data from endpoint 4 , if required, are used to evaluate if there has been an increase in adverse effects on those receptors. Data from the reference site are used to evaluate whether increases in exposure, adverse effects, or both at EFPC monitoring locations are due to local or regional processes influencing the availability of mercury in soil and the survival and reproduction of monitoring endpoint organisms.

The monitoring endpoint for EFPC sediment, surface water, and associated organisms is evaluated using data collected for Measurement endpoints 5,6,7, and 8 . The toxicity test data from endpoints 6 and 7 are used to evaluate if there has been an increase in adverse effects on monitoring endpoint organisms. The mercury concentration data from Measurement endpoint 8 are used to evaluate whether the exposure of monitoring endpoint organisms to mercury in the environment has increased. Data from the reference site are used to evaluate whether increases in exposure, adverse effects, or both at EFPC monitoring locations are due to local or regional processes. These processes influence the availability of mercury in sediment or surface water and the survival and reproduction of monitoring endpoint organisms. Data from monitoring locations upstream and downstream of terrestrial soil-remediation sites are compared to evaluate whether soil excavation has an adverse impact on aquatic monitoring endpoint organisms in EFPC.

If the evaluation of monitoring data indicates that there has been an increase in the exposure of and effects on monitoring endpoint organisms due to mercury in the EFPC environment, then the risk to ecological receptors would need to be evaluated in accordance with the EFPC Baseline Ecological Risk Assesment (BERA) assessment endpoints. The exposure and level of adverse effects on endpoint organisms observed in the EFPC PMP are used to estimate the exposure and level of adverse effects on BERA endpoint entities [mid-level predators (e.g., wrens and shrews) and top predators (mink, heron, kingfisher)]. The level of adverse effects estimated from the predicted or measured exposure of ecological receptors to mercury are then compared to the level of protection specified in the BERA assessment endpoints, and a decision is made as to whether the remedial plan for Lower EFPC is protective or needs to be revised.

A comparison of monitoring results to assessment endpoints may show that some endpoints are being met, whereas others are not. If it is clear that an assessment endpoint is being met and there is no trend suggesting that it may not be met in the future, the intensity of monitoring for that endpoint could be reduced. Instead, a greater number of samples could be taken to clarify that another endpoint is not being met or to fill data gaps identified by evaluation of the results.

\subsubsection{Modification of Monitoring Plan}

If review of the monitoring data reveals data gaps not foreseen in this plan, the plan should be revised to collect the necessary additional data. Modification of the monitoring plan should be done in consultation with DOE, EPA, and TDEC. 


\section{SUPPORTING DOCUMENTS}

\subsection{QUALITY ASSURANCE PROJECT PLAN}

Sampling and analysis of soil, sediment, surface water, and biota will be carried out according to requirements of the BMAP quality assurance (QA) plan. The BMAP and Lower EFPC Remedial Design QA plans meet the requirements of DOE Order 5700.6C and of the Environmental Restoration Division Quality Assurance Program Plan, ES/ER/TM-4/R4. These documents have similar, specific elements required for a QA project plan to ensure the highest quality, accountability, and traceability of data in sampling, analysis, and reporting activities.

The QA plan for the BMAP, QAP-X-90-ES-063, Rev. 1: Environmental Sciences Division, Biological Monitoring and Abatement Program Quality Assurance Program Plan, was revised based on DOE Order 5700.6C. The correspondence of BMAP QA procedures with requirements of DOE Order $5700.6 \mathrm{C}$ is as follows:

\begin{tabular}{lc} 
5700.6C Criteria & BMAP QA procedure number \\
\cline { 2 - 2 } Program & QAP-1 \\
Training and Qualification & QAP-2 \\
Quality Improvement & QAP-3 \\
Documents and Records & QAP-4 \\
Work Processes & QAP-5 \\
Design & QAP-6 \\
Procurement & QAP-7 \\
Inspection and Acceptance Testing & QAP-8 \\
Management Assessment & QAP-9 \\
Independent Assessment & QAP-10
\end{tabular}

These procedures are contained within the BMAP QA Plan.

\subsubsection{Sample Collection Procedures}

Samples must be collected according to standardized procedures to ensure their quality and integrity. These procedures are referenced or detailed in the BMAP QA plan and include the following procedures:

QAP-X-90-ES-063, Rev. 1: Environmental Sciences Division, Biological Monitoring and Abatement Program Quality Assurance Program Plan

QAP-X-89-ES-002, Oak Ridge National Laboratory Environmental Sciences Division Toxicology Laboratory Quality Assurance Program

QAP-X-90-ES-065, Rev. 1: Biological Monitoring and Abatement Program Quality Assurance Plan, Bioaccumulation Monitoring - Aquatic

ES/ESH/INT-14, Environmental Surveillance Quality Control Program Manual

ESQAP-95-0720, Rev. 0: Biological Monitoring and Abatement Program Quality Assurance Plan, Soil Toxicity Testing 
ESQAP-96-0201, Rev. 0: Biological Monitoring and Abatement Program Quality Assurance Plan, Bioaccumulation Monitoring - Terrestrial

Also included are requirements for duplicates and field blanks as well as decontamination procedures used to ensure that there is no cross-contamination between samples.

\subsubsection{Sample, Document, and Custody Procedures}

Samples will be documented to trace the movement of samples from the field through analysis and reporting. The forms and requirements for the field and site logbooks as well as all of the information for labeling of samples are detailed in the BMAP QA plan. The sample identification system and the definition of custody of those samples as well as the responsibilities associated with reporting and documenting custody of samples are included.

\subsubsection{Analytical Methods}

Because low concentrations of methylmercury are possible in all samples and low concentrations of total mercury are expected in surface water, standard analytical methods are not sufficiently sensitive for the requirements of this study. Special analytical services will be required, e.g., ethylation of total mercury followed by gas chromatography and detection by atomic fluorescence is recommended for methylmercury analyses. Detection limits of this method are 0.1 $\mu \mathrm{g} / \mathrm{kg}$ for total mercury and $0.05 \mu \mathrm{g} / \mathrm{kg}$ (as mercury) for methylmercury.

\subsubsection{Quality Control Sample Checks}

Quality control (QC) sample checks are used to (1) monitor sample collection and sample handling techniques, (2) evaluate equipment and contained decontamination procedures, (3) assess the sensitivity of test organisms and the credibility of the test system, (4) measure the precision of analytical methods, and (5) document equipment calibration. These checks may include, but are not limited to, field blanks, trip blanks, laboratory splits, duplicates, replicates, controls, equipment rinse blanks, matrix spikes, and certified standards for instrument calibration. Requirements for QC sample checks are included in the BMAP QA plan and the Lower EFPC Remedial Design QA plan.

\subsubsection{Project Data Quality Assessment}

The requirements for the final data record for each sample include information such as unique sample code, sampling location and date, laboratory analysis identification number, analyses performed, detection limits, reporting units, and analysis qualifiers. Additionally, analytical instruments need to meet precision and calibration requirements necessary to meet project data quality standards.

\subsubsection{Data Reduction and Reporting}

U.S. EPA Contract Laboratory Program Statement of Work and the Test Methods for Evaluating Solid Wastes (EPA 1986) give guidelines as to the reduction of data. Computerized programs to reduce and analyze data should be under software QC according to ES/ER/TM-4/R4 as referenced in Chap. 6.1 above. An independent analyst needs to review an appropriate level of validation/verification of the data, which need to be reported on standardized forms for the manual and electronic transfer from the laboratory to the data generator. The data will be validated according to standard EPA procedures. 


\subsubsection{Audits and Surveillances}

Audits and surveillance of field and laboratory activities will be scheduled, planned, performed, and documented. A performance audit or surveillance evaluates the effectiveness of the project in fulfilling its objectives and determines whether those activities comply with procedures and other applicable documents.

An audit is a planned and documented activity performed to determine through investigation, examination, or evaluation of objective evidence: (1) the adequacy of and compliance with established procedures, instructions, drawings, and other applicable documents, and (2) the effectiveness of implementation. Audits will be performed by personnel independent of (and external to) the organization or entity being evaluated.

Surveillance is the act of monitoring or observing that requirements have been specified and that items or activities conform to those specified requirements. A surveillance is an internal evaluation conducted and performed regularly by management personnel or their representatives to assess the adequacy and effectiveness of that part of the QA program for which they are responsible.

\subsubsection{Corrective Action Plan}

Conditions adverse to quality, which may adversely affect personnel or public safety and health, the environment, or the reliability of the monitoring activities and/or data must be promptly identified and corrected by authorized personnel. The root cause of these significant conditions must also be properly documented and promptly reported to management.

Conditions adverse to quality are defined as conditions that exceed predetermined acceptability limits, deviate from prescribed methods, fail to meet performance requirements or data quality objectives, or fail to meet regulatory requirements. The BMAP QA Plan and the Lower EFPC Remedial Design QA Plan specify procedures to follow upon identification of a nonconformance or adverse condition including description of the problem, determination of the corrective action, and notification of the proper authorities.

\subsection{HEALTH AND SAFETY PLAN}

The health and safety plan is designed to provide guidance to protect the personnel involved in the PMP. DOE is committed to limiting chemical and radiation exposures to levels that are as low as reasonably achievable (ALARA) as well as limiting physical hazards in the workplace. The ALARA policy applies to all sampling and monitoring activities. The health and safety plan will consist of the Environmental Restoration Program Technical Support Contractor Master Health and Safety Plan, DOE/OR-925, the Site Safety and Health Plan for Lower EFPC (to be included in the $60 \%$ Design Package), and the Oak Ridge National Laboratory Environmental Sciences Division (ESD) Health and Safety Checklist, which incorporate the appropriate DOE orders, and in compliance with requirements mandated by the Occupational Safety and Health Administration in accordance with the regulations 29 CFR 1910.120.

The ESD Health and Safety Checklist defines the program and project personnel and their respective roles in the PMP. Included in these role descriptions are all of the requirements for maintenance of health and safety within ORR programmatic guidelines. Risks to personnel from site contaminants and physical hazards associated with sampling are identified and assessed, and 
mitigative measures such as proper training, safety procedures, and appropriate personal protective equipment are described.

The Site Safety and Health Plan describes the measures necessary to establish exclusion zones around contaminated areas for the protection of workers and visitors to the sampling sites. It describes proper decontamination procedures for both personnel and equipment. It sets forth the general safety rules in the site operating procedures. The Site Safety and Health Plan also includes a contingency plan to describe responses to potential emergencies such as fires, chemical spills, or personnel injury, and defines the procedures for reporting any such incidences.

\subsection{WASTE MANAGEMENT PLAN}

The objectives of a waste management plan are to identify analytical requirements, personnel responsibilities and types, anticipated characterizations, and volumes of wastes that will be generated by sampling and monitoring activities conducted as outlined in this ecological monitoring plan. The waste management plan also establishes treatment, storage, and disposal objectives for projectderived wastes prior to final remedial activities.

Waste management for the PMP will follow the requirements of Waste Management Plan for the Lower East Fork Poplar Creek Remedial Action Project, which is based on the InvestigationDerived Waste (IDW) Policy on the ORR (as stated in the Guide to Management of InvestigationDerived Wastes, EPA publication 9345.3-03FS, January 1992; and the draft Central Environmental Restoration Program procedure, Management of Investigation-Derived Waste, Martin Marietta Energy Systems, Inc., December 1991) and requirements of QAP-X-90-ES-063, Rev. 1:

Environmental Sciences Division, Biological Monitoring and Abatement Program Quality Assurance Program Plan. A project-specific health and safety checklist will be prepared before sampling begins.

Indigenous IDW expected from the monitoring plan comprise residual soil, sediment, and biota samples not consumed during analysis. These wastes may be returned to ESD for disposal in a sanitary landfill or hazardous waste landfill, as provided by the Waste Management Plan and the project-specific health and safety checklist. Nonindigenous investigation-derived waste (IDW) will include disposable personal protective equipment and decontamination fluids. Disposable equipment and decontamination fluids will be collected and disposed of in accordance with the health and safety checklist. According to policy, the quantity of wastes generated will be minimized to the extent practicable with considerations for the protection of the public, workers, and the environment. Past sampling data can be used to characterize wastes as nonhazardous until the wastes can be characterized on the basis of analytical data received from the PMP. Wastes will be stored and labeled according to existing IDW policy requirements. 


\section{REFERENCES}

Barnes, R.D. 1974. Invertebrate Zoology. W.B. Saunders Company, Philadelphia.

Bechtel. 1994. Field Work Guide for WAG 5 Earthworm Sampling. Bechtel National, Inc. Oak Ridge, Tennessee. Document No. 19118-05-WG-21.

Borror, D.J., and D.M. DeLong. 1964. An Introduction to the Study of Insects (revised edition). Holt, Rinehart, and Winston, New York.

Carmichael, J.K. 1989. An Investigation of Shallow Groundwater Quality Near East Fork Poplar Creek, Oak Ridge, Tennessee, Water-Resources Investigation Report 88-4219, U.S. Geological Survey.

COE (U.S. Army Corps of Engineers). 1992. An Inventory of Wetlands in the East Fork Poplar Creek Floodplain in Anderson and Roane Counties, Tennessee. Preliminary Draft Report to the U.S. Department of Energy. $21 \mathrm{pp}$. plus appendices.

DOE (U.S. Department of Energy). 1992. Federal Facility Agreement for the Oak Ridge Reservation. DOE/OR-1014. U.S. Environmental Protection Agency Region IV, Atlanta, GA, U.S. Department of Energy, Oak Ridge Operations, Oak Ridge, Tennessee, and Tennessee Department of Environment and Conservation, Nashville, Tennessee. January.

DOE. 1994a. East Fork Poplar Creek - Sewer Line Beltway Remedial Investigation Report, DOE/OR/02-1119\&D2. Prepared for U.S. DOE by Science Applications International Corporation (SAIC), Oak Ridge, Tenn.

DOE. 1994b. Addendum to the East Fork Poplar Creek - Sewer Line Beltway Remedial Investigation Report. DOE/OR/02-1119\&D2/A1/R1. Prepared for U.S. DOE by Science Applications International Corporation (SAIC), Oak Ridge, Tenn.

DOE. 1994c. Feasibility Study for the East Fork Poplar Creek - Sewer Line Beltway. DOE/OR/02-1185\&D2. Prepared for U.S. DOE by Science Applications International Corporation (SAIC), Oak Ridge, Tenn.

DOE. 1995a. Proposed Plan, East Fork Poplar Creek - Sewer Line Beltway, Oak Ridge, Tennessee. DOE/OR/02-1209\&D3. Prepared for U.S. DOE by Jacobs Engineering, Oak Ridge, Tenn.

DOE. 1995b. Record of Decision for Lower East Fork Poplar Creek. DOE/OR/02-1370\&D1. Prepared for U.S. DOE by Jacobs Engineering, Oak Ridge, Tenn.

DOE. 1995c. Remedial Goal Options for Mercury in Sediment of East Fork Poplar Creek, Oak Ridge, Tennessee. DOE/OR/01-1342\&D2. Prepared for U.S. DOE by Science Applications International Corporation (SAIC), Oak Ridge, Tenn.

DOE. 1995d. Revised Remedial Goal Options for Mercury in Soil of East Fork Poplar Creek, 
Oak Ridge, Tennessee. Report prepared for DOE by SAIC, Oak Ridge, Tennessee. April.

Eisler, R. 1987. Mercury Hazards to Fish, Wildlife, and Invertebrates: A Synoptic Review. Biological Report 85(1.10), Fish and Wildlife Service, U.S. Department of the Interior, Patuxent, MD.

Environmental Laboratory. 1987. Army Corps of Engineers Wetlands Delineation Manual, Technical Report Y-87-1, U.S. Army Engineers Waterways Experiment Station, Vicksburg, Miss. $100 \mathrm{pp}$.

EPA (U.S. Environmental Protection Agency). 1985a. Environmental Profiles and Hazard Indices of Constituents of Municipal Sludge: Mercury. Office of Water Regulations and Standards, U.S. EPA, Washington, DC.

EPA. 1985b. Ambient Water Quality Criteria for Mercury - 1984. EPA440/5-84/026. Office of Water. Washington, DC.

EPA. 1986. Test Methods for Evaluating Solid Waste. SW/846.

EPA. 1988. Guidance for Conducting Remedial Investigations and Feasibility Studies Under CERCLA, Interim Final. EPA/540/G-89/004. OSWER Directive 9355.3-01. Office of Emergency and Remedial Response.

EPA. 1992a. Sediment Classification Methods Compendium. EPA/823/R-92/006. Office of Water. Washington, DC.

EPA. 1992b. Framework for Ecological Risk Assessment. Washington, DC.

Etnier, D. A. and W. C. Starnes. 1993. The Fishes of Tennessee. University of Tennessee Press. Knoxville. $681 \mathrm{pp}$.

Gunn, A. 1992. "The Use of Mustard to Estimate Earthworm Populations," Pedobiologia 36:65-67.

Hildebrand, S., J. Huckabee, F. Diaz, S. Janzen, J. Solomon, and K. Kumar. 1980. Distribution of Mercury in the Environment at Almaden, Spain. ORNL/TM-7446. Environmental Sciences Division, Oak Ridge National Laboratory, Oak Ridge, Tenn.

Hinzman et al. 1993. Second Report on the Oak Ridge Y-12 Plant Biological Monitoring and Abatement Program for East Fork Poplar Creek. Y/TS-888. Environmental Sciences Division, Oak Ridge National Laboratory, Oak Ridge, Tenn.

Hinzman et al. 1995. Oak Ridge Y-12 Plant Biological Monitoring and Abatement Program Plan. ORNL/TM-13145. Environmental Sciences Division, Oak Ridge National Laboratory, Oak Ridge, Tenn. 
Kendall, R.J., L. W. Brewer. T. E. Lacher, Jr., B.T. Marden and M.L. Whitten. 1989. The Use of Starling Nest Boxes for Field Reproductive Studies. Provisional Guidance Document and Technical Support Document, EPA/600/8-89/056. U.S. Environmental Protection Agency, Washington, DC.

Loar et al. 1989. The Oak Ridge Y-12 Plant Biological Monitoring and Abatement Program for East Fork Poplar Creek. ORNL/TM-10265. Environmental Sciences Division, Oak Ridge National Laboratory, Oak Ridge, Tenn.

Loar et al. 1992. First Report on the Oak Ridge Y-12 Plant Biological Monitoring and Abatement Program for East Fork Poplar Creek. Y/TS-886. Environmental Sciences Division, Oak Ridge National Laboratory, Oak Ridge, Tenn.

Moneymaker, R.H. 1981. Soil Survey of Anderson County, Tennessee. USDA Soil Conservation Service, Washington, DC.

Norris, M.J. 1993. Mercury Abatement at the Oak Ridge Y-12 Plant: A Progress Report. Y/ER-116.

Odin, M., A. Feurtet-Mazel, F. Ribeyre, and A. Boudou. 1994. "Actions and Interactions of Temperature, pH, and Photoperiod on Mercury Bioaccumulation by Nymphs of the Burrowing Mayfly Hexagenia rigida, from the Sediment Contamination Source." Environ. Toxicol. Chem. 13: 1291-1302.

Opresko, D.M., B.E. Sample, and G.W. Suter II. 1994. Toxicological Benchmarks for Wildlife: 1994 Revision. ES/ER/TM-86/R1. Environmental Sciences Division, Oak Ridge National Laboratory, Oak Ridge, Tenn.

Phillips, G.R., and D.R. Buhler. 1978. "The Relative Contributions of Methylmercury from Food or Water to Rainbow Trout (Salmo gairdneri) in a Controlled Laboratory Environment'". Transactions of the American Fisheries Society 107: 853-861.

Reed, P.B., Jr. 1988. National List of Plants That Occur in Wetlands: National Summary. U.S. Fish and Wildlife Service Biological Report 88(24). 224 pp.

Revis, N., G. Holdsworth, G. Bingham, A. King, and J. Elmore. 1989. An Assessment of Health Risk Associated with Mercury in Soil and Sediment from East Fork Poplar Creek, Oak Ridge, Tennessee. Oak Ridge Research Institute. Final report. pp. 1-58.

SAIC (Science Applications International Corporation). 1994. Special Field Investigation for Sediment Chronic Toxicity in East Fork Poplar Creek. Prepared for U.S. Department of Energy under contract DE-AC05-91OR21950, Oak Ridge, Tennessee.

SCS (Soil Conservation Service). 1991. Hydric Soils of the United States. Third Edition. USDA-SCS Miscellaneous Publication 1491. 
Suter, G.W. II, and J.B. Mabrey. 1994. Toxicological Benchmarks for Screening Potential Contaminants of Concern for Effects on Aquatic Biota: 1994 Revision. Environmental Sciences Division, Oak Ridge National Laboratory, Oak Ridge, Tenn.

Talmage, S.A., and B. Walton. 1993. "Food Chain Transfer and Potential Renal Toxicity of Mercury to Small Mammals at a Contaminated Terrestrial Field Site." Ecotoxicology 2: 243-256.

TVA (Tennessee Valley Authority). 1985. Instream Contaminant Study, Task 1: Water Sampling and Analysis, Task 2: Sediment Characterization, Task 3: Sediment Transport, Task 4: Fish Sampling and Analysis, Task 5: Summary Report. Prepared for U.S. Department of Energy, Oak Ridge, Tennessee, under Interagency Agreement No. DE-AI0584OR21444, January.

Van Winkle, W., R.W. Counts, J.G. Dorsey, J.W. Elwood, V.W. Lowe, Jr., R. McElhaney, S.D. Schlotzhauer, F.G. Taylor, Jr., and R.R. Turner. 1984. Mercury Contamination in East Fork Poplar Creek and Bear Creek. ORNL/TM-8894. Oak Ridge National Laboratory, Oak Ridge, Tenn. 


\section{DISTRIBUTION}

1. L. V. Asplund

2. B. W. Henderson

3-4. A. K. Lee/DOE-OSTI

5-7. D. M. Matteo

8. L. W. McMahon

9-10. J. Q. Miller

11. H. C. Newsom

12-13. P. T. Owen

14. J. K. Siberell

15. R. W. Weigel

16. Central Research Library

17. ER Document Management Center-RC

18. R. L. Nace, Team Leader, Fernald/Ohio Team, Office of Environmental Restoration, U.S. Department of Energy, Cloverleaf Building, EM-425, 19901 Germantown Road, Germantown, MD 20874

19-20. R. C. Sleeman, Director, Environmental Restoration Division, DOE Oak Ridge Operations Office, P.O. Box 2001, Oak Ridge, TN 37831-8541

21. J. W. Wagoner II, Team Leader, Portsmouth/Paducah/Weldon Spring Team, Office of Environmental Restoration, U.S. Department of Energy, Cloverleaf Building, EM-424, 19901 Germantown Road, Germantown, MD 20874

22. B. Issel, Community Development Director, City of Oak Ridge, P. O. Box 1, Oak Ridge, TN 37831-0001

23. H. L. Wieland, Black \& Veatch, 400 Northridge Road, Suite 350 , Atlanta, GA 30350

24-26. R. Hedrick, U.S. Army Corps of Engineers, Nashville District, P.O. Box 1070, Nashville, TN 37902

27. R. M. Meccia, Foster Wheeler Environmental Corporation, 111 Union Valley Road, Oak Ridge, TN 37830

28-29. T. E. Myrick, Science Applications International Corporation, P.O. Box 2502, Oak Ridge, TN 37831

30. J. McCollum, MK-Ferguson of Oak Ridge Company, P.O. Box 2000, Oak Ridge, TN 37831 